CENTRO UNIVERSITÁRIO FEI

STEPHAN DAUE GUIMARÃES MÜLLER

A INFLUÊNCIA DAS CONDIÇÕES OPERACIONAIS NA PONTUALIDADE DO

TRANSPORTE MARÍTIMO: simulação de um sistema de cabotagem no Brasil

São Bernardo do Campo 
STEPHAN DAUE GUIMARÃES MÜLLER

\section{A INFLUÊNCIA DAS CONDIÇÕES OPERACIONAIS NA PONTUALIDADE DO}

TRANSPORTE MARÍTIMO: simulação de um sistema de cabotagem no Brasil

Dissertação apresentada ao Centro Universitário FEI, como parte dos requisitos necessários para obtenção do título de Mestre em Engenharia Mecânica. Orientada pelo Prof. Dr. Fábio Lima.

São Bernardo do Campo 
Müller, Stephan Daue Guimarães.

A influência das condições operacionais na pontualidade do transporte marítimo: simulação de um sistema de cabotagem no Brasil / Stephan

Daue Guimarães Müller. São Bernardo do Campo, 2021.

135 p. : il.

Dissertação - Centro Universitário FEI.

Orientador: Prof. Dr. Fábio Lima.

1. Liner Shipping. 2. Cabotagem. 3. Simulação. 4. Produtividade. I. Lima, Fábio, orient. II. Título.

Elaborada pelo sistema de geração automática de ficha catalográfica da FEI com os dados fornecidos pelo(a) autor(a). 
Título do Trabalho: A influência das condições operacionais na pontualidade do transporte marítmo simulação de um sistema de cabotagem no Brasil.

Área de Concentração: Produção

Orientador: Prof. Dr. Fábio Lima

Data da realização da defesa: $14 / 12 / 2020$

\section{ORIGINAL ASSINADA}

\section{Avaliação da Banca Examinadora:}

A banca examinadora considerou o trabalho aprovado, por unanimidade. Algumas correções no texto serão necessárias, mas não há alterações técnicas. O trabalho teve boa avaliação pela banca e tem potencial para gerar uma publicação em periódico científico.

São Bernardo do Campo,

\section{MEMBROS DA BANCA EXAMINADORA}

Prof. Dr. Fábio Lima

Prof. Dr. Wilson de Castro Hilsdorf

Prof. Dr. Daniel de Oliveira Mota
Ass.:

Ass. :

Ass. :

A Banca Julgadora acima-assinada atribuiu ao aluno o seguinte resultado:

APROVADO $\square \quad$ REPROVADO

\section{VERSÃO FINAL DA DISSERTAÇÃO}

APROVO A VERSÃO FINAL DA DISSERTAÇÃO EM QUE FORAM INCLUÍDAS AS RECOMENDAÇÕES DA BANCA EXAMINADORA
Aprovação do Coordenador do Programa de Pós-graduação 
Dedico este trabalho à minha amada esposa Thais, principal fonte de inspiração, que me auxiliou desde antes do início desta graduação até a entrega final, me apoiando e incentivando sempre. 


\section{AGRADECIMENTOS}

Agradeço primeiramente a Deus, pela vida que me foi concedida e por todas as oportunidades de crescimento que me foram oferecidas ao longo desta jornada, dentre as quais este trabalho foi não somente um grande desafio, como também uma enorme realização.

Agradeço aos meus pais por todo o carinho, zelo, amparo, por me ajudarem em momentos difíceis, por me proporcionarem as primeiras experiências da minha vida e por me incentivarem a buscar sempre o melhor para mim.

Agradeço especialmente à minha amada esposa Thais Lourenço, luz da minha vida $\mathrm{e}$ minha maior fonte de inspiração. Uma pessoa mais do que especial, que faz com que eu busque a melhor versão de mim, me incentivando e apoiando. Minha companheira de todos os momentos, foi fundamental durante diversas etapas deste trabalho, seja com ideias incríveis, ou me auxiliando com a revisão do texto, ou ainda apenas me incentivando e me mantendo motivado a seguir adiante, mesmo nos momentos em que me julguei inapto a concluir esta composição.

Agradeço ao corpo docente da FEI, pelos ensinamentos transmitidos ao longo do programa e à tutoria dos professores e orientadores de cada disciplina. Agradeço também ao Prof. Dr. Fábio Lima por aceitar o desafio de me orientar na etapa final do meu projeto, conduzindo minhas ações para a bem sucedida finalização do mesmo.

Direciono um profundo agradecimento ao Prof. Dr. Alexandre Augusto Massote, um professor brilhante que aceitou o desafio de orientar este projeto, delimitando a alçada dele, dentro de um mar de possibilidades. Com ele, aprendi os pormenores da simulação e do software utilizado neste trabalho, desde o básico ao mais avançado, inclusive recorrendo a artifícios essenciais, que foram peças-chave para a realização desta simulação. Quando me afastei da instituição, atendendo a um projeto de grande importância para minha carreira e minha vida, me auxiliou, mesmo com as dificuldades de conciliação de fuso horário, a concluir etapas requeridas pelo programa. Sem o professor Massote, este projeto definitivamente não seria uma realidade e, mesmo que, por motivos alheios à nossa vontade, nossa relação orientador-aluno tenha sido abruptamente interrompida, este trabalho é não somente meu, como dele também. Mais uma vez, obrigado professor!

Agradeço também à Belge Consultoria, que abraçou a ideia deste projeto, acreditando e me apoiando, inclusive concedendo acesso pleno ao software Promodel, do qual é representante no Brasil. 
Agradeço ao Alexandre Ávila e ao Renato Coelho, meus líderes na empresa Aliança, que desde o início acreditaram no potencial deste trabalho, recomendando minha participação no curso de mestrado. Também agradeço a meus companheiros Walter Volpini, Marcos Soares e Otávio Alves pelas valiosas informações e ensinamentos que me foram enviados ao longo do trabalho. Por fim, estendo meu agradecimento ao Gustavo Costa, um dos líderes mais inteligentes e inspiradores com quem tive o privilégio de trabalhar e que gentilmente cedeu sua bibliografia de estudo nesta mesma área, contendo diversas contribuições valiosas para esta dissertação.

A todos aqueles que direta ou indiretamente contribuíram para a realização deste trabalho, do fundo do meu coração, muito obrigado! 
"O tempo é muito mais valioso do que o dinheiro. Planejar o nosso tempo é a coisa mais importante a se fazer" 


\section{RESUMO}

Dentre as modalidades existentes para o transporte de cargas, destaca-se o Liner Shipping por sua relevância ao processo de globalização e seu exponencial crescimento nas últimas décadas, consequência de seus atrativos atributos de confiabilidade, previsibilidade, elevada capacidade e baixo custo de transporte. Embora pontualidade também seja considerada como característica do Liner Shipping, dados apontam que isto não têm sido observado na prática, especialmente em mercados subdesenvolvidos, tema abordado em numerosos trabalhos acadêmicos nesta área.

No Brasil, a navegação de cabotagem exerce um papel fundamental à logística nacional ao oferecer uma alternativa viável e eficaz ao modal rodoviário, o principal meio utilizado neste país. Todavia, devido à precária infraestrutura portuária e à baixa eficiência dos principais terminais, há elevado custo operacional e baixa confiabilidade dos serviços.

Para avaliar como as condições operacionais dos portos brasileiros afetam o planejamento estratégico e tático de um serviço de Liner Shipping designado à Cabotagem, elaborou-se um modelo de simulação a eventos discretos, no qual foi estudado o serviço de uma grande empresa nacional ao longo de um ano e os dados obtidos após a simulação foram confrontados com o planejamento determinístico pré-definido pela companhia.

Os resultados mostram diversas disrupções na pontualidade do serviço, obrigando a companhia a variar a velocidade de seus navios, muitas vezes de maneira pouco atrativa financeiramente. Visualizou-se, ainda, algumas escalas com dados sub- ou superdimensionadas, interferindo na qualidade da prestação e adicionando custos desnecessários ao sistema. Por fim, identificou-se alterações necessárias a determinado planejamento, a fim de melhorar sua pontualidade.

Palavras-chave: Liner Shipping, Cabotagem, Simulação, Produtividade. 


\begin{abstract}
Among the available cargo transport modes, Liner Shipping can be highlighted due to its importance to the globalization process and the exponential growth witnessed along the last decades, as effect of the attractive attributes of reliability, predictability, high capacity and low overall cost. Although punctuality is also considered as default in Liner Shipping, past data points to a different reality, especially on developing countries, a subject approached in several research in the area.

In Brazil, Cabotage plays a significant role to the national logistics landscape, by adding a viable and efficient alternative to the road transport, the country's main transport mode. However, due to poor port infrastructure and low efficiency from the major terminals, there are high operating cost and low schedule reliability.

To evaluate how Brazilian port's operational conditions affect strategic and tactical planning of a Cabotage Liner Shipping service, a discrete-event simulation model has been developed, aiming at the cabotage service of a large Brazilian shipping company over a year and the outcome data of the simulation were crosschecked against the company's preestablished deterministic proforma.

The results show several reliability issues, forcing the company to take speed variation countermeasures, which might not be the most financially attractive scenario. Another insight regards to under- or overstated variables in some port calls, leading to bad service quality as well as unnecessarily increasing the system costs. Ultimately, some necessary proforma changes have been identified, in order to enhance its reliability.
\end{abstract}

Keywords: Liner Shipping, Cabotage, Simulation, Productivity 


\section{LISTA DE ILUSTRAÇÕES}

Figura 1 - Sistema de Cabotagem aplicado no Brasil......................................................... 25

Figura 2 - Utilização em sistemas de Longo Curso .............................................................. 40

Figura 3 - Utilização em sistemas de Cabotagem ................................................................. 41

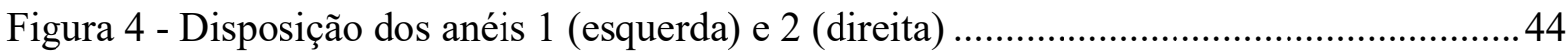

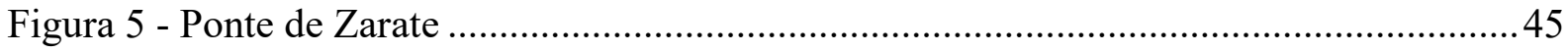

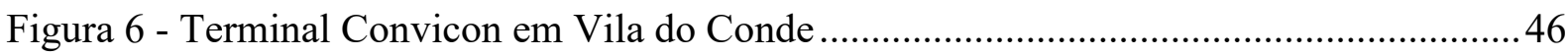

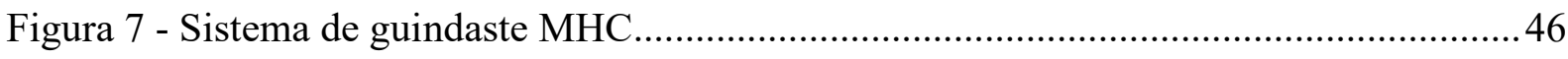

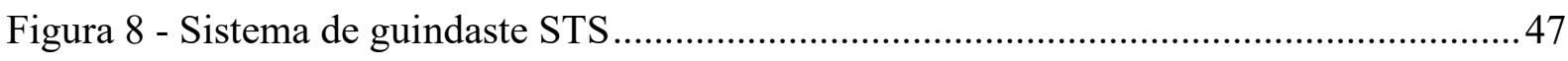

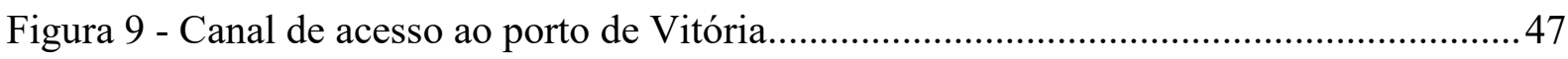

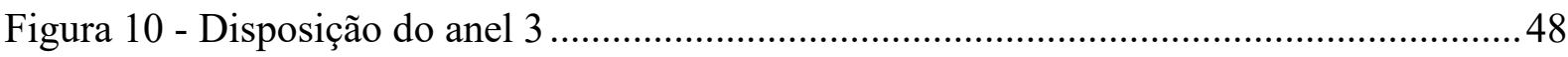

Figura 11 - Disposição dos anéis 4 (esquerda) e 5 (direita) ...................................................... 48

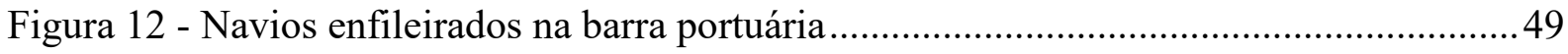

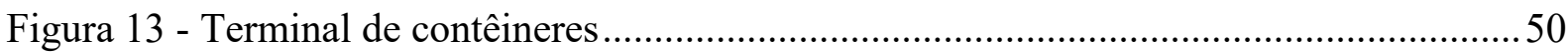

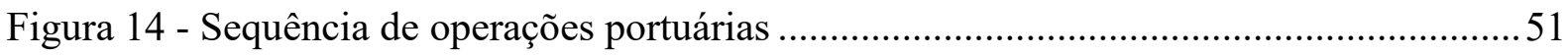

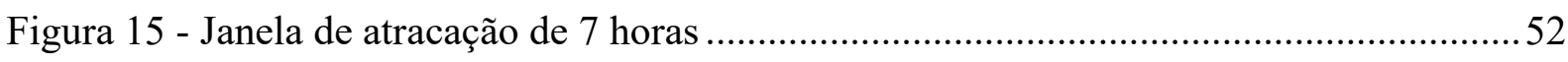

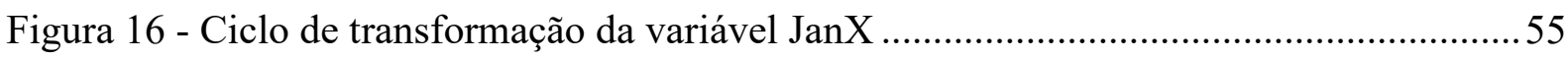

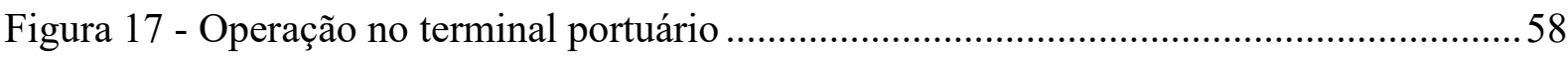

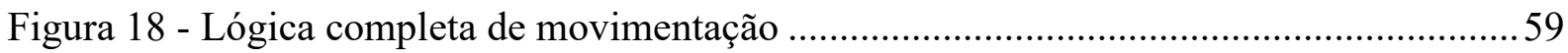

Figura 19 - Histograma da variação do tempo de operação $(\mathrm{h})$................................................... 72 


\section{LISTA DE TABELAS}

Tabela 1 - Critérios que influenciam na pontualidade do transporte marítimo .......................27

Tabela 2 - Subcritérios que influenciam na pontualidade do transporte marítimo...................28

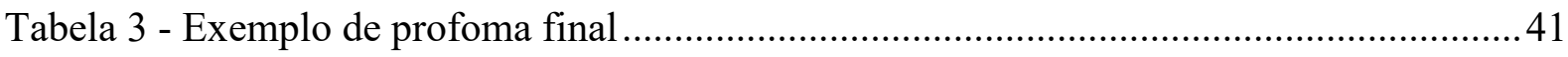

Tabela 4 - Resumo do Serviço de Cabotagem com 5 anéis...................................................... 43

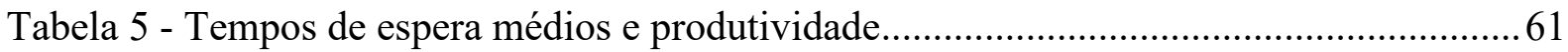

Tabela 6 - Consumo de combustível (ton/h) versus velocidade versus altura do calado ..........63

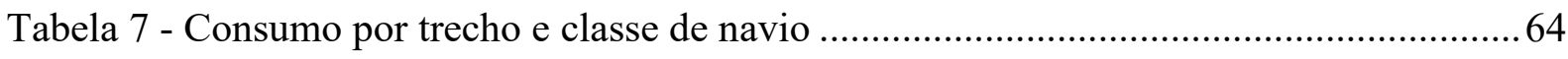

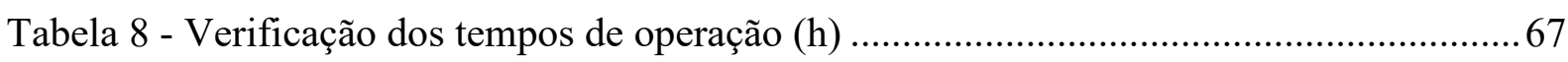

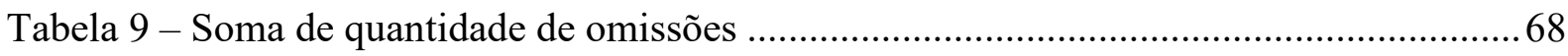

Tabela 10 - Verificação de consumos e distâncias ...................................................................... 69

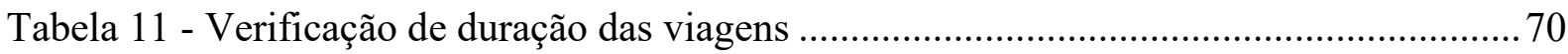

Tabela 12 - Validação dos parâmetros de entrada ..................................................................... 71

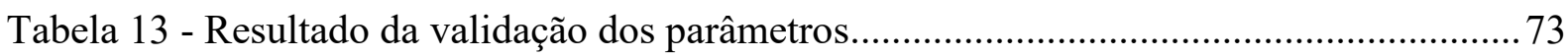

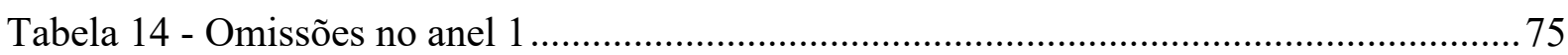

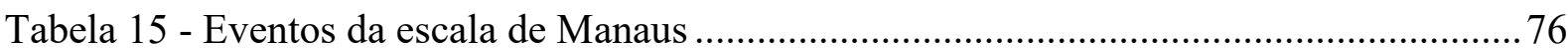

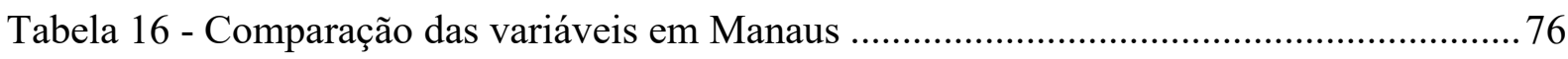

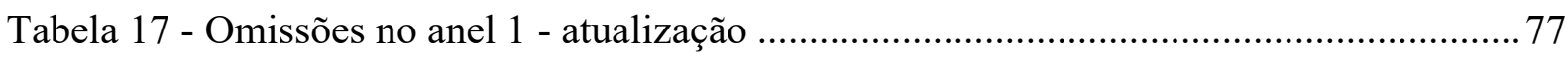

Tabela 18 - Redução de consumo (ton) devido à menor velocidade ........................................ 77

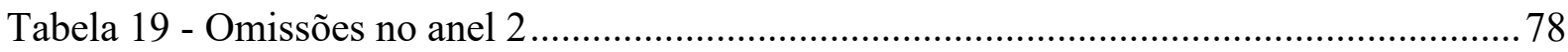

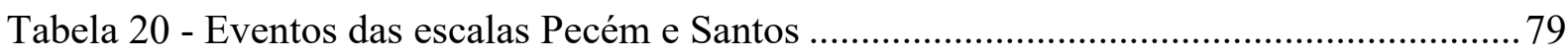

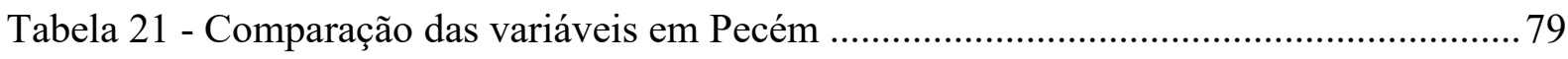

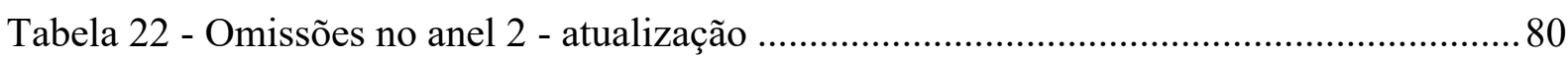

Tabela 23 - Maior consumo decorrente da recuperação de programação ................................ 81

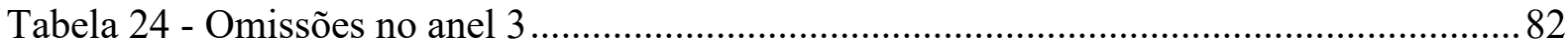

Tabela 25 - Comparação de variáveis em Rosario .................................................................... 83

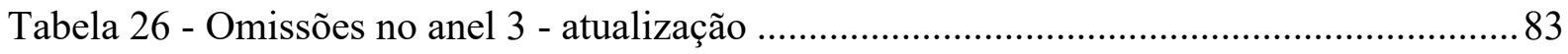

Tabela 27 - Perda da viagem Nordamelia 10 e 11 norte .......................................................... 84

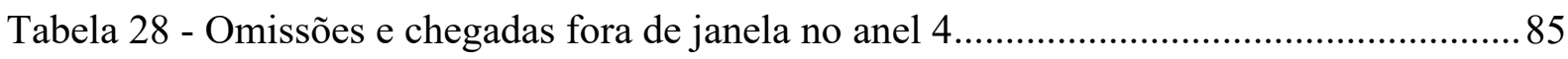

Tabela 29 - Escalas na Santos Brasil com elevado tempo de operação ................................... 86

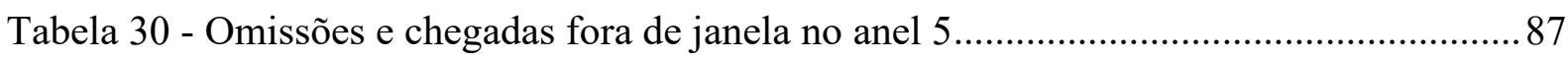

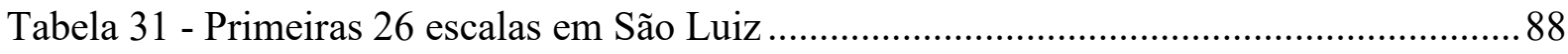

Tabela 32 - Primeiras 26 escalas em Pecém e Vila do Conde................................................ 89 
Tabela 33 - Tempo necessário para finalização de viagens no anel 5. .90 


\section{LISTA DE ABREVIATURAS E SIGLAS}

IMO International Maritime Organization

FAHP Fuzzy Analytic Hierarchy Process

ADE Adaptive Differential Evolution

TEU Twenty-foot Equivalent Unit

CNT Confederação Nacional do Transporte

ANTAQ Agência Nacional de Transportes Aquaviários

MHC Mobile Harbour Crane

STS Ship-to-Shore Crane

TVV Terminal de Vila Velha

FPLP $\quad$ First Pick Last Pick

MS Microsoft

N Direção Norte

S Direção Sul

BTP Brasil Terminal Portuário

SBSA Santos Brasil Participações

EMB Embraport

SECAB Sebastião Caboto

PECAB Pedro Álvares Cabral

FERMA Fernão de Magalhães

AMVES Américo Vespúcio

SOLIS João de Solis

BARDI Bartolomeu Dias

VIPIN Vicente Pinzon

MOSAR Monte Sarmiento

ALMAN Aliança Manaus

NORDA Nordamelia

LOGPA Log-In Pantanal

ALLEB Aliança Leblon

Tecon Terminal de contêineres

Mov. Movimentos realizados com os contêineres no terminal

Prod. Produtividade

Cons. Consumo de combustível 
$\mathrm{mn}$

h

ton

ton $/ \mathrm{h}$
Milha náutica

Horas

Tonelada

Tonelada por hora 


\section{SUMÁRIO}

1 INTRODUÇÃO ............................................................................................................................ 16

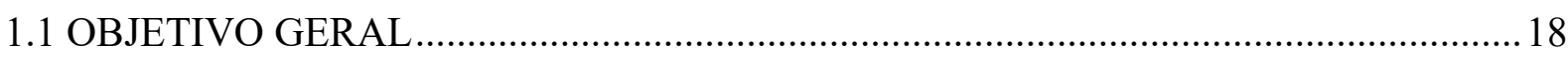

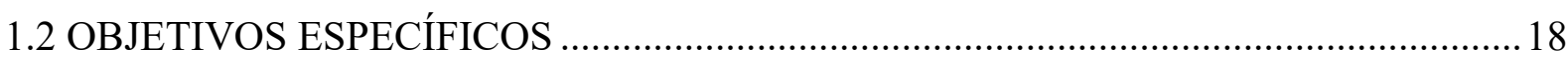

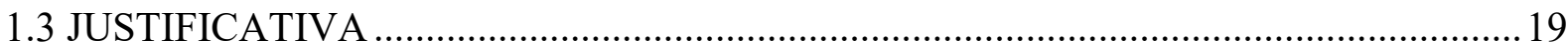

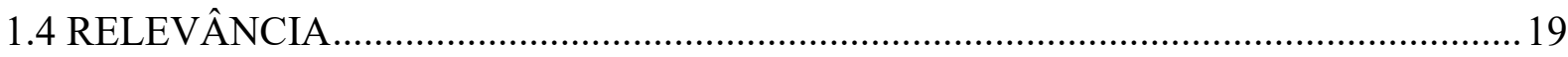

2 FUNDAMENTAÇÃO TEÓRICA.....................................................................................21

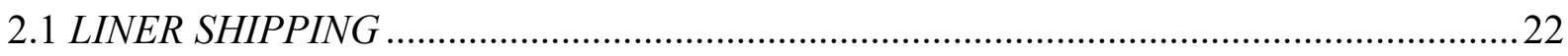

2.2 PONTUALIDADE NO TRANSPORTE MARÍTIMO_..........................................................

2.3 PRODUTIVIDADE E MELHORIA DO PLANEJAMENTO DE ESCALAS ...................28

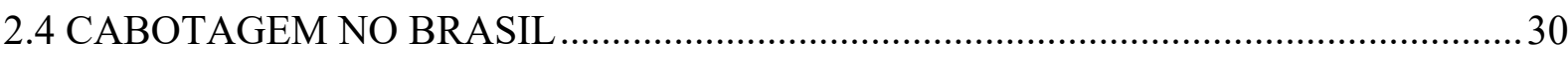

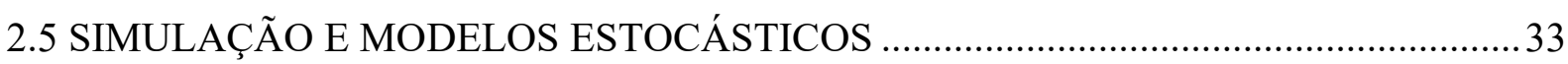

3 DESENVOLVIMENTO....................................................................................................36

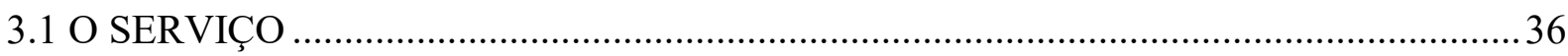

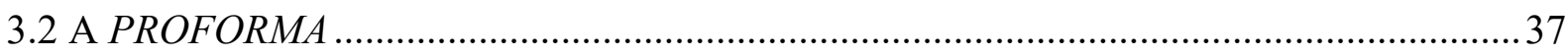

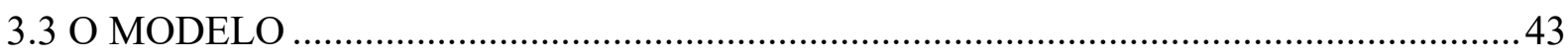

3.3.1 Chegada, Atracação e Desatracação................................................................................. 49

3.3.2 Janelas de Atracação .......................................................................................................... 51

3.3.3 Operação e Produtividade Portuária..............................................................................55

3.3.4 Dados de Entrada ...............................................................................................................59

3.3.5 Consumo de Combustível ....................................................................................... 61

4 SIMULAÇÃO E RESULTADOS ……………………….........................................................65

4.1 PRIMEIRA SIMULAÇÃO E VALIDAÇÃO DO MODELO …………………………….... 65

4.2 SEGUNDA SIMULAÇÃO E VALIDAÇÃO DOS PARÂMETROS ..................................70

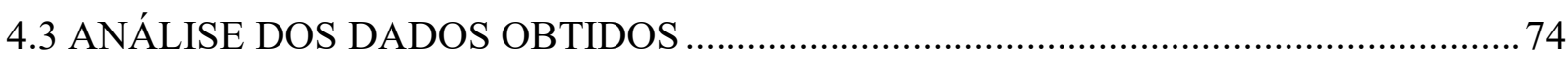

4.3.1 Anel 1 ................................................................................................................................. 74

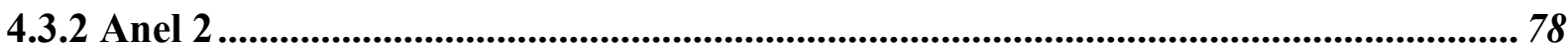

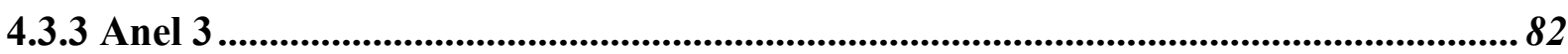

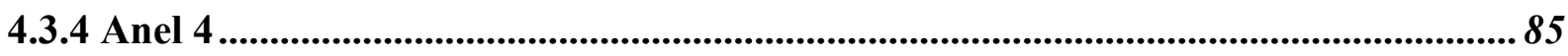

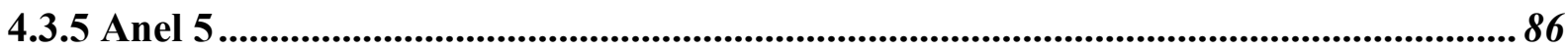


5 CONCLUSÃO E SUGESTÕES .....................................................................................92

6 REFERÊNCIAS ..................................................................................................................94

APÊNDICE A - PROFORMAS ...........................................................................101

APÊNDICE B - JANELAS DE ATRACAÇÃO..................................................................105

APÊNDICE C - DISTRIBUIÇÕES ESTATÍSTICAS .......................................................106

APÊNDICE D - MODELO PROMODEL.........................................................................108

APÊNDICE E - LÓGICA COMPUTACIONAL ............................................................109 


\section{INTRODUÇÃO}

"A inovação é o que distingue um líder de um seguidor."

(Steve Jobs)

O transporte marítimo de carga conteinerizada é nitidamente um mercado caracterizado pela elevada concorrência entre os armadores e a escassa distinção na prestação de serviços, o que estabelece uma série de desafios quanto à fidelização de clientes e, portanto, provisão estável, contínua e crescente de receita para as empresas (TING; TZENG, 2004).

A introdução do uso de contêineres no modal marítimo inicia-se na década de 50 do séc. $\mathrm{XX}$, como uma tentativa, muito bem sucedida, de acelerar o embarque e desembarque das mercadorias, transportadas unitariamente e soltas até então (MAYO; NOHRIA, 2005). O uso dos contêineres contribuiu não apenas para a eficiência nas operações dentro dos portos, como também promoveu uma revolução nas relações comerciais e, consequentemente, no desenvolvimento da economia global.

Desde 1980, o volume movimentado de carga conteinerizada aumentou cerca de 1700\%, passando de 102 milhões de toneladas embarcadas para 1,72 bilhão em 2016 (UNCTAD, 2017), um crescimento médio ponderado de aproximadamente $8 \%$ ao ano. Ademais, quando comparado a outros tipos de transporte marítimo, como granel líquido e sólido, o transporte de carga conteinerizada também demonstra significativo aumento de participação, passando de 3\% em 1980 para aproximadamente 17\% em 2016, ratificando a importância deste segmento para a logística global.

As características de economia de escala; alta confiabilidade de planejamento; baixos custos, riscos e tempo reduzido no transporte indicadas por Notteboom (2006) ajudam a explicar o exponencial aumento do volume transportado por este modal, ao longo dos últimos 40 anos, atendendo às demandas por prazos eficientes a custos reduzidos inerentes à globalização e colocando este modal como o maior em termos de volume para transporte de cargas no mundo (SALLEH et al., 2017).

Segundo Ting e Tzeng (2004), a alta competitividade deste setor resulta em uma restrição para o aumento dos fretes que, aliada aos elevados custos de posicionamento de contêineres vazios e na crescente demanda por investimentos em navios e equipamentos, dificulta a geração significativa de lucros, estimulando os armadores a buscarem soluções 
operacionais eficientes e inovadoras que, consequentemente, aumentem sua lucratividade e posicionamento dentro do mercado.

Dentre estas soluções, destaca-se a importância da regularidade e pontualidade na prestação de serviço, pois a falta destas não somente gera impactos negativos ao armador como também a seus clientes (CHUNG; CHIANG, 2011). Além disto, empresas que apresentam soluções inovadoras em suas programações e que zelam pelo cumprimento de prazos, possuem um notável diferencial diante de seus concorrentes, como é observado na empresa Maersk, armador dinamarquês com destacada presença comercial global, através de seu arrojado serviço Daily Maersk (ZHANG; LAM, 2014, 2015).

Embora os transportadores marítimos reivindiquem que o Liner Shipping é pontual quanto aos prazos de transporte das cargas, dados históricos mostam uma realidade diferente, com atrasos na entrega em praticamente todos os serviços disponíveis (VERNIMMEN; DULLAERT; ENGELEN, 2007), tornando esta temática uma das mais estudadas nos últimos anos (SALLEH et al., 2017). Chung e Chiang (2011) levantaram os principais fatores que influenciam os atrasos, com destaque para a programação incorreta de janelas de atracação, planejamento inadequado de escalas e planos de transbordo ineficientes. Meijer, Mulder e Van Oosterom (2016) destacam que a alocação de reservas de tempo inadequados também contribui para esta deficiência, ao passo que Notteboom (2006) enfatiza o problema da baixa produtividade dos terminais portuários e do potencial congestionamento nos portos.

Neste contexto, faz-se conexão à realidade marítima brasileira e suas peculiaridades. Com 14\% de participação na matriz de transporte de carga nacional (CONFEDERAÇÃO NACIONAL DO TRANSPORTE, 2018), a Cabotagem é marcada pela insuficiente produtividade em seus terminais portuários, proveniente de um déficit de infraestrutura, com moderada perspectiva de investimentos futuros (DAGANZO et al., 2018; LÓPEZBERMÚDEZ; FREIRE-SEOANE; GONZÁLEZ-LAXE, 2019; MEDEIROS et al., 2015; SILVEIRA; JÚNIOR, 2013). A crescente demanda observada neste modal agrava ainda mais a situação, contribuindo para um aumento da probabilidade de atrasos, uma realidade bastante desfavorável ao potencial de crescimento desta modalidade no Brasil.

A literatura acerca do transporte marítimo é vasta, explorando os três níveis de tomada de decisão propostas por Pesenti (1995): estratégico, tático e operacional. Os problemas relacionados à pontualidade e regularidade do serviço são, usualmente, abordados no nível tático, juntamente com os problemas de otimização de velocidade, implantação de frota e determinação de frequências (MENG et al., 2014). 
A maioria dos estudos nesta temática adotam abordagem determinística (AYDIN; LEE; MANSOURI, 2017; CHRISTIANSEN; FAGERHOLT, 2002; LI; QI; SONG, 2016; MEIJER; MULDER; VAN OOSTEROM, 2016; MENG et al., 2014) ou exploratória (CHUNG; CHIANG, 2011; SALLEH et al., 2017), mesmo que significativa parcela das variáveis relevantes aos modelos sejam de caráter aleatório, como demanda de carga, condições climáticas, eficácia das operações portuárias ou fila de atracação nos portos, muitas das quais, não estão sob gestão do armador (CHUNG; CHIANG, 2011; NOTTEBOOM, 2006). A bibliografia atual, embora rica em modelos otimizantes, apresenta escassos trabalhos abordarando o assunto através da simulação estocástica, que constitui uma ferramenta importante neste tipo de problema, ferramenta esta defendida inicialmente por Pesenti (1995). Além disto, infelizmente, boa parcela das empresas de transporte marítimo adota postura conservadora quanto ao uso de métodos computacionais, limitando a implementação e validação de novas metodologias científicas (MENG et al., 2014).

No âmbito da navegação nacional, os principais estudos realizados têm caráter exploratório, sendo raros aqueles conduzidos através de métodos computacionais e, quando existentes, são limitados a escopos regionais, sem aplicação em maior escala.

Visualiza-se, portanto, uma contribuição, tanto à academia, quanto à indústria marítima, para se desenvolver e implementar um modelo de simulação computacional que, a partir de premissas previamente estabelecidas nos níveis estratégico (tamanho e capacidade da frota) e tático (portos escalados, sequência e frequência do serviço), possibilitará a análise antecipada de potenciais atrasos e, com isso, fomentará a tomada de decisões mais eficazes .

\subsection{OBJETIVO GERAL}

A partir de simulações computacionais, verificar a conformidade dos planos estratégico e tático definidos pela gestão de uma companhia de navegação aos requerimentos de pontualidade e regularidade de um serviço de cabotagem brasileira.

\subsection{OBJETIVOS ESPECÍFICOS}

- Desenvolver um modelo de simulação holística para os serviços de cabotagem de um armador nacional; 
- Validar as decisões estratégica e tática anteriormente definidas, para antever possíveis problemas e corrigi-los.

\subsection{JUSTIFICATIVA}

A maioria dos trabalhos relacionados ao tema visa à otimização do tempo de escalas, chegada dos navios, até mesmo elaboração de uma programação mais eficaz, mas sempre com uso de modelos otimizantes, que tem característica determinística. Estes modelos, quando aplicados isoladamente, introduzem um risco potencial à garantia de pontualidade por eles proposta, por não considerarem as variabilidades inerentes à operação, fazendo relevante o uso da simulação computacional como ferramenta de validação das premissas outrora estabelecidas, seja empiricamente ou a partir de modelos otimizantes, em hierarquias mais elevadas do processo decisório.

Além disto, a literatura acerca do modal marítimo pouco aborda a Cabotagem brasileira, um setor de vital importância para a economia nacional e que apresenta grande crescimento ao longo da última década, ao mesmo tempo que sofre com baixos investimentos para expansão e atualização. Os poucos trabalhos visualizados na literatura abordam o assunto de maneira qualitativa, estabelecendo uma lacuna para o aprofundamento de estudos quantitativos neste setor.

\subsection{RELEVÂNCIA}

Este trabalho visa a melhoria na programação de escalas e serviços de logística marítima ao tentar antever se um serviço estabelecido terá sua pontualidade preservada, ou enfrentará atrasos subsequentes, por não estarem bem ajustados à realidade dos portos e demandas locais.

Em outras palavras, o modelo proposto contribui para que os serviços sejam melhorados de forma ativa, ajustando-os antecipadamente com a finalidade de melhorar a previsibilidade e confiabilidade do serviço, quando este estiver em operação.

Do ponto de vista acadêmico, este estudo acrescenta à conjugação entre teoria e prática neste modal, utilizando a simulação computacional, metodologia pouco aplicada nos estudos da área, mas importante em ser capaz de lidar com variáveis aleatórias, fatores bastante sensíveis nas operações deste modal. 
Por fim, o presente trabalho desenvolve um modelo de simulação operacional aplicado a um grande e complexo serviço da cabotagem brasileira, inédito nesta literatura. Tal iniciativa não somente fomenta novas aplicações de métodos quantitativos neste modal, como também apresenta às empresas deste ramo outra opção para gestão de planejamento e logística.

\subsection{ORGANIZAÇÃO DA DISSERTAÇÃO}

Este trabalho será estruturado em 5 capítulos. O primeiro, já apresentado, refere-se à introdução ao tema, apresentação da lacuna de pesquisa e dos objetivos deste trabalho.

O capítulo 2 será dedicado à revisão da literatura existente sobre o assunto e será, para melhor organização, separado em cinco subtópicos: Liner Shipping, Pontualidade no transporte marítimo, Produtividade e melhoria do planejamento de escalas, Transporte de cabotagem no Brasil, seus desafios e oportunidades e Simulação e modelos estocásticos.

No terceiro capítulo, será desenvolvido o modelo de simulação, contendo as especificações das regras, entradas e saídas de dados, assim como o diagrama do algoritmo implementado.

O penúltimo capítulo será dedicado à análise dos resultados e, por fim, no capítulo final serão apresentadas as conclusões e sugestões de trabalhos futuros. 


\section{FUNDAMENTAÇÃO TEÓRICA}

"A mente que se abre a uma nova ideia jamais voltará ao seu tamanho original."

(Albert Einstein)

O transporte marítimo de cargas constitui um dos principais modais logísticos da atualidade, e cresce de maneira significativa anualmente, desde os anos 1980. Segundo UNCTAD (2017), a quantidade de carga transportada por este meio, somando-se todos os tipos (granel, contêiner, carga geral), quase triplicou no período entre 1980 e 2016, passando de 3,7 bilhões de toneladas transportadas a 10,3 bilhões de toneladas.

Dentre os tipos de transporte deste setor, destaca-se a movimentação de carga conteinerizada, que evoluiu consistentemente neste período, com taxa de crescimento composta de $8 \%$ ao ano e aumento de participação de $3 \%$ para $17 \%$, quando comparado aos demais tipos de transporte aquaviário.

Tamanho incremento é compreensível devido à intensificação da globalização mundial, a qual foi fundamentalmente beneficiada pela evolução deste tipo de transporte (NOTTEBOOM, 2006), com suas características de baixo custo, alta previsibilidade, capacidade e economia de escala.

Por outro lado, é um setor de capital intensivo, ou seja, que demanda constantes e elevados investimentos para manutenção e renovação de seus equipamentos (TING; TZENG, 2004), mas que tem, como principal fonte de receita, o frete relativo ao transporte de contêineres entre dois portos (WANG; MENG; DU, 2015). Desta forma, o faturamento dos armadores fica sujeito a grande volatilidade, resultado de fatores como sazonalidade, incertezas e recessos econômicos (KAVUSSANOS; VISVIKIS, 2006), marcado por elevada concorrência entre as empresas (CHUNG; CHIANG, 2011; TING; TZENG, 2004) e pouca capacidade de diferenciação dos serviços prestados (NOTTEBOOM, 2006).

Para os clientes das empresas de transporte, o serviço ideal é aquele que conduz sua carga com maior agilidade e diretamente ao seu destino final, ao passo que a elaboração de serviços demasiadamente customizados aumenta consideravelmente o já elevado custo operacional destas companhias.

Nesta conjuntura, os armadores utilizam-se de estratégias inovadoras no desenho de suas redes, sempre balanceando as demandas de seus clientes com redução custos operacionais (CALATAYUD; MANGAN; PALACIN, 2017; RAJKOVIC et al., 2015), uma vez que o êxito 
no estabelecimento de serviços velozes, pontuais e confiáveis é decisivo para o sucesso financeiro de uma companhia, pois constituem o diferencial necessário para atrair clientes e retê-los, sem diminuição dos valores de fretes.

\subsection{LINER SHIPPING}

O transporte marítimo de carga apresenta, de maneira geral, três tipos de operação: privado, tramp e liner (LAWRANCE, 1972). No primeiro, os navios são controlados pela empresa dona da carga, que o opera de maneira a transportá-la, com o menor custo possível. Segundo Ronen (1983), este tipo de navegação é bastante comum para transporte de commodities, como é o caso da empresa brasileira VALE, que opera navios do tipo mineraleiros, chamados Valemax, em 10 portos e 2 estações flutuantes atendidos pela companhia (VALE, 2019).

Já o segundo tipo de navegação, denominado tramp shipping, consiste em operações em que o dono do navio não é dono da carga, mas seleciona-a com base na rota que garante a ele maior rentabilidade (MENG et al., 2014). É um tipo de operação pouco explorado pelas empresas, devido ao elevado risco de ociosidade das embarcações. Uma exceção a esta tendência é a operação de navios frigoríficos (RONEN, 1983), que transportam cargas refrigeradas, usualmente com grandes demandas sazonais.

Por fim, denomina-se liner shipping o tipo de navegação em que as empresas estabelecem determinadas rotas com escalas fixas em determinados portos e frequência regular (MENG et al., 2014; ZERBY; CONLON, 1978). Conforme Notteboom (2006), a frequência estabelecida é, usualmente, semanal. Desta forma, há um maior balanceamento entre regularidade de embarques e volume transportado por embarque, atendendo mais satisfatoriamente à demanda de clientes por melhores tempos de trânsito. Além disto, escalas semanais permitem planejamento mais adequado junto aos terminais portuários e o estabelecimento de janelas de atracações com data e horários pré-estabelecidos (MENG et al., 2014). A movimentação de contêineres no mundo é realizada, em sua vasta maioria, através deste modelo de transporte.

Diferentemente das duas primeiras operações citadas, observa-se um comprometimento por parte dos operadores de Liner Shipping quanto à regularidade e a qualidade do serviço prestado (ZERBY; CONLON, 1978). Por outro lado, são mais vulneráveis às oscilações de demanda e, consequentemente, estão mais susceptíveis a perdas. Portanto, embora a minimização de custos ainda seja de grande importância para estas empresas, seu principal 
enfoque reside no aumento de lucratividade, resultado da prestação do serviço de transporte (RONEN, 1983).

Pesenti (1995) estabelece três níveis de tomada de decisão para empresas deste setor. A primeira, estratégica, visa à determinação do tamanho da frota, de sua capacidade e das alianças estratégicas que serão estabelecidas. Usualmente, tem um horizonte de 3 a 5 anos, chegando a 30 anos, quando se envolve aquisição de novos navios (MENG et al., 2014) e tem influência decisiva nos demais níveis, determinando seus limites para tomada de decisão. Cho e Perakis (1996) desenvolveram um modelo para determinação da frota ideal, considerando diferentes tamanhos de navios e a otimização das rotas possíveis, assim como para determinação das melhores alternativas de investimento. Já Fagerholt (1999) criou um modelo para determinação das melhores rotas e serviços para uma frota determinada utilizando a técnica do particionamento de conjuntos.

O segundo nível, tático, tem horizonte de 4 meses a 1 ano, e envolve arbítrios quanto à distribuição da frota, otimização de velocidade das embarcações e a elaboração de cronogramas. Segundo Meng et al. (2014), são problemas usualmente atrelados àqueles interpelados no nível anterior, muitas vezes com soluções síncronas, ou então com limites estabelecidos por aquela hierarquia. Perakis e Jaramillo (1991) e Jaramillo e Perakis (1991) foram pioneiros no estudo da distribuição de frota e modelamento de rede, ainda que através de um modelo de programação linear, ou seja, considerando a frota como variável contínua. Powell e Perakis (1997) complementam os estudos anteriores através de um modelo de programação inteira. Mais recentemente, foi desenvolvido um modelo de custo genérico para minimização de custos de uma empresa de navegação, através de algoritmos genéticos (ZACHARIOUDAKIS et al., 2011).

Ainda neste nível hierárquico são desenvolvidos problemas envolvendo consumo de combustível, igualmente impactantes na solução, uma vez que o consumo é drasticamente afetado com pequenas variações de velocidade (NOTTEBOOM; VERNIMMEN, 2009). Segundo Zacharioudakis et al. (2011), a relação entre velocidade e consumo de combustível aproxima-se de uma equação de terceiro grau, em que o consumo varia em relação ao cubo da velocidade de navegação. Wang e Meng (2012b) obtiveram, através de dados históricos, expoentes variando entre 2.7 e 3.3, confirmando a correlação teórica. O consumo de combustível também é fator decisivo na emissão de poluentes e a redução da velocidade de navegação é uma prática saudável tanto economicamente, quanto ecologicamente (KONTOVAS; PSARAFTIS, 2011). Os autores apontam, inclusive, para fatores que 
incentivam esta redução, como a volatilidade de preço do combustível e a necessidade de se usar combustíveis mais caros em zonas de emissões controladas.

Para atender a nova regulamentação de emissões estabelecida pela Organização Marítima Internacional (International Maritime Organization - IMO), conhecida como IMO 2020, sem modificações nos navios, faz-se necessário o uso de combustíveis com baixo teor de enxofre em sua composição, que tem preço mais elevado do que aquele consumido até então (HALFF; YOUNES; BOERSMA, 2019). Este significativo aumento torna ainda mais relevante a otimização de velocidade de navegação.

Por fim, as tomadas de decisões de âmbito operacional se resumem à escolha e roteamento de cargas e reprogramação do transporte por motivos de contingência. São problemas com horizontes curtos, geralmente de 1 a 4 semanas (PESENTI, 1995) e, geralmente, são menos estruturados do que as hierarquias que o precedem. Embora sejam problemas que lidam profundamente com as diversas aleatoriedades existentes no cotidiano destas empresas, são encontrados poucos trabalhos com esta abordagem na literatura.

A maior parte dos trabalhos desenvolvidos no âmbito operacional tem enfoque na escolha de carga e no Revenue Management. Disrupções operacionais e suas soluções, embora comuns e causadas por diversos fatores (VERNIMMEN; DULLAERT; ENGELEN, 2007) são pouco exploradas na literatura. Um dos poucos exemplares se trata do modelo matemático que visa a recuperação das programações de escalas em atraso aplicado em casos reais do armador dinamarquês Maersk Line (BROUER et al., 2013), com um resultado bastante promissor.

Em Liner Shipping, entende-se por sistema ou serviço o conjunto de rotas estabelecidas, abrangendo portos com escalas fixas e regulares, atendidas por um ou mais navios (MENG et al., 2014). Neste conjunto, denomina-se anel cada rotação que individualmente compõe o sistema. Na figura 1, visualiza-se um exemplo ilustrativo de sistema de navegação de Cabotagem na costa brasileira, composto por dois anéis. 
Figura 1 - Sistema de Cabotagem aplicado no Brasil

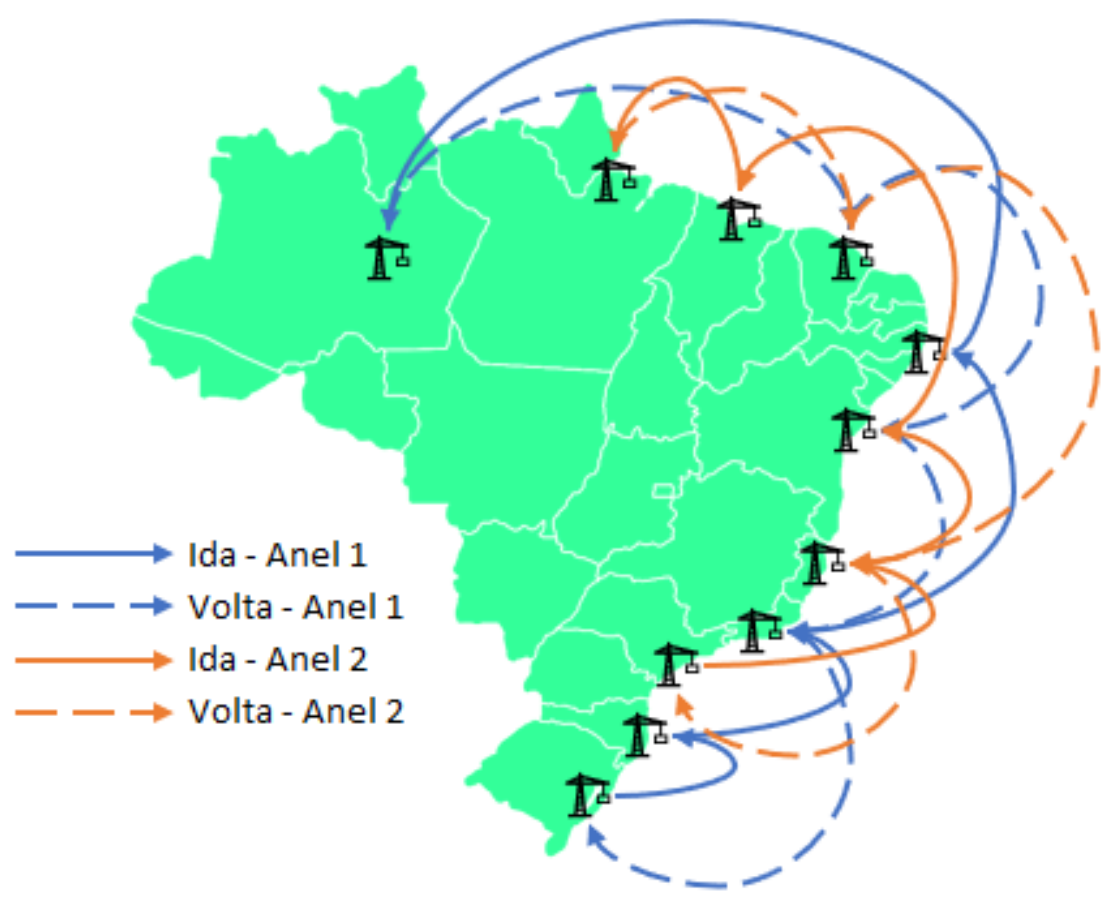

Fonte: Autor

Diversos são os fatores levados em consideração durante a elaboração de um sistema de navegação, dentre eles, demanda de clientes, frota disponível e portos escalados com suas respectivas condições operacionais (AGARWAL; ERGUN, 2008). Segundo Pesenti (1995), o planejamento de um serviço de navegação é realizado em três etapas hierárquicas: estratégica, tática e operacional, das quais as duas primeiras são realizadas durante a fase de concepção do serviço, enquanto a última é conduzida durante a operação e manutenção.

No primeiro nível hierárquico, o estratégico, são determinados tamanho de frota, capacidade de seus navios, alianças estratégicas e o desenho da malha a ser atendida (MENG et al., 2014). Já na segunda etapa, realiza-se a alocação dos navios nas malhas, determinam-se frequência de escalas e velocidade de navegação e, ainda, estabelece-se a programação do serviço completo, denominada proforma. A terceira e última, pouco relevante durante o planejamento do serviço, é a etapa na qual se concentra a escolha de carga para embarque e a reprogramação de escalas, operações cotidianas baseadas no serviço já implementado.

A proforma consiste no planejamento final do serviço, onde estão contidas todas as informações pertinentes à operação do sistema, como distâncias, velocidades de navegação, arranjos de janelas de atracação, assim como os navios assinalados e suas capacidades 
(KOENEN, 2017). É o produto final da etapa tática, sendo elaborada uma proforma por anel e caracteriza o sistema em sua forma teórica/ideal.

Com o objetivo de se avaliar a adequação de um serviço planejado aos requerimentos de pontualidade e nível de prestação de serviço, ao longo de um período de um ano, foi elaborado um modelo de simulação estocástica, levando em consideração variáveis como demanda de carga, produtividade portuária, atrasos inerentes às operações portuárias e condições climáticas. No modelo foram acrescentados, ainda, parâmetros para o cálculo de consumo de combustível, custo mais oneroso na operação de um navio e que é diretamente afetado por disrupções no planejamento, assim como modificações no planejamento.

Variadas metodologias são utilizadas para elaboração das etapas estratégica e tática, seja através do uso dos modelos determinísticos encontrados na literatura (MENG et al., 2014), ou manualmente, a partir da experiência dos profissionais da área (AGARWAL; ERGUN, 2008). Este trabalho tem o objetivo verificar a conformidade de um serviço outrora planejado quanto aos parâmetros de pontualidade e eficiência desejados pelo armador, considerando a dispersão estatística das variáveis ao longo do período de análise. Desta forma, não serão utilizados, no presente estudo, modelos que enderecem as estapas estratégica e tática. Em vez disto, utilizarse-á uma proforma existente, estabelecida pela empresa, e serão testadas as condições operacionais oriundas de sua aplicação, por meio de simulação computacional.

\subsection{PONTUALIDADE NO TRANSPORTE MARÍTIMO}

É notória a importância do transporte marítimo na economia global. Conforme Notteboom (2006), a globalização só é possível devido ao desenvolvimento deste modal de transporte, devido às suas características de baixo custo, alta previsibilidade, capacidade e economia de escala. Por isso, o modal apresentou crescimento bastante acelerado nos últimos anos, criando um cenário de alta competitividade. Devido à baixa capacidade de diferenciação da prestação de serviço entre os armadores, alguns detalhes podem ser fundamentais para a fidelização de clientes.

Neste contexto, a capacidade dos armadores em manterem suas programações de entregas intactas tem grande importância devido aos custos adicionais gerados tanto para a transportadora quanto para seus clientes, reais ou intangíveis (MENG et al., 2014) e, por isso, se consolidou como um dos temas de pesquisa e desenvolvimento mais importantes nos últimos anos (SALLEH et al., 2017). Vernimmen, Dullaert e Engelen (2007) apontam que há sempre 
um impacto negativo para cada um dos principais envolvidos em um transporte marítimo, a saber, transportadora, operador portuário, transportador rodoviário, embarcador e destinatário. Indiretamente, o consumidor final também é afetado, uma vez que disrupções logísticas afetam o preço final dos produtos comercializados.

Para o armador, o custo adicional relativo ao dia perdido se traduz em despesas com combustível, tripulação e majoritariamente custos de capital. Notteboom (2006) mostra ainda que gastos adicionais podem ser vislumbrados, dependendo da estratégia adotada para minimização dos atrasos já estabelecidos.

Analisando-se pela perspectiva do cliente, os impactos são principalmente relacionados ao risco de parada da fábrica por atraso de matéria prima, para o qual é estabelecido a caráter de contingência um custoso estoque de segurança (VERNIMMEN; DULLAERT; ENGELEN, 2007). Notteboom (2006), por sua vez, analisa que, dependendo do valor agregado da mercadoria embarcada, o custo de capital de um dia de atraso é suficiente para ultrapassar o custo diário de afretamento de um navio de médio porte.

Embora seja difundido que o modal marítimo tem grande confiabilidade no que diz respeito a pontualidade, Vernimmen, Dullaert e Engelen (2007) afirmam que grande parte dos prestadores de serviço não atinge perfeita harmonia entre o prazo de entrega estimado e o realizado. Para melhor entender as razões pelas quais os atrasos acontecem e determinar estratégias adequadas para mitigação dos mesmos, Chung e Chiang (2011) utilizam-se do método FAHP (Fuzzy Analytic Hierarchy Process) para pesquisar tais motivos e o grau de gerência da empresa sobre estes. Os resultados deste estudo, resumidos na tabela 1, mostram que, dentre quatro fatores previamente estabelecidos (estratégias de operações, estafe da empresa de navegação, gestão dos processos pelo armador e condições portuárias), a gestão dos processos é a que obteve maior fator de contribuição, seguida pelas estratégias de operações adotadas na companhia.

Tabela 1 - Critérios que influenciam na pontualidade do transporte marítimo

\begin{tabular}{cccc}
\hline Critério & Descrição & Influência & Ranking \\
\hline O1 & Estratégias de operações & 0.211 & 2 \\
O2 & Estafe da empresa de navegação & 0.138 & 3 \\
O3 & Gestão dos processos pelo armador & 0.589 & 1 \\
O4 & Condições portuárias & 0.061 & 4 \\
\hline
\end{tabular}

Fonte: Chung e Chiang, 2011 
Analisando os subcritérios utilizados para definição do peso de cada critério, apresentados na tabela 2 , verifica-se que o planejamento adequado de escalas, de suas janelas e berços de atracação, bem como o adequado arranjo de transbordo de cargas são os fatores mais influentes para a ocorrência de atrasos em serviços de navegação. Este fato reitera a importância do correto planejamento estratégico do armador, que tem papel decisivo na criação de serviços confiáveis. É importante também destacar a eficiência dos terminais portuários pois, embora isoladamente tenha um peso modesto em comparação aos demais fatores, é um fator decisivo na escolha do terminal e impacta diretamente na alocação de janelas de atracação. Vale observar e ressaltar que o estudo foi conduzido na Ásia, onde os terminais portuários são muito eficientes e tecnológicos (DIAS, 2013), realidade bastante divergente da brasileira.

Tabela 2 - Subcritérios que influenciam na pontualidade do transporte marítimo

\begin{tabular}{ccccc}
\hline Critério & Sub-critério & Description & Influência & Ranking \\
\hline \multirow{2}{*}{01} & 011 & Planejamento adequado de escalas & 0.155 & 3 \\
& 012 & Adoção de Chase Strategy & 0.040 & 7 \\
& 013 & Investimentos em terminais dedicados & 0.016 & 10 \\
\hline \multirow{2}{*}{02} & 021 & Engajamento dos funcionários & 0.024 & 9 \\
& 022 & Habilidade de coordenação de fatores externos & 0.042 & 6 \\
& 023 & Gerenciamento de pessoal eficiente & 0.072 & 5 \\
\hline \multirow{2}{*}{03} & 031 & Alocação apropriada de janelas de atracação & 0.320 & 1 \\
& 032 & Planejamento antecipado de berço de atracação & 0.074 & 4 \\
& 033 & Esquematização de transbordos & 0.194 & 2 \\
\hline \multirow{2}{*}{04} & 041 & Congestionamento dos acessos aos terminais & 0.009 & 12 \\
& 042 & Alocação de navios nos berços & 0.014 & 11 \\
& 043 & Eficiência operacional do terminal & 0.038 & 8 \\
\hline
\end{tabular}

Fonte: Chung e Chiang, 2011

Por último, destaca-se que, apesar de usualmente constituir um importante gargalo às operações de logística e supply chain, as restrições de acesso aos terminais portuários obteve o menor peso entre os critérios observados, ou seja, apresenta pouca ou nenhuma influência no atraso das operações marítimas e, portanto, não serão incluídos no modelamento deste trabalho.

\subsection{PRODUTIVIDADE E MELHORIA DO PLANEJAMENTO DE ESCALAS}

Dada a importância da confiabilidade da programação das escalas para todas as entidades envolvidos no transporte marítimo, o tema é intensamente explorado durante os últimos anos. Christiansen e Fagerholt (2002) desenvolveram um modelo para navios 
graneleiros que visa distanciar o horário de chegada das embarcações nos terminais daqueles em que há cessão das operações no terminal, normalmente às noites e finais de semana, o que acarreta em longas esperas e potencial risco de atrasos. Para tanto, utilizaram uma função que adicionava um custo / penalidade para operações com atraso prolongado.

Wang, Li e Wu (2010) utilizam-se da técnica de ADE (Adaptive Differential Evolution) para minimizar a lacuna temporal existente entre o horário programado de saída do navio do porto versus o horário real de saída através da escolha mais adequada dos berços livres para os navios a serem operados em um determinado período.

Mais recentemente, Meijer, Mulder e van Oosterom (2016) desenvolveram dois modelos, um otimizante e outro heurístico com objetivo de estabelecer os melhores momentos para alocação de reservas de tempo, devido ao crescente acúmulo de atrasos antes destes pontos. Com isso, visa-se definir estratégias mais adequadas de recuperação do planejamento outrora definido, garantindo a pontualidade e credibilidade do serviço.

Embora as decisões que mais influenciam a elaboração de serviços de navegação confiáveis estejam sob controle do armador, Chung e Chiang (2011) mostram que a eficiência portuária também é um fator importante, sendo o principal dentre aqueles não gerenciados pelos transportadores. No Brasil, principalmente, este aspecto ganha relevância fundamental, devido à parca infraestrutura portuária (DE OLIVEIRA; DE SÁ PORTO, 2016; SILVEIRA; JÚNIOR, 2013) e à baixa produtividade dos terminais nacionais (LÓPEZ-BERMÚDEZ; FREIRESEOANE; GONZÁLEZ-LAXE, 2019)

Produtividade (ou eficiência) portuária é definida como a quantidade de movimentos realizada na operação de embarque e desembarque de um navio dividido pelo tempo necessário para a operação, medido em horas (TONGZON, 1995). O autor afirma que este parâmetro depende de uma série de fatores quantitativos e qualitativos, e propõe uma relação não-linear entre as diversas variáveis que impactam esta produtividade, como descrito abaixo:

$$
E=A * C O N M I X^{B 1} * B R L W T^{B 2} * G W L N^{B 3} * C H W H^{B 4} * T E U C H^{B 5} * C E^{B 6}
$$

Em que:

$\mathrm{E}=$ eficiência do terminal (TEUs por hora);

CONMIX $=$ mix de contêineres com base na porcentagem de unidades de 40 pés (\%);

BRLWT $=$ atraso pré-operacional (horas);

GWLN = atraso durante a operação (horas); 
$\mathrm{CHWH}=$ porcentagem de utilização global dos guindastes (adimensional);

TEUCH $=$ produtividade média dos equipamentos individualmente (movimentos por hora);

$\mathrm{CE}=$ tamanho do navio e quantidade movimentada.

É uma função, essencialmente, da capacidade operacional dos guindastes, da quantidade destes em operação, do sincronismo do processo entre o operador do equipamento e a fila de veículos que movimentam as unidades em solo e de planos de embarque e desembarque que facilitem a movimentação das unidades, além de possíveis atrasos inerentes à operação.

Visando minimizar os impactos negativos da baixa produtividade portuária, Notteboom (2006) mostra que acordos são frequentemente estabelecidos entre operadores portuários e seus clientes, determinando a mínima eficiência operacional que o terminal deve garantir e sujeito a penalizações financeiras em casos de não cumprimento. Durante as operações, todavia, a produtividade dos terminais se altera, positivamente ou negativamente, não raro ultrapassando o piso estabelecido em contrato. Dentre as diversas causas para estas variações, destacam-se possíveis quebras de guindastes e realocações de equipamentos em outras embarcações, ambas situações imprevisíveis, mas que afetam bruscamente a eficiência de determinada operação.

Do ponto de vista do armador, esta oscilação se apresenta com grande inconveniência, uma vez que a eficiência portuária é uma variável decisiva durante a elaboração da programação de escalas de seus serviços. Este parâmetro é básico para o cálculo do tempo de operação em um terminal, portanto fundamental para a correta elaboração do planejamento.

Reiteradamente, são utilizadas médias históricas acrescidas de alguma margem de segurança para estabelecimento do tempo da escala e, consequentemente, dos tempos da proforma como um todo. Esta prática, contudo, é temerária, uma vez que pode incluir tempo adicional não necessário a uma proforma estabelecida. Este tempo adicional gera uma ociosidade no sistema, ou seja, o navio é mantido mais tempo parado ao invés de se coletar novas cargas, diminuindo a geração de receitas para um mesmo custo de operação do sistema, afetando negativamente sua lucratividade.

\subsection{CABOTAGEM NO BRASIL}

Com pouco mais de 7.400 quilômetros de costa navegável, o Brasil apresenta um cenário bastante favorável ao transporte aquaviário, tanto de passageiros quanto de cargas, e, 
historicamente, este modal tem sido fator decisivo para o desenvolvimento nacional (PAIXAO CASACA et al., 2017; RONEN, 1983; SILVEIRA; JÚNIOR, 2013).

Mesmo assim, o sistema logístico brasileiro apresenta uma elevada dependência do modal rodoviário (DE OLIVEIRA; DE SÁ PORTO, 2016), correspondendo a pouco mais de $60 \%$ do volume da carga transportada no território nacional, conforme dados do CNT (2016). Tal condição é resultado do processo histórico do desenvolvimento da infraestrutura nacional, oriundo dos planos de investimento e das políticas adotadas ao longo do último século no Brasil.

Nos anos 1950, com a abertura do mercado nacional às empresas estrangeiras durante o governo de Juscelino Kubitschek, houve forte pressão política por parte das montadoras automobilísticas, recém implantadas no país, por maiores investimentos em infraestrutura rodoviária (PAIXAO CASACA et al., 2017). Neste mesmo período, verificou-se um processo de interiorização no país, inclusive com a transferência da capital (Rio de Janeiro, à época) para Brasília, no interior do território, que intensificou a necessidade urgente por investimentos em rodovias.

Segundo Cutrim et al. (2017), esta alta dependência criou diversos aspectos desfavoráveis à logística nacional, como aumento de preço dos transportes, derivado da escassa oferta de serviços e da baixa competitividade entre modais, e maiores riscos de avarias e roubos de cargas presentes neste modal, devido a maior facilidade de acesso a estas cargas e à condição socioeconômica e política do Brasil. Além disto, com a falta de alternativas para o escoamento e distribuição de cargas, oriundos do escasso investimento histórico em ferrovias e hidrovias, toda a logística do país fica sujeita às imposições das empresas de transporte rodoviário, como observado em meados de 2018, quando o aumento do preço do combustível pela Petrobrás, principal companhia petrolífera do Brasil, desencadeou uma greve de $\operatorname{transportadores}^{1}$ no país, com prejuízos alarmantes ao abastecimento nacional. Desde então, diversas empresas buscam soluções alternativas ao transporte de carga, como o transporte ferroviário e, mais destacadamente, o aquaviário (CAGLIARI, 2019).

O transporte ferroviário no Brasil é incipiente e ineficaz, com escassos investimentos e sempre visando ao escoamento de cargas do interior aos portos mais próximos, sem a constituição de uma malha nacional mais abrangente, conforme Oliveira e Sá Porto (2016). Além disto, o desenvolvimento foi realizado de forma heterogênea, com bitolas diferentes aplicadas ao longo da rede, impossibilitando uma conexão entre as malhas. Outro fator

\footnotetext{
${ }^{1}$ Em 21/05/2018, após seguidos aumentos no preço do óleo Diesel, os caminhoneiros organizaram um ato de paralisação do abastecimento nacional, instaurando o caos no país e evidenciando a fragilidade e a dependência da logística nacional ao setor rodoviário (GUEDES, 2018)
} 
importante, que dificulta a implementação deste meio em mais larga escala é geografia acidentada do Brasil, que exige a implementação de sistemas complexos e caros, como a cremalheira para subia de trechos íngremes, desestimulando o uso do modal.

Devido às características econômicas e geográficas brasileiras e à alta concentração de transporte de cargas em um único modal, rodoviário (CASACA et al., 2017), há grande demanda pelo transporte aquaviário de carga, estando a cabotagem brasileira dentre os maiores mercados de transporte marítimo do planeta. Este fato é ressaltado pelo consistente crescimento observado na última década, com taxa composta de, aproximadamente, 12\% ao ano (ANTAQ, 2018). Após a paralisação dos caminhoneiros em 2018, verificou-se um incremento médio de 17,5\%, segundo Cagliari (2019), com alguns corredores chegando a 20\% de aumento.

De acordo com o Art. $2^{\circ}$ da lei federal 10.893/04 (BRASIL, 2004), considera-se: "Navegação de cabotagem é aquela realizada entre portos brasileiros, utilizando exclusivamente a via marítima ou a via marítima e os interiores". Embora a constituição brasileira não considere, à risca, a extensão do transporte de Cabotagem ao atendimento de portos estrageiros, o conceito é estendido no âmbito do acordo Mercosul, através da constituição dos acordos bilaterais entre Brasil e Argentina (ANTAQ, 1990) e entre Brasil e Uruguai (ANTAQ, 1976). A adoção destes acordos restringe a navegação nos territórios destes países apenas a embarcações de companhias nacionais de um dos participantes do acordo, restrição similar àquela imposta à navegação costeira nacional, autorizada apenas à companhias brasileiras, com embarcações brasileiras ou estrangeiras, estas últimas sob regime específico de afretamento, de acordo com a lei federal 9.432/97 (BRASIL, 1997). Esta restrição significa, na prática, que os grandes armadores globais não são autorizados a realizarem qualquer movimentação interna no continente sul-americano, sendo obrigados a utilizar subsidiárias nacionais ou contratar empresas brasileiras.

Dentre as vantagens do uso do transporte de cabotagem, pode-se destacar o baixo índice de sinistralidade na costa nacional, menores níveis de emissões atmosféricas por tonelada transportada, maior capacidade de transporte, acarretando em maiores economias de escala e redução do custo logístico, maior vida útil da infraestrutura e a contribuição para o descongestionamento da malha rodoviária (DE OLIVEIRA; DE SÁ PORTO, 2016; PAIXAO CASACA et al., 2017; RONEN, 1983).

Todavia, o modal enfrenta desafios para seu crescimento devido à precária infraestrutura portuária, que culmina na baixa produtividade dos terminais, mesmo naqueles que apresentam grande volume de contêineres movimentados. Isto se reverte em grande transtorno aos operadores logísticos nacionais, que se observam forçados a aumentar o tempo de trânsito de 
seus navios, acarretando aumentos desnecessários de custos fixos, como medida para minimizar a baixa confiabilidade das operações costeiras.

Não obstante, a alta burocratização do transporte marítimo (SILVEIRA; JÚNIOR, 2013), bem como as restrições impostas pela legislação nacional ao transporte de cabotagem, como a exigência de frota nacional ou afretada com bandeira brasileira e tripulação brasileira (PAIXAO CASACA et al., 2017), afasta a atratividade por investimentos de empresas estrangeiras, que preferem aplicar seus recursos em outras atividades mais sólidas, prejudicando sobremaneira a evolução da infraestrutura nacional, fator preponderante para o contínuo desenvolvimento do setor e, por consequência, da economia nacional, como destaca Silveira e Júnior (2013).

Segundo Cutrim et al. (2017), a literatura acerca da cabotagem nacional contém, majoritariamente, estudos qualitativos, com enfoque principal nas barreiras e desafios ao desenvolvimento do modal no país e, em segundo plano, análises relativas à legislação e políticas que regem este transporte. Dentre os escassos trabalhos com característica quantitativa, Medeiros et al. (2015) utilizam a simulação computadorizada para avaliar a implementação de um serviço hub-and-spoke concentrado no estado do Amazonas, estado banhado pela maior bacia hidrográfica do planeta.

\subsection{SIMULAÇÃO E MODELOS ESTOCÁSTICOS}

Uma característica marcante do desenvolvimento científico nesta área é a presença consistente de modelamentos matemáticos. Meng et al. (2014) apresenta 70 estudos, endereçados a pelo menos um dos três níveis de tomada de decisão nesta área, que utilizam ferramentas de pesquisa operacional como metodologia, com destaque para programações linear, inteira e mista (BELL et al., 2011; BENDALL; STENT, 2001; BOFFEY et al., 1979; BROUER; PISINGER; SPOORENDONK, 2011; CHO; PERAKIS, 1996; FAGERHOLT, 1999, 2004; GELAREH; MENG, 2010; JARAMILLO; PERAKIS, 1991; LIU; YE; YUAN, 2011; MENG; WANG, 2011, 2010; PERAKIS; JARAMILLO, 1991; POWELL; PERAKIS, 1997; WANG; MENG, 2012a, 2012b; WANG; WANG; MENG, 2011; YAO; NG; LEE, 2012).

Ronen (1983) destaca, contudo, que a complexidade e variabilidade são características determinantes nos problemas que envolvem Liner Shipping, dizimando a capacidade de aplicação de modelos determinísticos, ao passo que heurísticas e simulações se mostram mais adequados. Embora diversos trabalhos heurísitcos tenham sido realizados (BOFFEY et al., 1979; CHUANG et al., 2010; FAGERHOLT; JOHNSEN; LINDSTAD, 2009; GELAREH; 
NICKEL; PISINGER， 2010; GELAREH; PISINGER， 2011; KARLAFTIS; KEPAPTSOGLOU; SAMBRACOS, 2009; MENG; WANG; LIU, 2012; MENG; WANG; WANG, 2012; RANA; VICKSON, 1991; SAMBRACOS et al., 2004; SHINTANI et al., 2007; SONG; DONG, 2012; WANG; MENG, 2011; YAN; CHEN; LIN, 2009), poucos modelos de simulação foram desenvolvidos (LANG; VEENSTRA, 2010; MEDEIROS et al., 2015).

Consoante Saliby (1999), sistemas logísticos são definidos como sistemas dinâmicos complexos, em que as diversas variáveis que atuam no sistema interagem entre si, influenciamse mutuamente e são, majoritariamente aleatórias. Em cenários como este, a aplicação de simulação a eventos discretos constitui uma das principais ferramentas de auxílio à tomada de decisão.

Por definição, a simulação é uma imitação de um sistema real, realizado manualmente ou computacionalmente, com o intuito de se observar e prever o comportamento deste sistema (BANKS et al., 2009). Para tanto, são desenvolvidos modelos, que visam refletir, com a maior fidelidade possível, a realidade a ser estudada (SANTOS; LEAL JR; FILHO, 2004). Uma vez que o modelo esteja construído e validado, são conduzidos experimentos computacionais, sempre com a finalidade de se entender como o sistema funcionará a partir de algumas premissas estabelecidas (SALIBY, 1999). A definição destas premissas pode ser baseada no modus operandi do sistema estudado, ou então com algumas alterações, visando testar cenários e avaliá-los.

Algumas vantagens da simulação, conforme Banks et al. (2009), são a capacidade de testar cenários em sistemas existentes ou em desenvolvimento, sem os custos que a sua implementação definitiva envolvem, avaliar possíveis gargalos, identificar soluções previamente e realizar análises com universos temporais longínquos em estudos de viabilidade operacional e financeira. Em contrapartida, aponta-se como desvantagens desta técnica a complexidade inerente à criação do modelo - fator decisivo para a assertividade dos resultados - e a dificuldade na interpretação de resultados, usualmente na forma de variáveis aleatórias, que demandam bastante destreza do analista ao apurar sua plausibilidade.

Saliby (1999) define três etapas para a elaboração de um projeto de simulação: construção do modelo, modelagem computacional e experimentação. O primeiro é também o mais desafiador, pois consiste em compreender vastamente o sistema estudado, avaliando suas variáveis, dependências e condições de contorno adequadamente, de forma a obter um modelo fiel e aplicável à realidade. Nesta etapa, os objetivos da simulação também devem ser determinados. 
A segunda parte se refere à tradução do modelo previamente determinado para a linguagem computacional em softwares especializados, na forma de um conjunto de ações e lógicas que serão efetuadas durante o processo de experimentação. Esta fase pode ser subdividida em outras três seções: coleta de dados (alimentação do software com os dados necessários para a correta condução do processo), programação (estabelecimento das regras e sequenciamento a serem conduzidos pelo software durante o processamento do modelo) e validação (verificação se o modelo desenvolvido é aderente ao sistema real).

Por fim, na etapa de experimentação avalia-se o comportamento do sistema nas mais diversas condições possíveis, estabelecidas pelo analista. São testadas diversas alternativas de funcionamento do sistema, conduzidas análises de cenários e testes de sensibilidade, entre outras (SALIBY, 1999). Os resultados do processo de simulação nunca devem ser encarados como o fim do processo decisório, mas sim servir de ferramenta de auxílio para um arbítrio mais assertivo. 


\section{MODELAGEM}

"Planejamento de longo prazo não lida com decisões futuras, mas com um futuro de decisões presentes."

(Peter Drucker)

Nas seções vindouras, serão expostos o serviço real de uma empresa de Cabotagem brasileira, no qual este estudo foi baseado, as técnicas de modelagem aplicadas, as condições de contorno estabelecidas e simplificações adotadas.

\subsection{O SERVIÇO}

O objeto de estudo deste trabalho é o serviço de Cabotagem de uma empresa com destacada atuação no mercado brasileiro, desenhado de modo a suprir não somente a demanda nacional pelo transporte de cargas, assim como ao atendimento aos portos da Argentina, como parte da Grande Cabotagem (SEABRA; FLORES; BALISTIERI, 2017).

A infraestrutura portuária deficitária não se restringe apenas ao Brasil, mas também é visualizada em outras localidades da América do Sul, como exemplo, todos os portos da região da Patagônia, local importante para a economia argentina devido à exportação de frutas e peixes para o resto do mundo. Este déficit de infraestrutura dificulta o emprego de embarcações maiores, tendência corrente em todo o planeta como uma maneira de aumentar a economia de escala e reduzir os custos operacionais. Tal limitação estrutural, adicionada à restrição imposta pelos acordos do Mercosul, impõe às grandes empresas a criação de serviços feeder (MENG et al., 2014). Neste conceito, a malha é composta por um ou alguns poucos serviços principais, operados por grandes e eficientes navios que escalam portos-chave de uma determinada região, complementados por uma série de outros serviços menores, por sua vez operacionalizados por embarcações pequenas e responsáveis pela distribuição das cargas às demais localidades da região.

Desta forma, é estabelecido um formato de malha único, não necessário nem visualizado em outras regiões, em que cada anel da malha é concomitantemente serviço principal, atendendo à demanda nacional, e serviço feeder, prestando serviço às grandes malhas internacionais de importação e exportação. Esta característica única é altamente relevante e 
adiciona complexidade à estruturação das malhas de cabotagem, já que praticamente dobra a demanda de transporte na região sul-americana.

Levando em consideração os fatores apresentados e visando ao atendimento pleno das demandas nacional e internacionais, foi conceituado um serviço composto por 5 anéis, dos quais 4 são destinados exclusivamente à Cabotagem brasileira e o último atendendo à Grande Cabotagem. Com esta configuração, a companhia atende regularmente a 16 portos, dos quais 13 são brasileiros, além de escalar dois terminais portuários diferentes no porto de Santos, medida tomada para aumentar a cobertura de cargas de parceiros estrangeiros.

O serviço é, ainda, atendido por 12 navios, sendo 6 próprios, 3 afretados a casco nu (modalidade de afretamento em que a empresa recebe apenas o navio "nu", sendo de sua responsabilidade a alocação da tripulação, realização de manutenção, contratação de seguro e compra de suprimentos necessários para a operação da embarcação), 2 afretados por tempo determinado (nesta modalidade de afretamento, a empresa recebe a embarcação "completa", ou seja, pronta para entrar em operação e não precisa arcar adicionalmente com demais custos operacionais relacionados ao navio) e o último em parceria com uma empresa terceira, operadora da embarcação. A decisão pelo tipo de afretamento é resultado de uma combinação de fatores financeiros e legais, uma vez que a ANTAQ, órgão que regulamenta o transporte aquaviário no Brasil, determina que a operação deve ser realizada por embarcações próprias ou afretadas com suspensão de bandeira brasileira, salvo determinados regimes excepcionais por tempo limitado e sujeitos a autorização prévia da entidade. Como premissa deste modelo, os navios, suas capacidades e respectivos tipos de afretamento já se encontram pré-determinados.

\subsection{A PROFORMA}

A primeira e mais importante informação contida na proforma é quais portos o serviço escala e qual a ordem de atendimento aos mesmos. Este documento determina também a frequência em que os portos serão escalados. Usualmente, as proformas são definidas com escalas semanais nos portos (MENG et al., 2014), padrão adotado pela indústria por estabelecer um trade-off adequado entre a demanda por frequência dos clientes e a necessidade de acúmulo de carga para os armadores. Ainda conforme Meng et al. (2014), escalas semanais estabelecem um padrão, no qual navios do mesmo tamanho escalarão determinado terminal sempre no mesmo dia da semana, facilitando o planejamento portuário. Assim, os terminais alocam janelas de atracação aos armadores, tempo nos quais a chegada de um navio que pertence ao serviço 
em questão acarreta em imediata atracação, uma vez que o espaço para a embarcação está reservado e garantido.

Para cada escala de uma proforma, são determinadas as durações das manobras de atracação e desatracação, que consistem no encaminhamento do navio desde a área costeira, conhecida como barra portuária, até o completo estacionamento junto ao cais do terminal, e vice e versa. Além disto, são estimadas a média de movimentações esperada para o terminal em questão, baseada na expectativa comercial do negócio, assim como uma produtividade portuária adequada, conforme convencionado entre terminal e armador por meio de contrato de performance.

Numa terceira etapa, são determinadas as velocidades de navegação, variável de extrema importância devido a sua grande influência no consumo de combustível, custo que pode chegar a $75 \%$ do custo fixo total de um sistema de Liner Shipping (MENG et al., 2014). Wang e Meng (2012), mostram que a relação entre velocidade e consumo de uma embarcação se aproxima de uma equação polinomial com expoente variando entre 2,7 e 3,3, a depender de diversos fatores como tamanho da embarcação, tecnologia dos propulsores e utilização projetada. Visando maior economia e menor impacto ambiental, as proformas são calculadas buscando ao máximo a operação na faixa de maior eficiência do propulsor, o que se traduz no estabelecimento de velocidades pré-determinadas para as diversas rotas a serem percorridas.

Uma vez determinados a ordem dos portos escalados, os tempos estimados de operação e os tempos de navegação entre escalas, a definição final é a quantidade de navios necessários para atendimento e suas capacidades. Durante a operação regular, diversas são as variáveis que podem causar potenciais atrasos. Chung e Chiang (2011) apresentam 12 aspectos com potencial de diminuir a confiabilidade da programação destes serviços, sendo que, alguns destes fatores, não são gerenciados pelo armador. Notteboom (2006) lembra que congestionamentos e aspectos meteorológicos também são fatores imprevisíveis, mas que podem causar sérios problemas à programação das escalas. Em vista disto, as proformas jamais são elaboradas de maneira justa, mas sim com alguma folga (buffer), uma prática que, embora alivie a pressão temporal sobre os serviços, acrescenta um custo extra ao sistema, já que este tempo parado não é produtivo (MULDER; DEKKER, 2019).

Somando-se os tempos necessários para as escalas nos portos e os tempos navegados, adicionam-se horas de buffer suficientes para estabelecer uma proforma confiável e de forma a completar um número múltiplo de 7 , pois esta matemática garante a frequência semanal, no mesmo horário, em cada porto do serviço. Por sua vez, o outro divisor da quantidade total de 
horas estabelecida representa a quantidade de embarcações necessárias para cumprir esta frequência.

As capacidades das embarcações dependem não somente da demanda de carga prevista para o sistema, como também da disponibilidade da mesma pela empresa ou pelo mercado de afretamento, assim como de seu preço no mercado. Por se tratar de um ativo caro e com vida útil muito grande, a correta alocação das embarcações também é um fator muito importante na composição de um serviço, motivo pelo qual estudos que tratam da composição de frota tem ganhado bastante relevância na última década (MENG et al., 2014).

Especificamente na cabotagem brasileira, o cálculo da capacidade mínima necessária não é linear como em serviços de travessia oceânica de Longo Curso. Neste último, a determinação da capacidade mínima necessária é resultante da soma das demandas de cada porto da região exportadora, em vermelho no exemplo da figura 2. Como não é realizado nenhum embarque de Cabotagem nestes sistemas, não autorizados pela legislação nacional por se tratarem de armadores e embarcações estrangeiras, toda a carga embarcada nos portos vermelhos são obrigatoriamente destinados à exportação e desembarcados na região importadora, em amarelo, resultando em o trecho de travessia oceânica sendo aquele de maior concentração de cargas e, portanto, o determinante para a capacidade mínima das embarcações empregadas no sistema. 
Figura 2 - Utilização em sistemas de Longo Curso

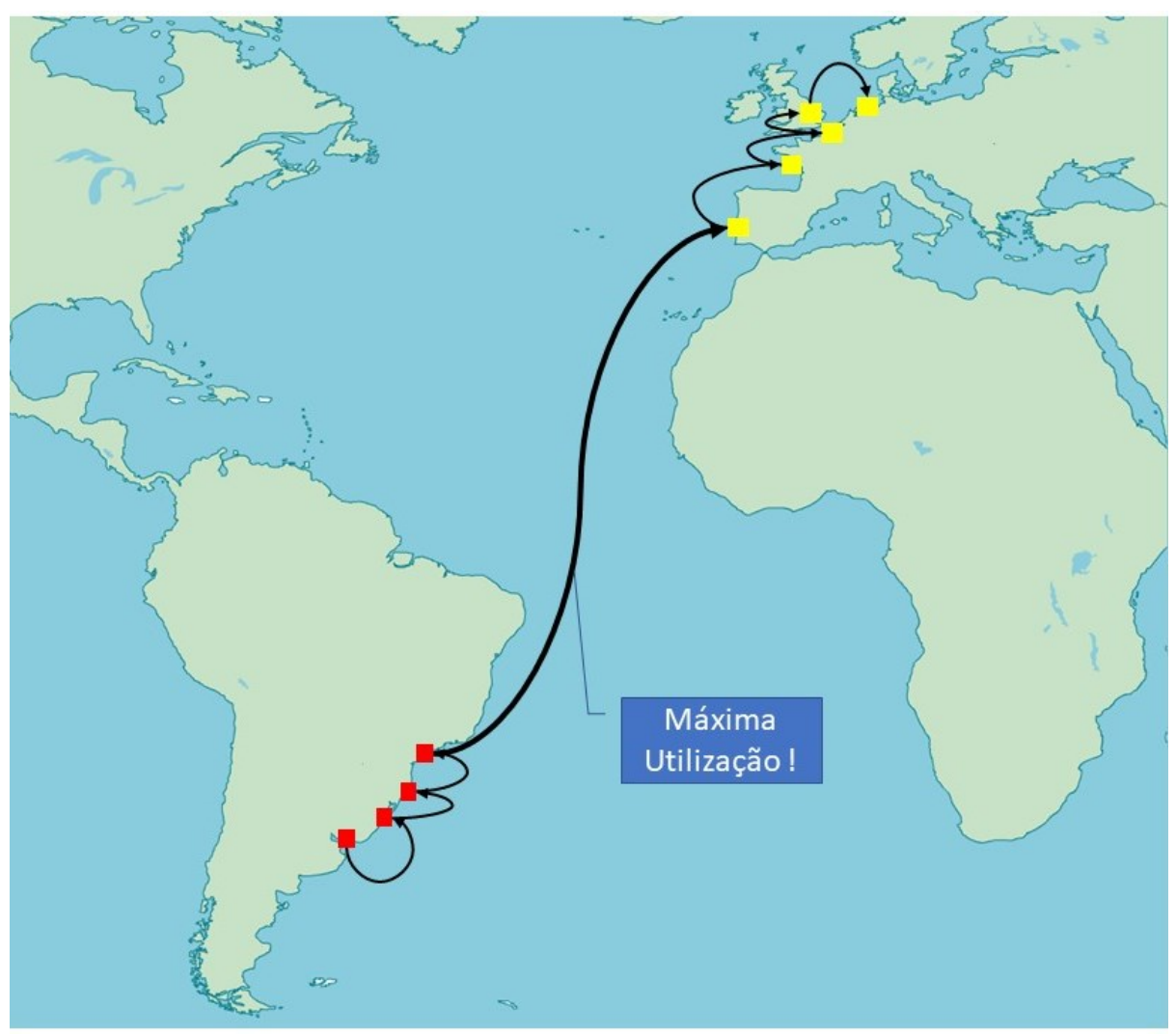

Fonte: Autor

$\mathrm{Na}$ Cabotagem brasileira, por sua vez, ocorre uma dupla utilização do espaço, devido às grandes proporções territoriais deste país, permitindo que um contêiner desembarque num porto e outro ocupe este mesmo espaço, ainda na mesma viagem. Como exemplificado na figura 3 , os portos da região Sul, em vermelho, embarcam carga tanto para a região Nordeste, em amarelo, quanto para a região Norte, em laranja. A descarga dos contêineres provenientes dos portos sulistas e sudestinos nos portos nordestinos libera um espaço adicional para a demanda desta região com destino ao norte do país, resultando nesta dupla utilização. Como consequência, a mera soma algébrica das demandas de cada localidade, como ocorre no Longo Curso, sobrestimaria a capacidade mínima das embarcações para a Cabotagem, acrescendo um custo desnecessário ao sistema, que permaneceria subutilizado por toda sua operação. Neste caso, avalia-se a utilização do sistema a cada partida e, uma vez identificado o gargalo, determina-se a capacidade mínima necessária das embarcações. 
Figura 3 - Utilização em sistemas de Cabotagem

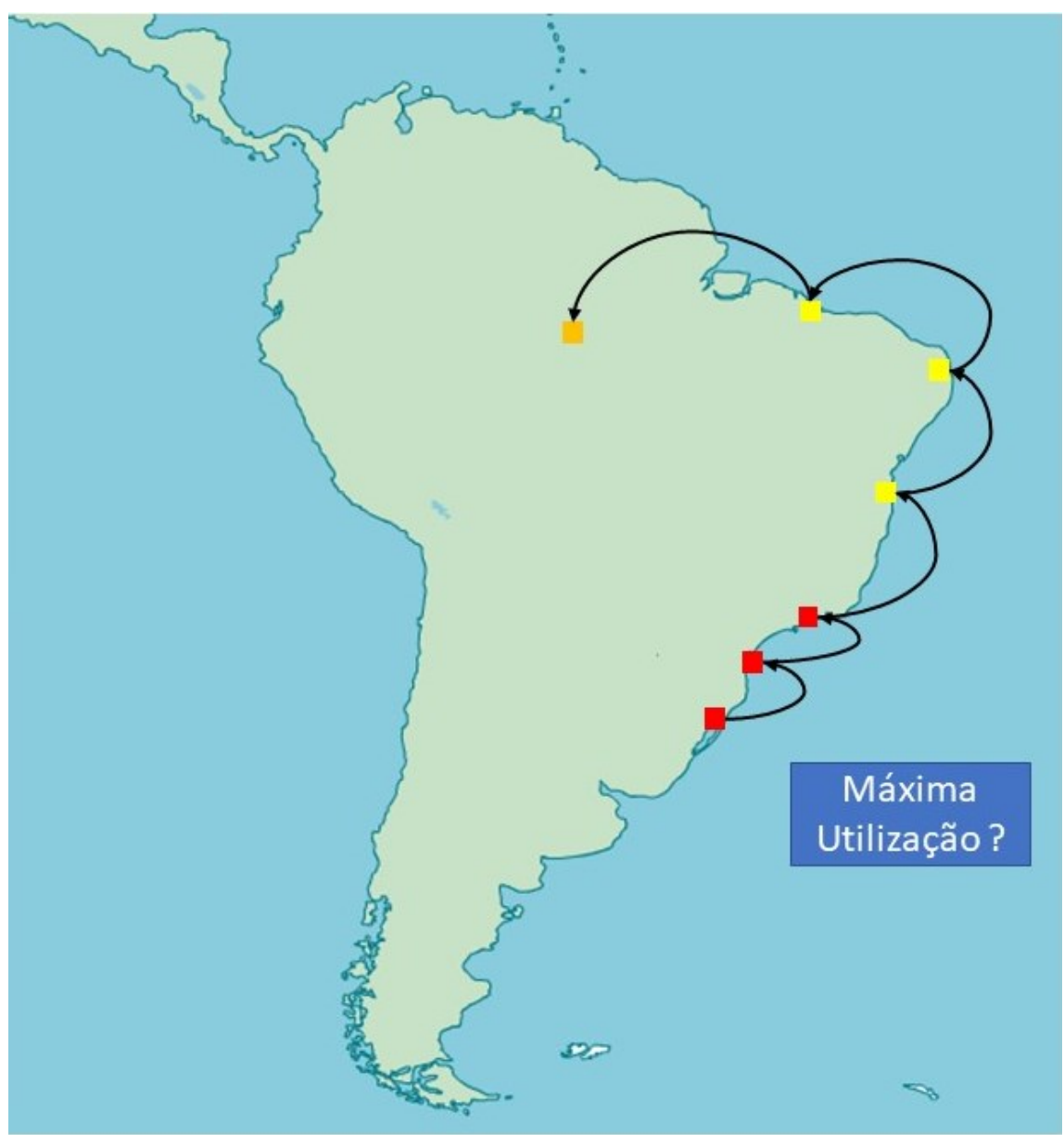

Fonte: Autor

Quando concluída, a proforma final é apresentada em formato de tabela, como observado na tabela 3 .

Tabela 3 - Exemplo de profoma final

\begin{tabular}{|c|c|c|c|c|c|c|c|c|c|c|c|c|c|c|c|}
\hline \multicolumn{6}{|c|}{ PROFORMA } & \multicolumn{10}{|c|}{2 navios, 14 dias, 13.7 nós } \\
\hline ANEL: & 3 & & & & & & & & & & & & & & \\
\hline $\begin{array}{c}\text { Início } \\
\text { Atracação }\end{array}$ & $\begin{array}{l}\text { Tempo } \\
\text { Atrac. }\end{array}$ & $\begin{array}{l}\text { Chegada } \\
\text { Terminal }\end{array}$ & Porto & $\begin{array}{c}\text { Tempo } \\
\text { Total } \\
\end{array}$ & $\begin{array}{l}\text { Espera } \\
\text { Pré-Op }\end{array}$ & $\begin{array}{l}\text { Prod. } \\
\text { Média }\end{array}$ & $\begin{array}{c}\text { No. } \\
\text { Guindastes }\end{array}$ & $\begin{array}{l}\text { Volume } \\
\text { Operado }\end{array}$ & $\begin{array}{l}\text { Espera } \\
\text { Pós-Op }\end{array}$ & $\begin{array}{l}\text { Saída } \\
\text { Terminal }\end{array}$ & $\begin{array}{c}\text { Tempo } \\
\text { Desatrac. }\end{array}$ & $\begin{array}{c}\text { Tempo } \\
\text { Navegado }\end{array}$ & $\begin{array}{c}\text { Milhas } \\
\text { Navegadas }\end{array}$ & $\begin{array}{l}\text { Velocidade } \\
\text { Navegação }\end{array}$ & Buffer \\
\hline sáb 6:00 & 0 & sáb 6:00 & Recalada & 1 & 1 & 1 & 0 & 0 & 0 & sáb 7:00 & 0 & & & & \\
\hline dom 3:00 & 2 & & Buenos Aires & 18 & 1 & 15 & 2 & 470 & 1 & dom 23:00 & 2 & 12.0 & 138 & 11.5 & 8.0 \\
\hline & & & & & & & & & & & & 9.1 & 105 & 11.5 & 8.9 \\
\hline seg 19:00 & 2 & seg 21:00 & Zarate & 42 & 1 & 13 & 2 & 1000 & 3 & qua 15:00 & 2 & & & & \\
\hline qui 3:00 & 1 & qui $4: 00$ & Rosario & 19 & 1 & 12 & 2 & 400 & 1 & qui 23:00 & 1 & 10.0 & 138 & 13.1 & 0.0 \\
\hline & & & & & & & & & & & & 23.0 & 305 & 13.3 & 0.0 \\
\hline $\operatorname{sex} 23: 00$ & 0 & sex 23:00 & Recalada & 0 & 1 & 1 & 0 & 0 & 0 & sex 23:00 & 0 & 55.0 & 717 & 13.0 & 0.0 \\
\hline seg 6:00 & 1 & $\operatorname{seg} 7: 00$ & Itapoa & 11 & 1 & 17.5 & 2 & 350 & 0 & seg $18: 00$ & 1 & & & & \\
\hline ter 7:00 & 1 & ter $8: 00$ & Santos BTP & 8 & 1 & 15 & 2 & 200 & 0 & ter $16: 00$ & 1 & 12.0 & 165 & 13.7 & 0.0 \\
\hline & & & & & & & & & & & & 0.3 & 4 & 11.5 & 1.7 \\
\hline ter 19:00 & 1 & ter 20:00 & Santos SBSA & 24 & 1 & 33 & 2 & 1500 & 0 & qua 20:00 & 1 & 57.0 & 876 & 15.4 & 0.0 \\
\hline sáb 6:00 & 0 & sáb 6:00 & Recalada & & & & & & & & & & & & \\
\hline
\end{tabular}

Fonte: Autor 
O serviço de Cabotagem analisado neste trabalho é composto por 5 anéis, dos quais 4 são operados pelo armador objeto deste estudo, que é também o proprietário da maior parte da frota aqui visualizada, e o último anel operado por uma empresa terceira, da qual é realizada a compra do espaço necessário para atender a demanda deste armador e seus respectivos clientes. Assim, embora existam 5 proformas estruturadas para este serviço, em apenas uma não se tem acesso aos detalhes da operação. Neste caso, isto não é um problema, pois a informação da programação das escalas, disponível via internet, é suficiente para garantir o modelamento do serviço, já que o espaço é comprado por um valor pré-determinado em contrato e o controle de alocação e escolha de carga fica sob responsabilidade da empresa terceira, dona da embarcação.

Como mencionado anteriormente, este estudo não tem a intenção de determinar qual a melhor proforma para uma determinada frota e demanda de carga, mas sim visualizar o funcionamento desta proforma ao longo do tempo, ou seja, validar se esta programação atrelada às variabilidades inerentes às operações, como variações de demanda, de produtividade dos terminais e intempéries climáticas ainda resultaria em um sistema com confiabilidade satisfatória, ou se ajustes na proforma se fazem necessários para aumentar sua confiabilidade. Assim, o processo de elaboração das proformas não seguiu modelos otimizantes ou heurísticas encontradas na literatura, mas sim determinadas de maneira empírica, como usualmente realizado pela empresa analisada.

As proformas de cada anel podem ser visualizadas detalhadamente no Apêndice A, ao passo que a tabela 4 apresenta, de maneira resumida, as características principais de cada anel do serviço. Nela são apresentadas os dados operacionais, da própria empresa ou da terceira, informando o tempo de trânsito para finalização de uma viagem de ida e volta, expresso em dias, a quantidade de navios em operação e suas capacidades, expressas em TEU (twenty-foot equivalent unit), medida que remete ao equivalente a um contêiner de 20 pés, os portos atendidos por cada anel e as velocidades média e máxima de navegação do sistema, expressa em nós - cada nó representa uma milha náutica $(\mathrm{mn})$ navegada em uma hora. A frequência de todos os anéis é semanal. 
Tabela 4 - Resumo do Serviço de Cabotagem com 5 anéis

\begin{tabular}{|c|c|c|c|c|c|}
\hline & Anel 1 & Anel 2 & Anel 3 & Anel 4 & Anel 5 \\
\hline Operação & Própria & Própria & Própria & Terceira & Própria \\
\hline Tempo de trânsito & 35 & 21 & 14 & 7 & 7 \\
\hline Navios & 5 & 3 & 2 & 1 & 1 \\
\hline Capacidade por navio & 2800 & 3800 & 2500 & 1500 & 1000 \\
\hline Portos Atendidos & $\begin{array}{l}\text { Itapoa } \\
\text { Santos } \\
\text { Sepetiba } \\
\text { Salvador } \\
\text { Suape } \\
\text { Pecém } \\
\text { Manaus }\end{array}$ & $\begin{array}{l}\text { Rio Grande } \\
\text { Imbituba } \\
\text { Santos } \\
\text { Salvador } \\
\text { Suape } \\
\text { Pecém }\end{array}$ & $\begin{array}{l}\text { Buenos Aires } \\
\text { Zarate } \\
\text { Rosario } \\
\text { Itapoa } \\
\text { Santos }\end{array}$ & $\begin{array}{l}\text { Santos } \\
\text { Rio de Janeiro } \\
\text { Vitória }\end{array}$ & $\begin{array}{l}\text { Pecém } \\
\text { Vila do Conde } \\
\text { São Luiz }\end{array}$ \\
\hline Velocidade Média & 13.7 & 13.3 & 13.7 & $\mathrm{~N} / \mathrm{D}$ & 13.5 \\
\hline Velocidade Máxima & 17.3 & 15.6 & 15.4 & $\mathrm{~N} / \mathrm{D}$ & 13.5 \\
\hline
\end{tabular}

Fonte: Autor

\subsection{O MODELO}

Saliby (1999) estabelece que a construção do modelo é a primeira e mais desafiadora das etapas para a realização de uma simulação a eventos discretos com sucesso. A construção do modelo visa replicar o fenômeno real da maneira mais fidedigna possível. O sucesso nesta representação é fator determinante para obter êxito na aplicação desta metodologia.

Com as proformas devidamente estabelecidas, segue-se com o modelamento inicial dos portos atendidos e seu sequenciamento, com a respectiva plotagem dos anéis no mapa, etapa importante tanto para que o leitor obtenha melhor visualização da disposição geográfica, como também para facilitar o entendimento do escopo de cada anel. Os anéis 1 e 2, apresentados na figura 4, são os maiores e mais importantes para a cabotagem brasileira, pois são as rotações que abrangem a maior parte dos portos escalados pelo armador na costa nacional, assim como aqueles operados pelos navios de maior capacidade. São também sistemas fundamentais para o escoamento das cargas destinadas ao exterior ou provenientes dele, atuando como feeder para os serviços destinados ao longo curso, os quais são operados com navios de capacidade significativamente mais elevada e com escalas apenas em portos maiores e com alta eficiência, concomitantemente ao atendimento do mercado nacional. 
Figura 4 - Disposição dos anéis 1 (esquerda) e 2 (direita)
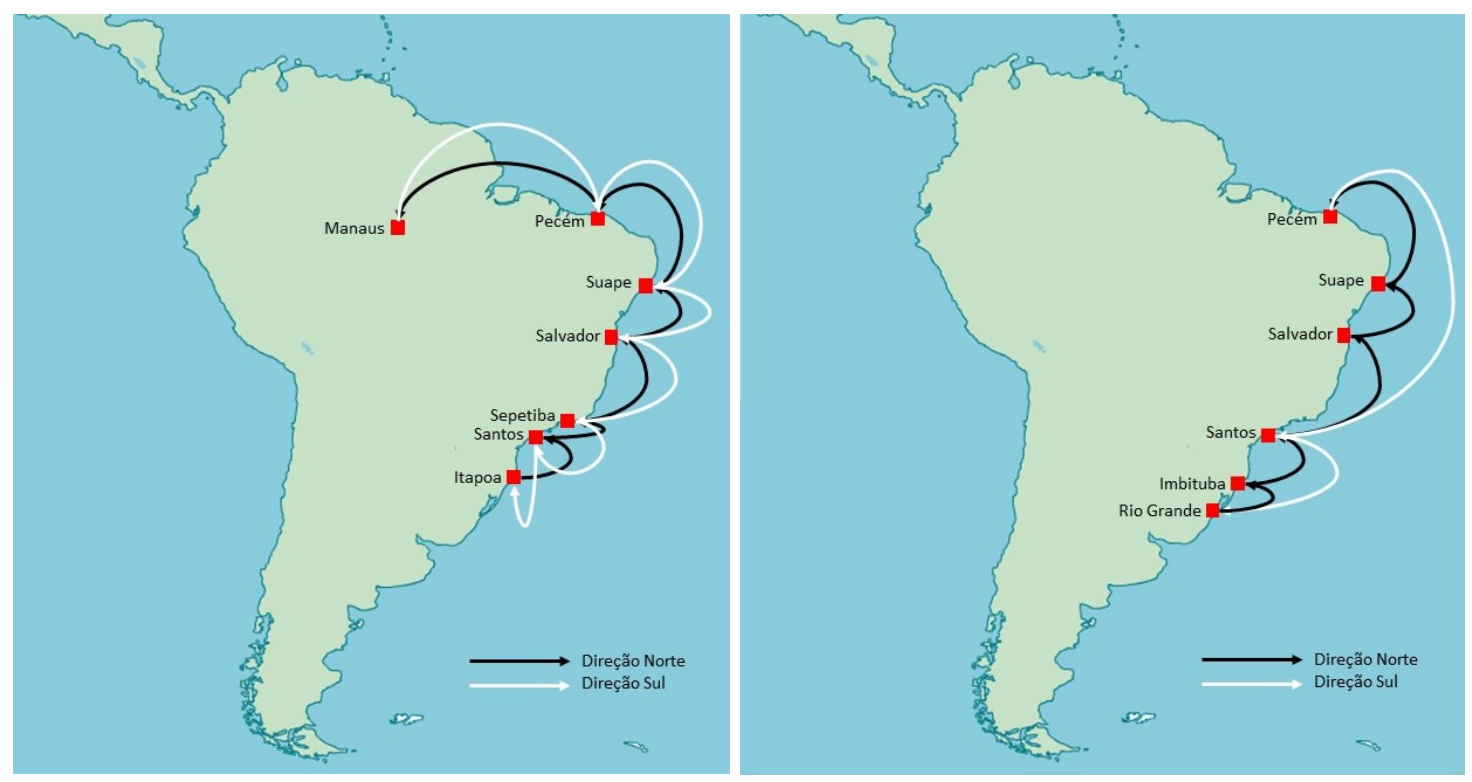

Fonte: Autor

Visualiza-se, também, que o terceiro anel serve exclusivamente para atendimento das cargas argentinas, seja referente ao mercado do Mercosul ou para exportação e importação daquele país, sendo escalados apenas dois portos brasileiros, que desempenham o papel de porto de conexão para outros portos no Brasil ou ao exterior. Vale destacar que a legislação brasileira não impede que nenhum serviço dedicado ao transporte internacional transporte também cargas domésticas do Brasil. No entanto, as exigências da ANTAQ para a Cabotagem restringem financeiramente a viabilidade de serviços híbridos, pois o custo envolvido na manutenção de uma frota brasileira operada por tripulação brasileira é significativamente maior do que a operação de frota e tripulação estrangeiros. Seguindo este raciocínio, o anel 3 também foi projetado com frota estrangeira, tornando-o apto apenas ao atendimento do Mercosul.

Um segundo fator importante, que contribui para que o serviço seja curto e atendido por navios de tamanho reduzido são as diversas restrições impostas pelas condições operacionais e geográficas dos portos atendidos. O atendimento aos portos de Zarate e Rosario exigem um trecho de navegação fluvial pelo Rio Paraná, restringindo o calado máximo de operação. Além disto, o calado aéreo também não pode ser excessivamente elevado, pois existe uma ponte sobre o mesmo rio na cidade de Zarate, mostrada na figura 5. 
Figura 5 - Ponte de Zarate

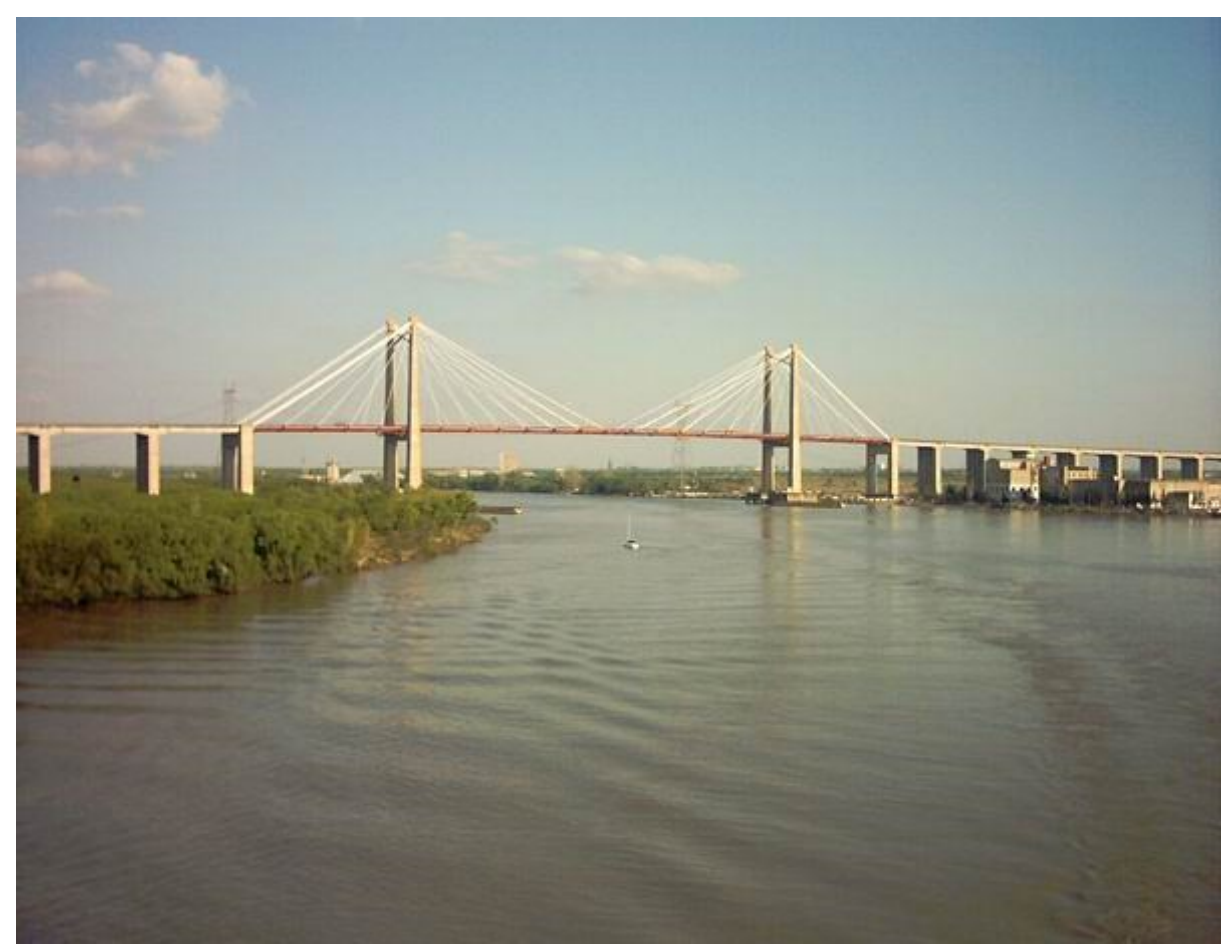

Fonte: Claudio Elias, 2007

Por fim, os anéis 4 e 5 são sistemas dedicados ao atendimento dos mercados locais de Vitória e Vila do Conde, portos com peculiaridades operacionais que corroboram a decisão pelo isolamento deles. No caso do ancoradouro mais setentrional, a produtividade portuária é muito deficitária, incorrendo em riscos significativos à confiabilidade do bastante populado anel 1, ao passo que sua inserção no anel 2 exige o mesmo deslocamento realizado pelo anel 5, porém com navios maiores e mais onerosos, inviabilizando financeiramente tal decisão. O porto capixaba, por sua vez, encontra-se em área de preservação ambiental e tem canal de acesso com calado demasiado restrito, limitando o tamanho dos navios que o acessam, no ponto de vista da segurança da operação, inviabilizando, portanto, sua inserção em qualquer um dos dois primeiros anéis.

A figura 6 apresenta o terminal Convicon em Vila do Conde, com destaque para presença de guindastes do tipo MHC, sigla para Mobile Harbour Crane, ou Grua Móvel de Porto, em tradução livre, que, embora leve e versátil para a movimentação de cargas em portos, tem velocidade de operação muito inferior ao sistema STS, sigla para Ship-to-Shore Crane. Os sistemas MHC e STS são apresentados, respectivamente, nas figuras 7 e 8. 
Figura 6 - Terminal Convicon em Vila do Conde

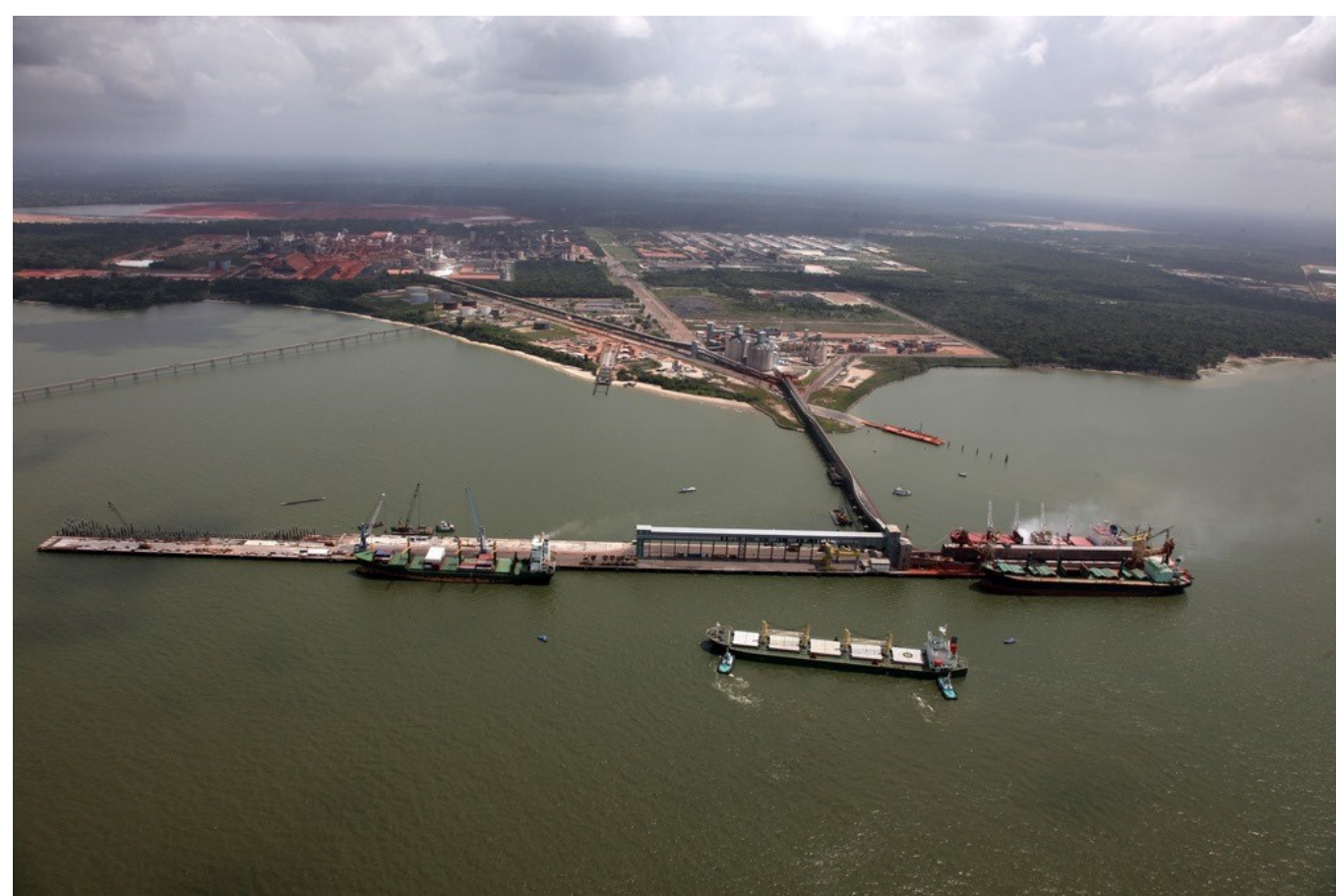

Fonte: Alyrio Sabba, 2017

Figura 7 - Sistema de guindaste MHC

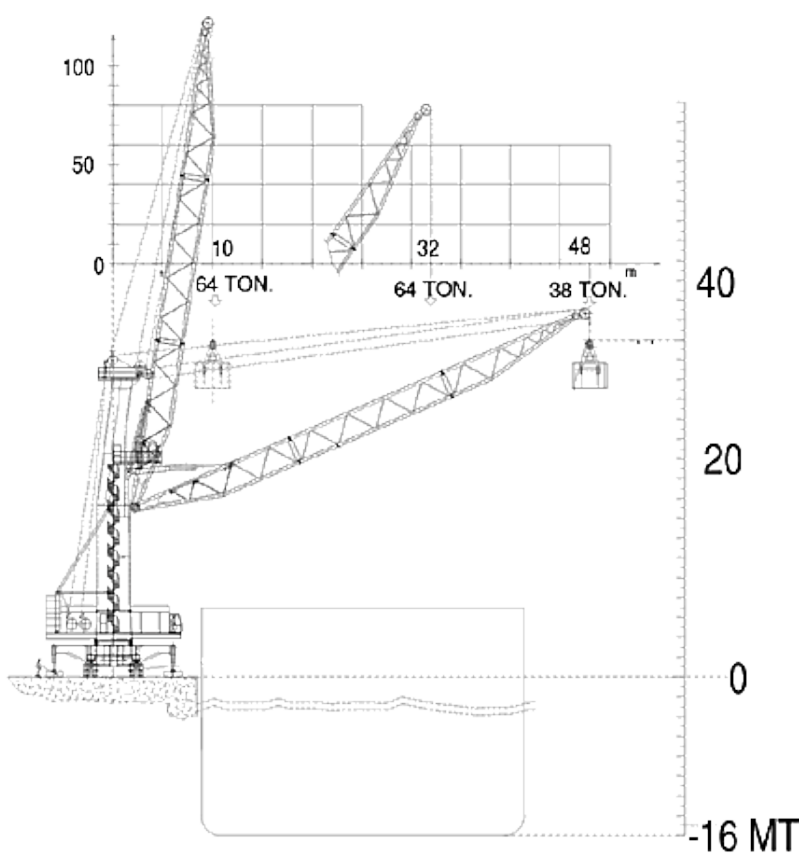

Fonte: OGMO Itajaí, 2020 
Figura 8 - Sistema de guindaste STS

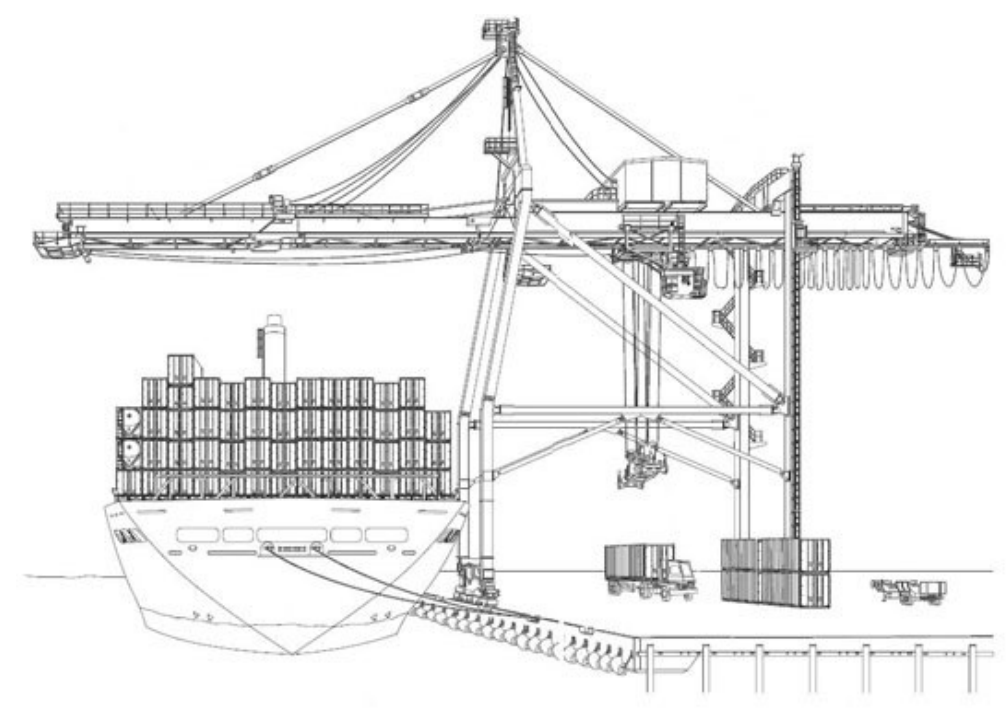

Fonte: OGMO Itajaí, 2020

O porto de Vitória e seu principal terminal de contêineres, Terminal de Vila Velha (TVV), podem ser visualizados na figura 9. O morro do Penedo, à esquerda, defronte à curva do Saldanha (direita) causam uma constrição natural no canal de acesso, limitando o espaço de manobra para embarcações de maior porte.

Figura 9 - Canal de acesso ao porto de Vitória

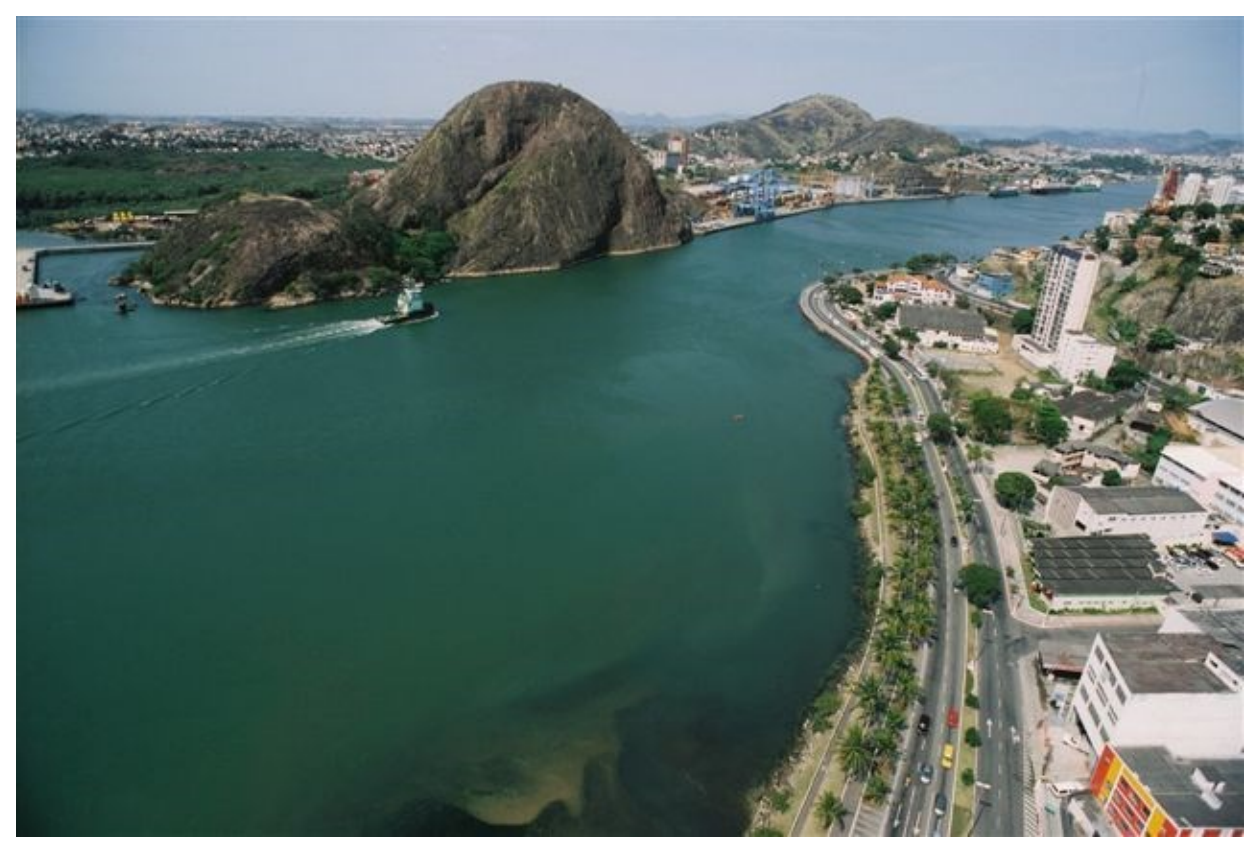

Fonte: Viniciusvix, 2010 
As figuras 10 e 11 apresentam a configuração, respectivamente, do anel 3, dedicado ao Mercosul, e dos anéis 4 e 5, respectivamente feeders dos postos de Vitória e Vila do Conde.

Figura 10 - Disposição do anel 3

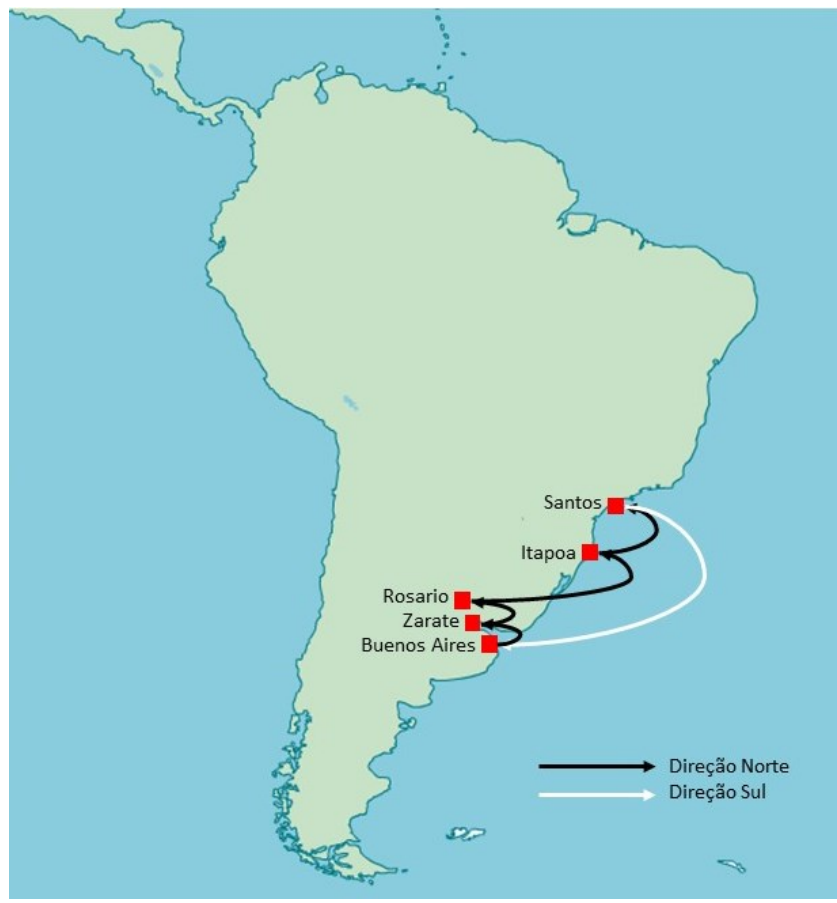

Fonte: Autor

Figura 11 - Disposição dos anéis 4 (esquerda) e 5 (direita)
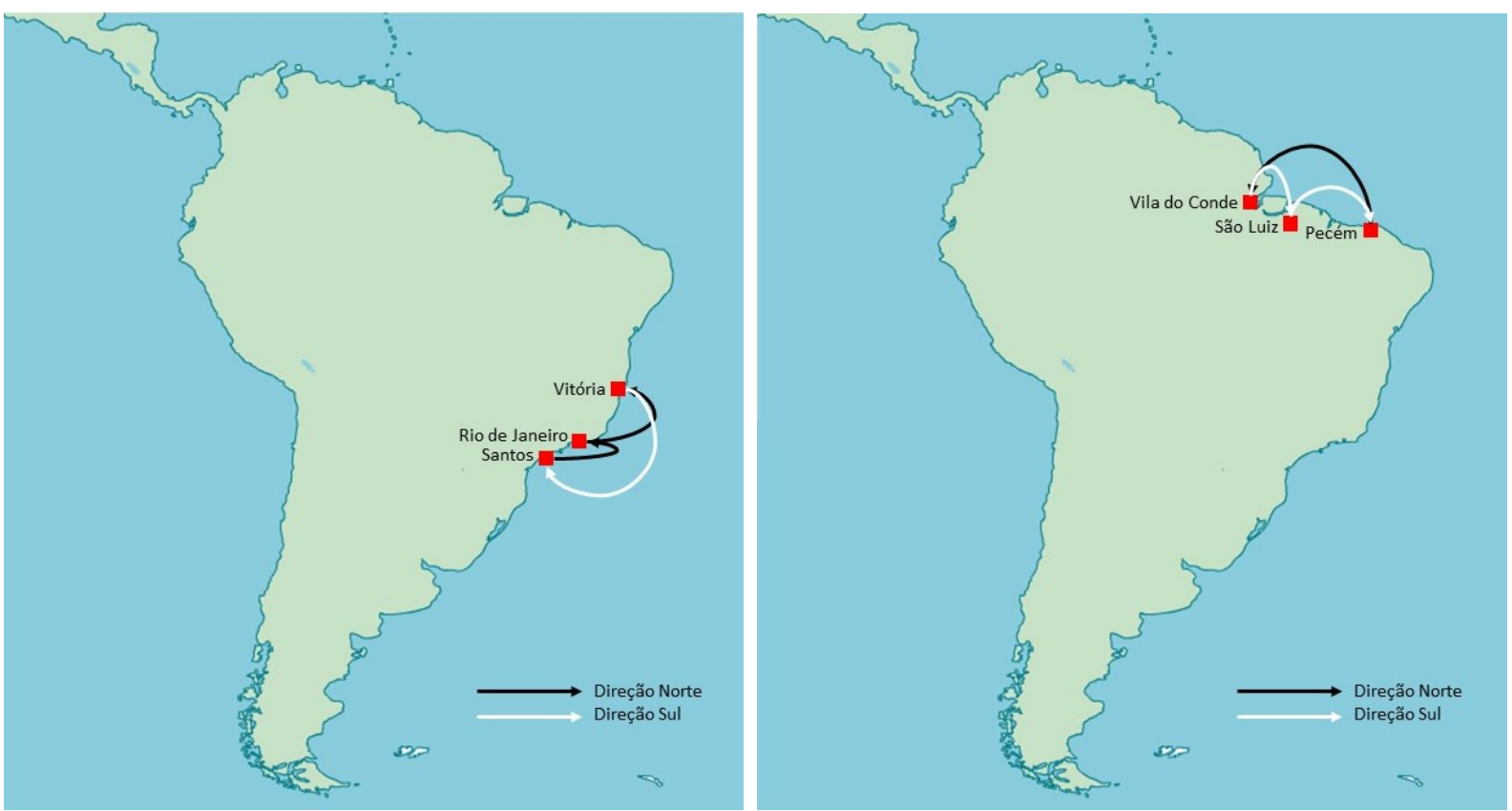

Fonte: Autor 


\subsubsection{Chegada, Atracação e Desatracação}

Cada anel é um sistema fechado, em que as escalas se repetem ciclicamente, enquanto o anel existir na determinada configuração. De maneira mais minuciosa, cada operações em um porto também segue um sequenciamento de processos padronizado, que se faz necessário estudar para o correto modelamento do sistema, já que estes processos também são cíclicos e se repetem a cada escala.

Para melhor entender os processos que ocorrem em cada porto, estes serão separados em duas localidades, denominadas barra portuária, local junto à costa marítima onde as embarcações aguardam em fila a autorização para atracação, exemplificado na figura 12, e terminal portuário, sítio junto ao qual a embarcação será ancorada para a realização das operações de carga e descarga, apresentado na figura 13.

Figura 12 - Navios enfileirados na barra portuária

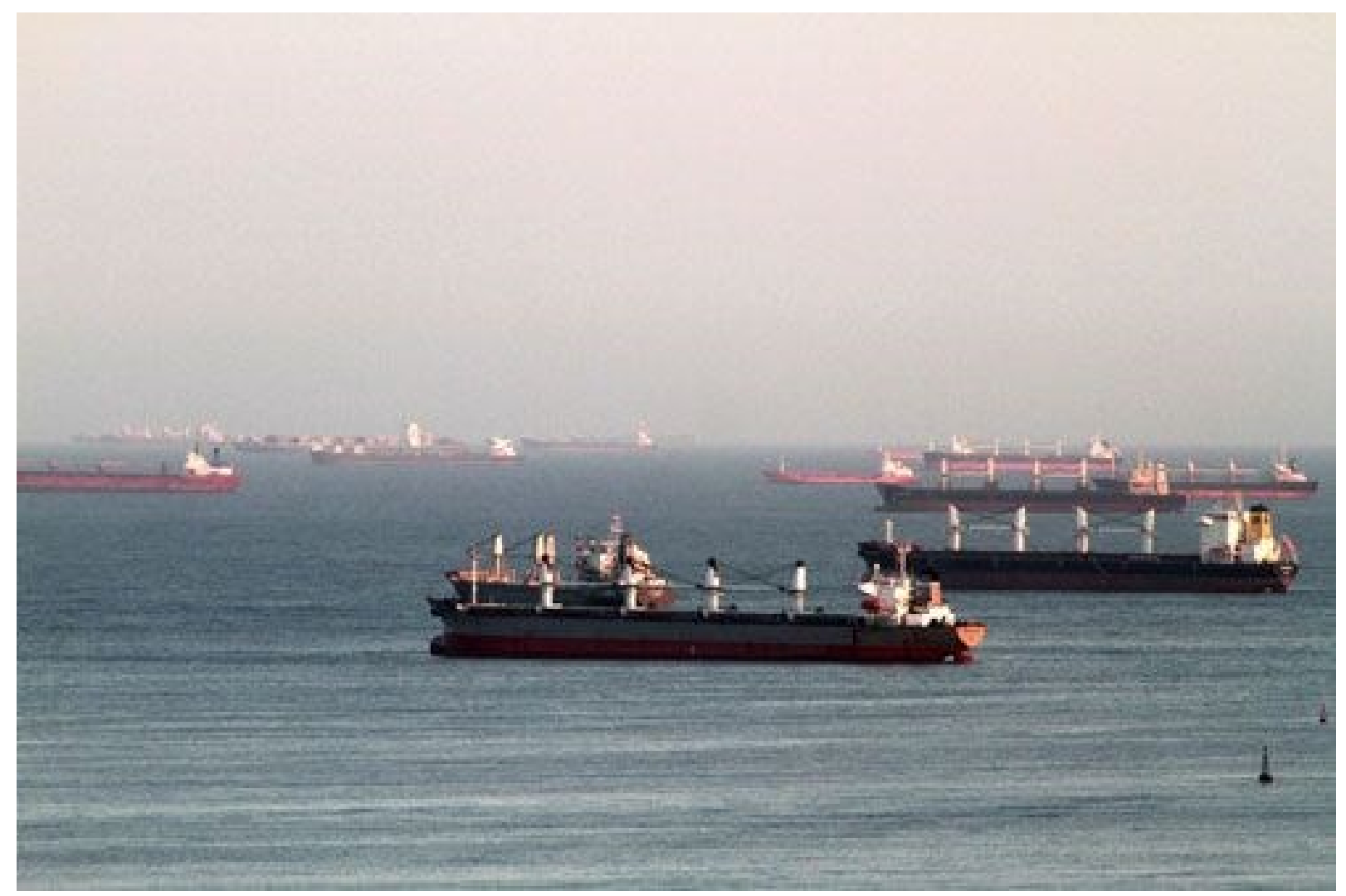

Fonte: Mauri Alexandrino, 2010 
Figura 13 - Terminal de contêineres

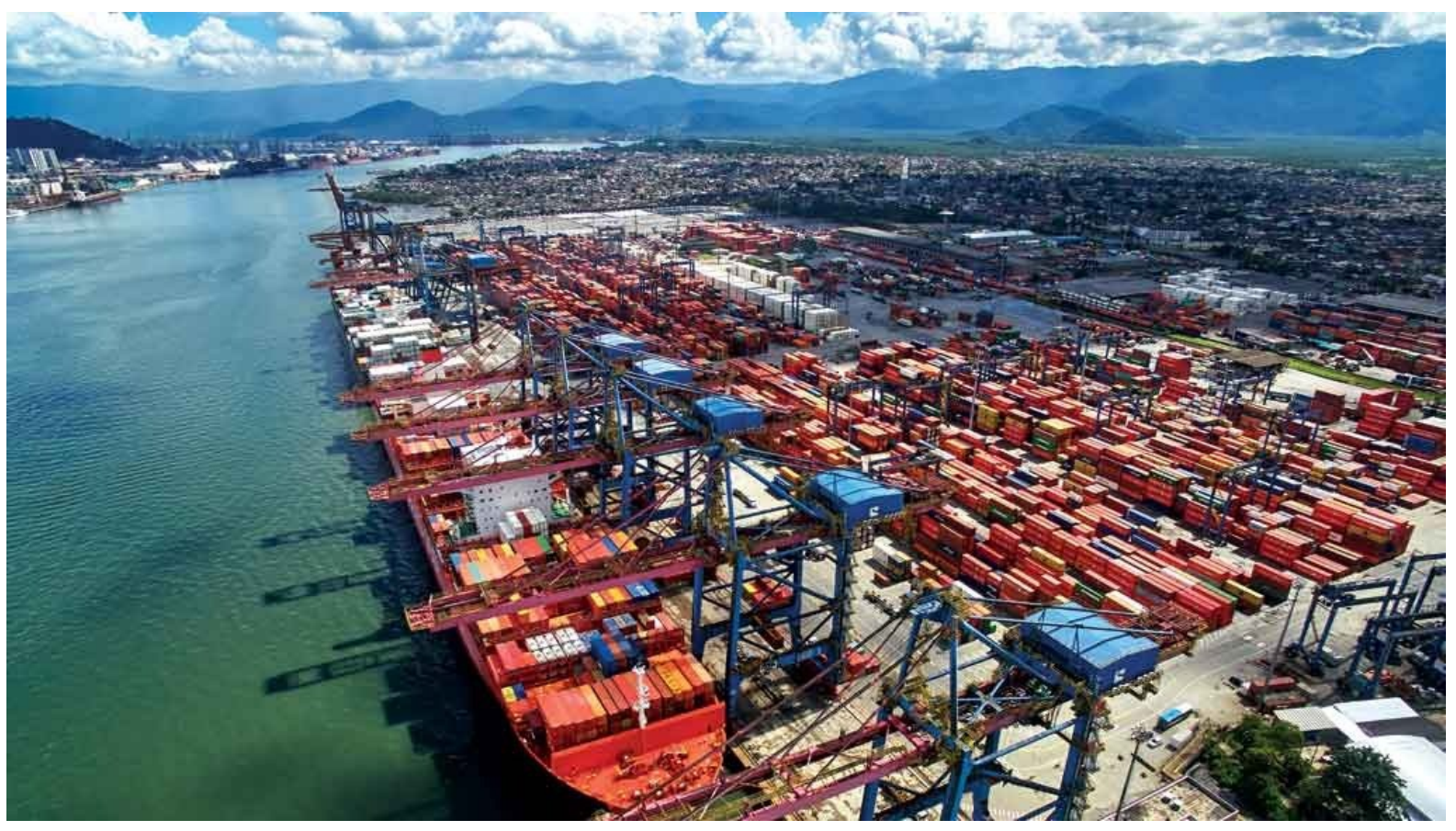

Fonte: Bruno Nunes, 2020

Ao chegar na barra portuária, a embarcação entra em uma fila de espera para atracação, já que os terminais têm capacidade de atendimento limitado e as operações demoram diversas horas. No momento em que há autorização para que a atracação ocorra no terminal préestabelecido, dá-se início à manobra de atracação com a chegada do prático a bordo da embarcação. Este profissional é responsável por auxiliar a manobra, uma vez que se trata de um especialista naquele porto em particular, conhecendo em detalhes o canal de acesso, as tábuas de maré e de ventos da região, garantindo a segurança da operação. O navio, então, adentra as instalações portuárias e navega até sua completa ancoragem junto ao cais do terminal.

Após o término desta manobra, apesar de estar fisicamente apta a receber o início das operações de carga e descarga, é necessário aguardar a liberação das autoridades portuárias para início delas. Assim que liberado pelas autoridades, o terminal inicia o processo de carga e descarga, fazendo uso dos guindastes disponíveis e aptos a serem utilizados para atendimento da embarcação. Ao final de toda a carga e descarga, o processo é finalizado e a embarcação aguarda uma nova autorização das autoridades portuárias para iniciar a manobra de desatracação, que ocorre de maneira similar à atracação, mas com a finalidade de deixar o terminal portuário em direção à barra portuária, também acompanhada por um prático. Ao chegar à barra portuária, o prático retorna às instalações do porto, e o navio segue viagem rumo ao próximo porto da proforma, navegando consoante velocidade por esta estabelecida. Ao 
chegar na barra do próximo porto, o processo retromencionado é repetido, e assim sucessivamente por toda a operação do serviço. A sucessão dos acontecimentos, assim como os respectivos tempos entre etapas são melhor visualizados no esquema apresentado na figura 14 .

Figura 14 - Sequência de operações portuárias

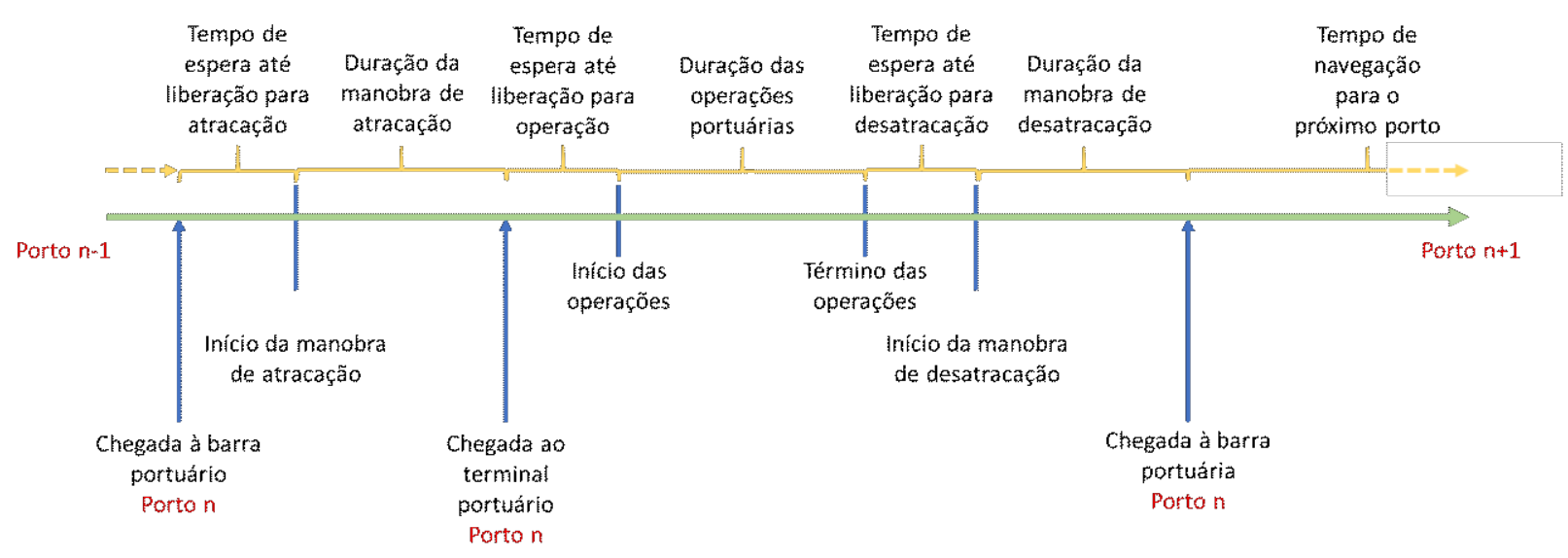

Fonte: Autor

\subsubsection{Janelas de Atracação}

Ao chegarem na barra de atracação, as embarcações estão sujeitas à fila de atracação, de acordo com a ordem de chegada no local, o que pode causar severos atrasos, principalmente em portos com alto tráfego. A fim de evitar este inconveniente, é prática comum na indústria a instauração de janelas de atracação (CHUNG; CHIANG, 2011). Estas janelas consistem em um período pré-estipulado junto ao terminal, dentro do qual determinada embarcação tem prioridade de atracação sobre todas as outras da fila. Segundo Chung e Chiang (2011), o correto posicionamento das janelas tem importância fundamental para a garantia de uma proforma confiável. Vernimmen, Dullaert e Engelen (2007) afirmam que muitas companhias não planejam tempo suficiente para suas janelas por considerarem um buffer muito custoso, o que incorre em muitos atrasos se, por qualquer motivo, o navio não atender a janela de atracação, voltando à fila usual.

Durante o planejamento da proforma, são iniciadas as negociações com os terminais para alocação das janelas requeridas. Devido ao fato de estas instalações terem capacidade limitada e atenderem muitas empresas e seus serviços, conseguir janelas de atracação adequadas pode não ser tarefa das mais simples, por isso a negociação se inicia com bastante antecedência. 
Também em consequência desta elevada demanda, concedem-se apenas algumas horas de janelas para os armadores, possibilitando uma maior quantidade de janelas por dia.

No serviço de Cabotagem analisado neste trabalho, as janelas de atracação negociadas entre o armador e os respectivos terminais portuários perfazem 7 horas semanais, sendo que sua abertura ocorre uma hora antes do horário nominal de atracação (aquele determinado na proforma) e o fechamento acontece 6 horas após este horário, como mostra o esquema apresentado na figura 15.

Figura 15 - Janela de atracação de 7 horas

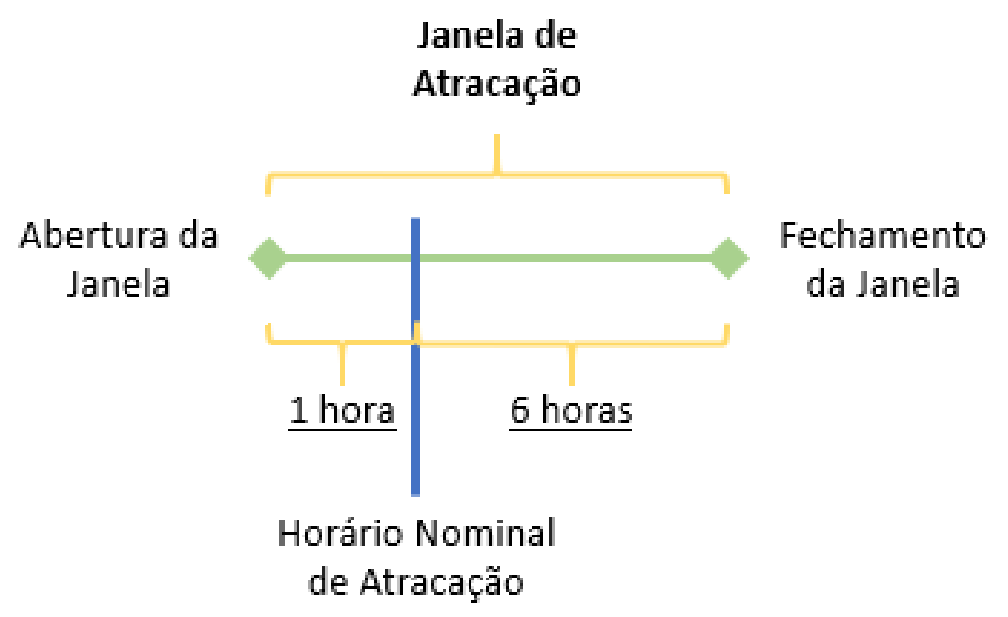

Fonte: Autor

Conforme supracitado, quando uma embarcação chega em determinada instalação portuária dentro de sua janela de atracação, é concedida a ela prioridade. Assim, a manobra de atracação é iniciada de imediato, salvo se, por razões extraordinárias, o terminal não tenha capacidade de receber este navio em seu cais, por exemplo, por desativação temporária dos equipamentos ou por atraso na operação da embarcação anterior, ocupando o espaço destinado à recém chegada. Como estes eventos não ocorrem com frequência, foi adotada, por efeito de simplificação do modelo, a hipótese de que a chegada do navio dentro de sua janela representa sempre uma atracação imediata.

A chegada fora da janela de atracação pode ocorrer em dois momentos distintos: antes de sua abertura ou depois de seu fechamento. Quando a primeira situação acontece, a decisão mais comum é aguardar a abertura oficial da janela para então proceder com a operação. Isto se deve ao fato de que, quando a programação de um determinado serviço é publicada, duas 
importantes datas são divulgadas: a atracação em si e uma data corte para recebimento de cargas para esta escala, estabelecida como 24 horas antes do embarque. Os clientes deste armador programam suas cadeias produtivas e logísticas para atender estes horários e qualquer antecipação por parte do armador atinge efeitos tão desastrosos como os atrasos, incorrendo em custos para todos os envolvidos (NOTTEBOOM, 2006). Já quando a chegada acontece após o fechamento da janela, a embarcação entra na fila de atracação e fica sujeita à quantidade de navios aguardando liberação para operação. Nesta situação, são avaliados os impactos da espera pela atracação ou cancelamento da escala, sendo o segundo bastante frequente, por representar um menor impacto geral na confiabilidade do serviço. Existem, ainda, conceitos muito aplicados em Tramp e Industrial Shipping, conhecidos como Demurrage e Detention, nos quais são aplicadas taxas de sobreestadia ao cliente ou ao terminal portuário em decorrência de atrasos na operação dos navios por fatores alheios ao armador. Em Liner Shipping, porém, são pouco frequentes cobranças relacionadas a atrasos das embarcações, uma vez que as escalas acontecem de maneira regular nos portos pré-estabelecidos pela proforma. São observados, nesta última modalidade, apenas a aplicação de taxas de sobreestadia relacionados à devolução retardada de contêineres ou à detenção prolongada antes do embarque dos mesmos.

Devido à dificuldade inerente ao modelamento da fila, que apresenta dinamismo e imprevisibilidade, adotou-se neste trabalho uma estratégia mais conservadora, em que a decisão é sempre realizar a omissão da escala caso o navio chegue após o fechamento de sua janela. Caso a chegada ocorra antes da abertura dela, segue-se a prática real, ou seja, é aguardada a abertura oficial da janela. Faz-se necessário, contudo, estabelecer um limite aceitável para que a embarcação aguarde por sua janela oficial. Ainda seguindo as práticas adotadas pela empresa operadora deste serviço de Cabotagem, estabeleceu-se o limite de 36 horas antecedentes à escala nominal, dentro das quais a embarcação aguardará a abertura de sua janela oficial para então proceder à atracação. Caso a chegada ocorra antes destas 36 horas, a escala é suprimida e a embarcação segue rumo ao próximo porto.

Vale destacar que, ao adotar a estratégia ora mencionada, privilegia-se a manutenção da confiabilidade da programação, uma vez que há uma tendência de correção para que a atracação ocorra sempre dentro da janela estipulada. Considera-se, ainda, que a decisão pela supressão unânime de escalas quando a chegada ocorre a posteriori, embora não seja totalmente alinhada à prática real, representa uma poderosa ferramenta para identificação de escalas problemáticas, pois estas serão sistematicamente suprimidas na simulação, urgindo a necessidade de readequação do planejamento, atingindo os objetivos do modelo. Ainda, como o objetivo deste modelo não é verificar a melhor condição financeira para companhia, mas sim visualizar 
tendências de problemas operacionais com foco exclusivo na pontualidade, considera-se que, embora perigosa, esta premissa pode ser adotada sem prejuízo neste modelo, não sendo adequada para análises que envolvam arbitragens monetárias.

Existem, entretanto, algumas exceções, cruciais devido a importância de alguns portos nos anéis que estão inseridos. Manaus no anel 1, por exemplo, é o porto principal do serviço e jamais terá sua escala cancelada, mesmo que haja um atraso considerável para que ela ocorra. Assim, as lógicas acima descritas foram retrabalhadas de modo que as situações em que haveria omissão de escala, ou seja, quando o navio chega após o fechamento da janela e até 36 horas antes da abertura da mesma, a escala aconteça imediatamente. Embora esta prática não reflita com exatidão a realidade, faz-se necessário utilizar este artifício devido à dificuldade de modelamento da fila de atracação. Novamente, reitera-se que esta simplificação não apresenta prejuízo a este modelo, devido a seu foco exclusivo na pontualidade, sem inclusão de aspectos financeiros. Além de Manaus, as escalas de Vitória no anel 4, Pecém e Vila do Conde no anel 6 também foram consideradas da mesma forma, pelo mesmo motivo. Estes casos foram, inclusive, monitorados individualmente, pois uma frequência muito elevada desta situação também representa uma necessidade latente por adaptações e revisões no serviço.

Nesta simulação, as janelas de atracação foram estabelecidas como variáveis JanX, sendo $\mathrm{X}$ o porto ao qual a janela se refere, assumindo os valores 0 para o momento pré-janela, delimitado pelas 36 horas antes do horário previsto para atracação, 1 para o período em que a janela encontra-se aberta e 2 para o período em que ela acha-se fechada, um processo que se repete ciclicamente, acompanhando a frequência estabelecida pelo serviço. Visto que todos os anéis deste serviço apresentam frequência semanal, a janela de atracação de cada porto se abre uma vez por semana, para cada anel que o escalará, sempre no mesmo dia e horário estabelecido por cada proforma. A figura 16 demonstra o ciclo de transformação da variável JanX ao longo de uma semana genérica $\mathrm{N}$, na qual percebe-se que a soma das quantidades de tempo em que ela assume seus três valores possíveis perfazem as 168 horas contidas em uma semana. 
Figura 16 - Ciclo de transformação da variável JanX

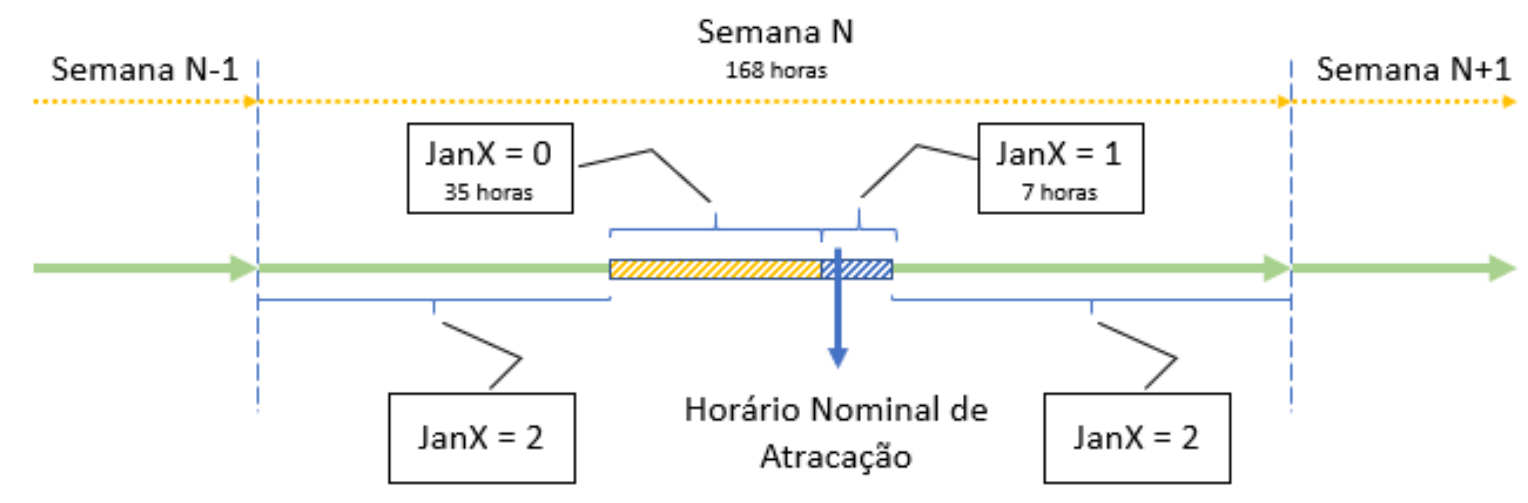

Fonte: Autor

Referenciando a meia noite da segunda-feira como o marco inicial da semana, foram estabelecidas sub-rotinas que alteram os valores das diversas variáveis JanX de acordo com o esquema acima demonstrado, até o limite de 168 horas, momento em que se completa uma semana e os valores originais das variáveis são restabelecidos, reiniciando o ciclo. No Apêndice B, visualizam-se as janelas de todos os portos de cada anel, dispostos ao longo dos dias da semana e seguindo a nomenclatura acima estabelecida.

\subsubsection{Operação e Produtividade Portuária}

Ao receber autorização para atracação, inicia-se a manobra de aproximação ao terminal, assistida por um prático e, por vezes, por um ou mais rebocadores, embarcações especiais que ajudam na manobra de aproximação do navio contra o cais. Na maioria dos portos brasileiros, esta manobra é efetuada em aproximadamente 1 hora, exceto alguns portos com canal de acesso mais complicado ou extenso, como é caso do Sepetiba Tecon, localizado dentro da baía de Sepetiba. Tanto a manobra de atracação quando a de desatracação são manobras diretas, que apresentam pouca variabilidade de duração. Devido à dificuldade de coleta de dados relacionados aos tempos de manobra e tendo em vista sua baixa influência como fator causador de atrasos (CHUNG; CHIANG, 2011), decidiu-se manter o dado determinístico da proforma.

Ao finalizar a atracação, o navio recebe a visita dos agentes da autoridade portuária local, bem como de agentes da vigilância sanitária, com intuito de fiscalizar a documentação da embarcação, das autorizações concedidas pelas autoridades para atracação e operação naquele terminal e das condições sanitárias a bordo. Ao final deste processo, é emitida a autorização para início das operações de carga e descarga. Este tempo de espera pré-operação para 
fiscalização das autoridades é bastante específico para cada porto e apresenta grande variabilidade entre diferentes escalas no mesmo local. Por isto, foram estabelecidas variáveis WaitPreX, sendo $\mathrm{X}$ o porto no qual a operação está acontecendo, que assumem valores aleatórios seguindo distribuições estatísticas, coletadas a partir de dados históricos de operações dos navios deste serviço. Devido a peculiaridade de cada porto, os levantamentos estatísticos foram feitos para cada porto, operando em cada anel diferente.

Ao término da operação, é realizada uma segunda fiscalização e novos documentos são analisados, incorrendo em um segundo tempo de espera, também bastante específico, de comportamento independente em relação ao tempo pré-operação e com grande variabilidade entre escalas. Seguindo a mesma metodologia adotado para a medida anterior, estabeleceramse as variáveis WaitPos $X$, ainda com $\mathrm{X}$ equivalendo ao porto de operação, que também assumem valores arbitrários consoante a distribuição estatística coletada a partir dos dados históricos de operação, de modo análogo à variável do parágrafo anterior.

Por último, o tempo de operação de carga e descarga é, por sua vez, dependente de duas outras variáveis: volume movimentado e produtividade do terminal portuário. A primeira delas é de difícil previsão, pois dependem de fatores econômicos, como demanda e sazonalidade, fatores operacionais, como a capacidade produtiva das fábricas deste determinado cliente, e até mesmo logísticos, como a capacidade de escoamento da produção até os portos de embarque, gerando grande imprevisibilidade acerca do volume a ser movimentado. Vale lembrar que, como os serviços destinados à Cabotagem são concomitantemente feeders dos volumes destinados a importação e exportação, esta imprevisibilidade é potencializada por fatores internacionais também, aumentando ainda mais a complexidade desta previsão.

Para cada instalação portuária, foi estabelecida uma variável VolX, sendo X o porto em que a operação ocorrerá, que assumem valores aleatórios também baseados em curvas estatísticas levantadas a partir de dados históricos dos últimos 2 anos. Em função da alta influência da sazonalidade nos volumes transportados, estabeleceram-se curvas específicas para cada trimestre, possibilitando a discretização deste efeito ao longo da simulação. Assim, reescreve-se a variável relacionada ao volume como VolXT, em que X continua sendo o porto em que a operação ocorrerá e T se refere ao trimestre em que se encontra a data da escala.

Além do volume de contêineres, uma segunda movimentação é levada em consideração, que é a de remoção dos tampões dos porões do navio. Este volume não apresenta relação direta com o volume carga a ser movimentado, e por isso dispensa o levantamento estatístico detalhado por trimestre. Assim, estabeleceram-se as variáveis $\mathrm{HCx}$, provenientes do termo em 
inglês Hatch Cover, sendo x o porto em que a operação ocorrerá, também baseadas em informações históricas e modeladas com curvas de distribuição estatísticas.

Escreve-se o volume total movimentado como:

$$
\operatorname{Vol}_{T T L}=\operatorname{VolXT}+H C x
$$

Analisando-se o modelo proposto por Tongzon (1995), algumas adaptações se fazem relevantes o modelo aqui proposto. Primeiramente, visualiza-se que o intuito daquele estudo era determinar a produtividade baseada em TEUs, ou seja, contêineres de 20 pés, daí a necessidade da variável CONMIX, convertendo as unidades de 40 pés em 2 TEUs cada. Devido ao fato de que esta simulação foi realizada completamente com base em unidades movimentadas, não faz diferença, na prática, se o contêiner é de 20 ou 40 pés. Assim, esta variável foi suprimida. A segunda variável da equação apresentada diz respeito ao atraso préoperacional, outrora especificado (PreOpX). Portanto, descarta-se, também, a variável BRLWT, já incluída no modelo.

Em seguida, verifica-se que as variáveis GWLN, CHWH e CE apresentam íntima relação, pois tratam da disponibilidade e alocação de guindastes durante a operação. CHWH e GWLN indicam, respectivamente, a porcentagem de utilização dos guindastes alocados na operação e o tempo de atraso durante a operação, ou seja, tempo no qual a utilização do guindaste em questão foi nula. CE, por sua vez, se refere ao tamanho da embarcação e do volume a ser movimentado, grandezas que são diretamente proporcionais à quantidade de guindastes alocados durante a operação. Quanto maior o navio, mais guindastes simultâneos podem operá-lo. Com isso, julga-se conveniente a simplificação destas três variáveis, combinando-as em uma quarta chamada denominada AvgCraneX, que retrata a quantidade média global de guindastes utilizados durante a operação, já incluindo atrasos e troca de equipamentos.

Por fim, a variável TEUCH é mantida, pois se refere à média de produtividade individual de cada guindaste, que depende do tipo de guindaste utilizado, sendo o STS mais ágil em relação ao MHC, do estado de conservação dos mesmos, além de fatores logísticos, como a facilidade de movimentação dos veículos que farão a movimentação das cargas em solo. Esta variável foi reescrita para ProdX, referindo-se à produtividade média individual dos guindastes do terminal $\mathrm{X}$.

Utilizando-se dos dados históricos, foram levantadas as distribuições estatísticas das duas variáveis retromencionadas, para cada porto. Esta produtividade aqui estabelecida não 
contém os tempos de espera pré- e pós-operacionais, sendo, então, denominada de Produtividade FPLP, do inglês First Pick Last Pick, que se refere à medida tomada desde o primeiro contêiner movimentado até o último, isolando quaisquer efeitos de atraso a priori ou a posteriori. Determina-se, então, a Produtividade FPLP (EFPP) como sendo o produto:

$$
E_{F P L P}=\operatorname{ProdX} * \text { AvgCraneX }
$$

O tempo total de operação de um porto X (OpTimeX) é descrito como:

$$
\text { OpTimeX }=\frac{\operatorname{Vol}_{T T L}}{E_{F P L P}}
$$

O esquema apresentado na figura 17 apresenta a operação completa que ocorre no sítio do terminal portuário.

Figura 17 - Operação no terminal portuário

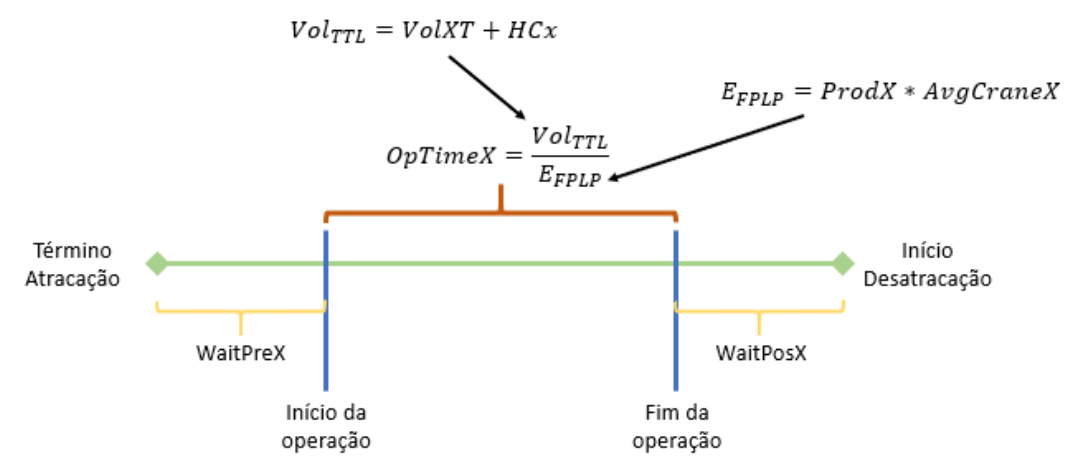

Fonte: Autor

O algoritmo completo de movimentação, unificando as lógicas retromencionadas, é apresentado na figura 17. Por se tratar de uma lógica cíclica, infinita, definiu-se um parâmetro de tempo, após o qual a simulação é encerrada e os dados, coletados. Decidiu-se, então, simular o modelo no período de um ano, tempo suficiente para passar por todas as diversas sazonalidades e garantir que cada navio tenha realizado, ao menos, 10 viagens de 35 dias cada, nos anéis maiores, chegando a 52 viagens nos serviços menores. 
Figura 18 - Lógica completa de movimentação

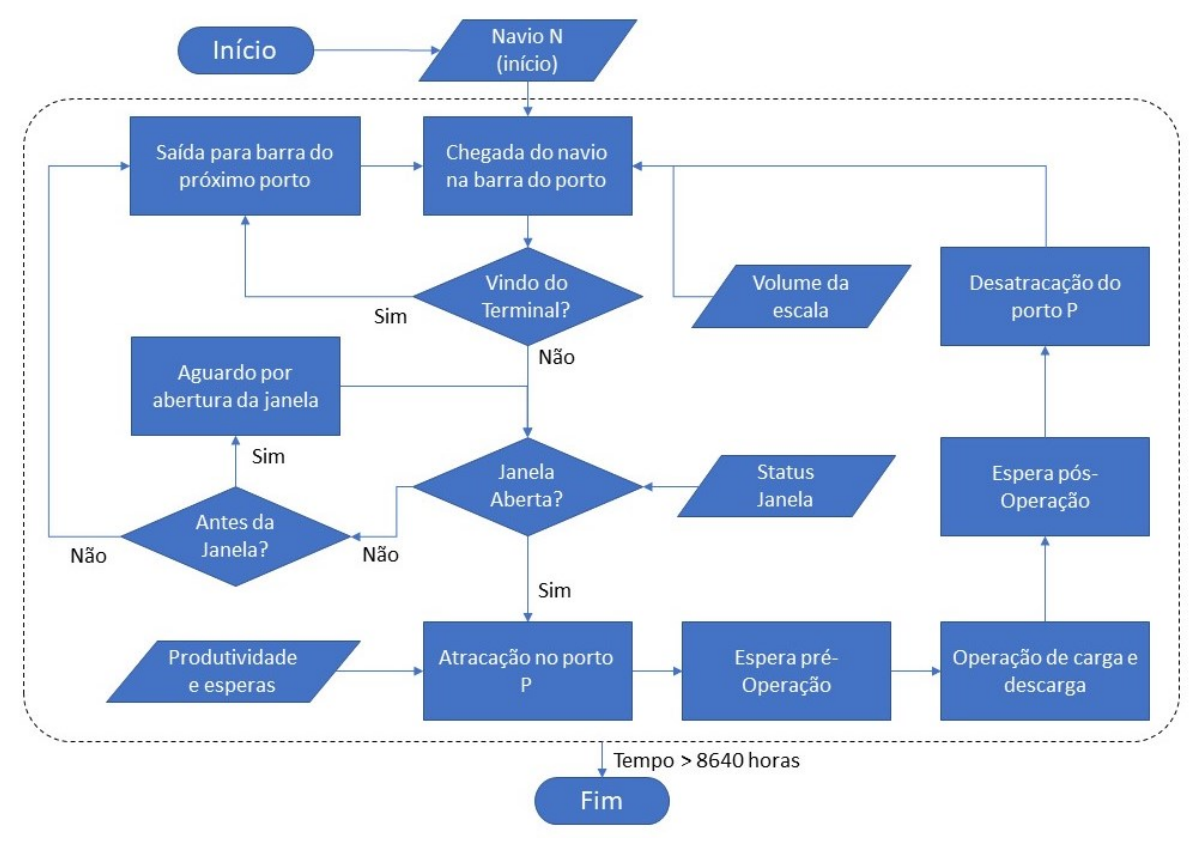

Fonte: Autor

É importante destacar que o modelo não apresenta qualquer consideração de efeitos naturais, como condições meteorológicas ou de maré, ou ainda ocorrências de força maior, como greve, eventuais acidentes, entre outros. Destaca-se, contudo, que estes são fatores importantes a serem mensurados, mas a ausência deles se deve à falta de dados estatísticos confiáveis para serem modelados e à enorme imprevisibilidade dos mesmos. O risco da ausência de tais parâmetros é, por sua vez, limitada, uma vez que não são comuns disrupções operacionais no Brasil devido a estes fatores.

\subsubsection{Dados de Entrada}

Após a finalização do modelo, faz-se necessário alimentá-lo com estatísticas adequadas, que garantam a fidelidade dos números ao sistema real. Para tanto, foram coletados dados de todas as escalas dos navios de Cabotagem no período de 2 anos, totalizando pouco mais de 3,5 mil registros. Os dados coletados consistem do porto e terminal operados, a respectiva viagem e sua direção, os horários de chegada e saída do porto, início e fim das operações e obtenção da autorização para início das operações. Além disso, foram coletadas as quantidades de contêineres e hatch covers movimentados, assim como a quantidade de guindastes utilizados, o tempo em que cada um permaneceu em operação e o período de parada de cada um, caso existente. 
Os dados foram discretizados por direção, uma vez que o fluxo de carga é bastante díspar entre as direções norte e sul, e por terminal portuário, salvo quando há uma troca entre o terminal padrão do serviço por algum outro no mesmo porto, por qualquer motivo. Adicionalmente, os volumes de contêineres foram separados por trimestre, possibilitando a captação dos efeitos de sazonalidade da Cabotagem brasileira, que atinge seu máximo fluxo entre o terceiro e quarto trimestre.

A diferença entre os horários de início das operações, da chegada até a saída do terminal e fim das operações constituem, respectivamente, o tempo de espera pré-operação e o tempo de espera pós-operação. Destaca-se que, entre a chegada da embarcação no terminal portuário e o início das operações há um terceiro momento importante: a autorização das autoridades portuárias para a execução das atividades portuárias, momento não necessariamente simultâneo ao efetivo início das movimentações. Para efeito prático no modelo, contudo, é irrelevante considerar estes dois momentos separadamente, já que ambos representam tempos de espera, permitindo a fusão em um único intervalo.

O tempo despendido entre os momentos de início e término das operações portuárias, ou seja, do período compreendido entre os instantes em que a primeira unidade é movimentada e a última unidade é movida, representa o tempo líquido de operação e é a base para o cálculo da produtividade líquida da operação portuária. Neste intervalo, quaisquer atrasos inerentes à operação dos guindastes são derivados de paradas, momentâneas ou permanentes, de um ou mais equipamentos em uso e, portanto, não foram abatidos do tempo total de operação, mas sim incluídos como ociosidade na métrica de quantidade de guindastes em operação. Por este motivo, verificam-se valores reais para esta variável, que sugere um número inteiro, visto que se trata de uma quantidade concreta de equipamentos em operação.

A tabela 5 apresenta um exemplo dos dados coletados, com a média geral dos portos pertencentes ao anel 1. A decisão pelo modelamento da produtividade global dependendo de duas outras variáveis em detrimento de seu próprio valor histórico é reiterado a partir da comparação entre os 3 primeiros portos da tabela. Embora a produtividade por equipamento varie pouco mais de 5\% entre Santos e Sepetiba, a operação praticamente constante com 3 equipamentos nos dois primeiros portos versus 2 operados em plenitude e mais 1 parcialmente no porto fluminense aumenta em aproximadamente $25 \%$ a eficiência operacional dos portos paulista e catarinense.

Uma segunda estatística importante que pode ser visualizada é a diferença notável entre a produtividade individual dos portos atendidos por guindastes do tipo STS (todos exceto Manaus) e portos operados por MHC (Manaus apenas). O primeiro apresenta um relevante 
ganho de performance operacional, chegando, em alguns casos, a superar o dobro da eficiência do equipamento manauara.

Tabela 5 - Tempos de espera médios e produtividade

\begin{tabular}{cccccccc} 
Porto & $\begin{array}{c}\text { PreOp } \\
\text { (h) }\end{array}$ & $\begin{array}{c}\text { PosOp } \\
\text { (h) }\end{array}$ & $\begin{array}{c}\text { Op } \\
\text { (h) }\end{array}$ & $\begin{array}{c}\text { Prod./Guindaste } \\
\text { (Mov./h) }\end{array}$ & $\begin{array}{c}\text { Guindastes } \\
\text { (Quantidade) }\end{array}$ & $\begin{array}{c}\text { Prod. Média } \\
\text { (Mov./h) }\end{array}$ & $\begin{array}{c}\text { Volume } \\
\text { (Mov./escala) }\end{array}$ \\
\hline Itapoa & 2,69 & 3,35 & 11,43 & 27,36 & 3,06 & 83,39 & 855 \\
Santos & 2,62 & 3,18 & 12,16 & 27,5 & 2,97 & 82,77 & 928 \\
Sepetiba & 4,99 & 2,44 & 12,97 & 26,1 & 2,51 & 65,39 & 600 \\
Salvador & 4,81 & 1,6 & 6,75 & 24,82 & 2,53 & 62,11 & 397 \\
Suape & 1,9 & 1,84 & 11,03 & 24,67 & 2,4 & 58,89 & 595 \\
Pecém & 1,94 & 1,78 & 9,88 & 32,41 & 1,86 & 59,94 & 551 \\
Manaus & 4,45 & 5,28 & 63,38 & 13,8 & 2,82 & 38,86 & 2.271 \\
\hline
\end{tabular}

Fonte: Autor

A simples utilização destas médias, porém, não é adequada, pois os dados sofrem variação ao longo do tempo, perfazendo a necessidade de um levantamento estatístico mais assertivo. Desta forma, para cada um destes conjuntos de dados, para cada escala de cada anel foi levantada uma curva de distribuição estatística e sua respectiva função de distribuição, e escolhida aquela que melhor representasse o conjunto de dados em questão. Ao todo, foram coletadas 297 distribuições estatísticas: espera pré e pós-operação, quantidade de guindastes e produtividade por guindaste, volume de hatch covers movimentados e volumes trimestrais, para cada uma das 33 diferentes escalas operadas pelos 5 anéis modelados. A visualização completa dos dados estatísticos pode ser encontrada no Apêndice C.

\subsubsection{Consumo de Combustível}

O consumo de combustível é um dos parâmetros mais importantes em um sistema de navegação, uma vez que pode representar até $60 \%$ do custo total do serviço, a depender dos navios empregados e da rota navegada.

Como mencionado na literatura, o consumo de combustível pode ser relacionado à velocidade de navegação através de uma equação polinomial de terceiro grau, a qual demonstra que, quanto menor a velocidade de navegação, menor será o consumo de combustível. Há, contudo, um limite para redução de velocidade de navegação, estabelecido pelo próprio propulsor: por se tratar de motores de combustão interna, existe uma velocidade mínima de funcionamento específico para cada motor, abaixo da qual o funcionamento se torna demasiado irregular, promovendo ações nocivas como elevação da temperatura interna e carbonização, 
dizimando a vida útil da máquina. Em marcha lenta, o consumo destes motores é mais elevado, tendendo a cair nos primeiros aumentos de rotação, devido às otimizações de fluxo de ar e estratégias de mistura, atingindo um vale, em que se obtém a melhor relação entre a velocidade do propulsor, sua geração de potência e seu consumo de combustível. A esta velocidade dá-se o nome, em inglês, de ecospeed, ou seja, a velocidade de maior eficiência energética do propulsor.

É prática comum na indústria a adoção da ecospeed em diversos trechos de navegação, devido ao benefício econômico e ambiental que esta proporciona, limitando os deslocamentos a velocidades mais elevadas para momentos essenciais para o bom funcionamento do serviço. Vale lembrar, ainda, que a velocidade final de deslocamento não somente é fruto da força propulsora fornecida pela unidade motriz da embarcação, como também é acrescida da velocidade vetorial da correnteza do meio aquático. Assim, muitas vezes, para que o deslocamento do navio aconteça na velocidade prevista pela proforma, faz-se necessário aumentar ou diminuir a potência do motor, a depender da grandeza vetorial da velocidade da corrente. Um exemplo desta influência é o atendimento ao porto de Manaus, através do Rio Amazonas. Caso seja exigido pela proforma que ambos os deslocamentos de ida e volta de Manaus tenham durações similares, é exigida na ida maior potência do motor do que no retorno, pois, como a corrente do rio é direcionada ao oceano, a subida do rio é prejudicada enquanto a descida é auxiliada por este fenômeno.

O modelamento das curvas de consumo foi realizado a partir do levantamento teórico dos dados de consumo de cada classe de navios utilizados no sistema. A classe de uma embarcação é entendida como o projeto do qual ela foi originada. Como os projetos de embarcações são longos e custosos, diversos navios iguais são construídos a partir de um mesmo projeto, constituindo uma classe específica. O serviço de cabotagem aqui estudado é atendido por 11 navios próprios e 1 terceiro, sendo o primeiro grupo composto por embarcações de 7 diferentes classes.

Para cada classe, foi levantada por intermédio do sistema de gerenciamento técnico dos navios a nuvem de pontos correspondente ao consumo de combustível, em toneladas por hora, para cada velocidade de navegação, medida em nós, e altura de calado, em metros. Esta última medida é também uma importante variável, pois ela influencia no arrasto aerodinâmico do navio com o meio, já que, quanto maior o calado, também maior o arrasto e, por sua vez, o consumo de combustível, para a mesma velocidade. A tabela 6 apresenta um trecho do levantamento realizado para os navios de uma determinada classe. 
Tabela 6 - Consumo de combustível (ton/h) versus velocidade versus altura do calado

\begin{tabular}{|c|c|c|c|c|c|c|c|c|c|c|c|}
\hline & & & & & & & & & & & \\
\hline & & 8,0 & 8,5 & 9,0 & 9,5 & 10,0 & 10,5 & 11,0 & 11,5 & 12,0 & 12,5 \\
\hline Vel. (nós) & 9,00 & & & & & & & & & & 16,8 \\
\hline & 9,25 & & & 16,9 & 16,8 & 16,7 & & & 16,8 & 17,0 & 17,4 \\
\hline & 9,50 & 17,2 & 17,4 & 17,6 & 17,5 & 17,3 & 17,3 & 17,3 & 17,4 & 17,6 & 18,1 \\
\hline$\downarrow$ & 9,75 & 17,9 & 18,1 & 18,3 & 18,2 & 18,0 & 18,0 & 17,9 & 18,1 & 18,3 & 18,9 \\
\hline & 10,00 & 18,7 & 18,9 & 19,1 & 18,9 & 18,7 & 18,7 & 18,6 & 18,8 & 19,1 & 19,6 \\
\hline & 10,25 & 19,6 & 19,7 & 19,9 & 19,7 & 19,5 & 19,4 & 19,4 & 19,6 & 19,8 & 20,4 \\
\hline & 10,50 & 20,5 & 20,6 & 20,7 & 20,5 & 20,2 & 20,2 & 20,1 & 20,3 & 20,6 & 21,3 \\
\hline & 10,75 & 21,4 & 21,5 & 21,6 & 21,4 & 21,0 & 21,0 & 20,9 & 21,2 & 21,4 & 22,2 \\
\hline & 11,00 & 22,4 & 22,5 & 22,5 & 22,2 & 21,9 & 21,8 & 21,8 & 22,0 & 22,3 & 21,9 \\
\hline & 11,25 & 22,2 & 22,3 & 22,3 & 22,0 & 22,7 & 22,7 & 22,6 & 22,9 & 22,0 & 22,9 \\
\hline & 11,50 & 23,3 & 23,3 & 23,3 & 22,9 & 22,4 & 22,4 & 22,4 & 22,6 & 23,0 & 23,9 \\
\hline & 11,75 & 24,4 & 24,4 & 24,3 & 23,8 & 23,3 & 23,3 & 23,3 & 23,6 & 23,9 & 24,9 \\
\hline & 12,00 & 25,5 & 25,4 & 25,3 & 24,8 & 24,3 & 24,3 & 24,2 & 24,6 & 24,9 & 26,0 \\
\hline & 12,25 & 26,6 & 26,5 & 26,3 & 25,8 & 25,2 & 25,2 & 25,2 & 25,6 & 26,0 & 27,1 \\
\hline & 12,50 & 27,8 & 27,6 & 27,4 & 26,8 & 26,2 & 26,2 & 26,2 & 26,6 & 27,0 & 28,2 \\
\hline & 12,75 & 28,9 & 28,7 & 28,4 & 27,8 & 27,2 & 27,2 & 27,3 & 27,7 & 28,2 & 29,4 \\
\hline & 13,00 & 30,1 & 29,8 & 29,5 & 28,9 & 28,2 & 28,3 & 28,3 & 28,8 & 29,3 & 30,6 \\
\hline
\end{tabular}

Fonte: Autor

Devido à natureza cúbica da função que relaciona velocidade e consumo, uma mera interpolação linear da velocidade da proforma para obtenção do respectivo consumo não é adequada tecnicamente, embora tal recurso não leve a erros grandes, dada a grande discretização dos pontos. Solução tecnicamente mais precisa é o uso da regressão polinomial, utilizando os dados das tabelas obtidas através do sistema operacional dos navios para obtenção das funções polinomiais de terceiro grau que as caracterizam e seus parâmetros. Levantou-se, para cada altura de calado, a respectiva curva característica e seus parâmetros, que foram utilizados posteriormente para o cálculo do consumo horário de cada trecho navegado, a partir da velocidade estabelecida na proforma e baseado no calado médio histórico do trecho analisado. Por fim, foi obtido o consumo total de cada trecho através da multiplicação do consumo horário pelo tempo navegado, derivado da distância e da velocidade de deslocamento do trecho.

Como cada trecho pode ser atendido por mais de uma diferente classe de embarcação, o cálculo é efetuado para todas, de modo a estabelecer um banco genérico de consumo por trecho. Esta visualização não somente favorece a intercambialidade de navios entre os diferentes anéis do serviço, como também enriquece a comparação entre os diferentes tipos de navios, pois torna apta a visualização da grande diferença de consumo entre eles, para um mesmo trecho e velocidade. Um sumário, para as principais rotas do anel 1, é apresentado na 
tabela 7, com as 4 principais classes atualmente operando neste sistema. Nota-se a evidente disparidade entre o elevado consumo da classe 3 versus o bastante atrativo gasto da classe 4 , tendo as demais um patamar intermediário. Embora seja composta de embarcações maiores, a classe 3 é também a mais antiga delas, com tecnologia já defasada, que corrobora para os baixos índices de consumo. Em contrapartida, a classe 4, mais recente, tem embarcações similares aos da classe 1 em tamanho, porém atinge médias insuperáveis de consumo.

Tabela 7 - Consumo por trecho e classe de navio

\begin{tabular}{|c|c|c|c|c|c|c|c|c|}
\hline \multirow[b]{2}{*}{$\begin{array}{l}\text { Porto de } \\
\text { Origem }\end{array}$} & \multirow[b]{2}{*}{$\begin{array}{c}\text { Porto de } \\
\text { Destino }\end{array}$} & \multirow[b]{2}{*}{$\begin{array}{c}\text { Navegação } \\
\text { (h) }\end{array}$} & \multirow[b]{2}{*}{$\begin{array}{c}\text { Distância } \\
\text { (mn) }\end{array}$} & \multirow[b]{2}{*}{$\begin{array}{l}\text { Velocidade } \\
\text { (nós) }\end{array}$} & \multicolumn{4}{|c|}{ Consumo } \\
\hline & & & & & $\begin{array}{c}\text { Classe } 1 \\
\text { (ton/h) }\end{array}$ & $\begin{array}{l}\text { Classe } 2 \\
\text { (ton/h) }\end{array}$ & $\begin{array}{l}\text { Classe } 3 \\
\text { (ton/h) }\end{array}$ & $\begin{array}{l}\text { Classe } 4 \\
\text { (ton/h) }\end{array}$ \\
\hline Itapoa & Santos & 13,1 & 165 & 12,6 & 20,3 & 21,5 & 30,3 & 15,1 \\
\hline Santos & Sepetiba & 11,0 & 147 & 13,4 & 18,3 & 20,4 & 26,9 & 13,7 \\
\hline Sepetiba & Salvador & 53,0 & 794 & 15,0 & 97,9 & 125,1 & 149,5 & 84,2 \\
\hline Salvador & Suape & 26,0 & 356 & 13,7 & 42,7 & 50,9 & 64,9 & 34,0 \\
\hline Suape & Pecém & 27,0 & 457 & 16,9 & 67,2 & 84,3 & 96,5 & 53,5 \\
\hline Pecém & Macapá & 56,0 & 705 & 12,6 & 85,0 & 92,9 & 123,6 & 63,5 \\
\hline Macapá & Manaus & 56,2 & 708 & 12,6 & 85,4 & 93,3 & 124,2 & 63,8 \\
\hline
\end{tabular}

Fonte: Autor 


\section{SIMULAÇÃO E RESULTADOS}

"A lógica te levará do ponto $A$ ao ponto B. A imaginação te levará para todos os lados."

(Albert Einstein)

O modelo teórico supracitado foi convertido em modelo computacional utilizando o software Promodel ${ }^{\circledR}$, no qual os 5 anéis do serviço foram estabelecidos, com seus respectivos portos, navios e lógicas de movimentação. Para um melhor controle da simulação e facilidade na alteração de parâmetros, a maior parte dos dados de entrada do modelo foram vinculados às planilhas eletrônicas do MS Excel ${ }^{\circledR}$.

Frequentemente, quando um novo serviço é estabelecido, seus navios já estão empregados em outro serviço, ou ainda no mesmo, mas em outra configuração. Assim, definese a primeira escala efetiva da nova configuração e o navio que realizará esta escala inaugural. A partir desta primeira escala, o navio piloto segue a nova programação e as demais, uma a uma, completam o ciclo faltante no serviço antigo até realizarem a transferência para o novo setup. Esta troca, conhecida como phase-in (entrada) e phase-out (saída), acontece preferencialmente em portos comuns a ambas as configurações, minimizando o impacto de transferência de cargas do serviço antigo para um determinado porto de descarga não mais escalado.

Nesta simulação, contudo, não existia um serviço prévio em que os navios estavam empregados. Desta forma, para caracterizar a passagem e o início adequado do serviço, foi determinado um parâmetro de chegada para cada embarcação de 12 horas antes da abertura da janela de atracação do primeiro porto do ciclo, estabelecido aqui como o porto de phase-in. Com isso, garantiu-se o perfeito início do serviço, como usualmente ocorre em uma mudança de configuração real ou iniciação de um novo anel.

Todas as simulações foram conduzidas no intervalo de 8760 horas, equivalente aos 365 dias do ano convertidos em horas, visto que este serviço não tem nenhuma parada programada ao longo do ano.

\subsection{PRIMEIRA SIMULAÇÃO E VALIDAÇÃO DO MODELO}

Após o completo modelamento do sistema no software Promodel ${ }^{\circledR}$, foi realizada uma primeira simulação completa do sistema, ainda baseada nos parâmetros determinísticos 
provenientes das próprias proformas. Esta etapa é de fundamental importância na validação do modelo, pois garante a aderência do modelo computacional ao sistema real e valida as lógicas aplicadas durante a programação do mesmo. Dado o fato de utilizar dados determinísticos na simulação, era esperado que não houvesse qualquer alteração de parâmetros, seja de entrada ou de saída, ao longo desta primeira experiência, assim como foi previsto que todas as embarcações chegariam aos portos poucas horas antes da respectiva abertura de janela de atracação, mantendo o ciclo constante e regulado. Foi, também, suposta a ausência de qualquer omissão de escala ou aumento no monitor de atracação fora de janela, especificamente para os portos de Manaus no anel 1, Vitória no anel 4, Pecém e Vila do Conde no anel 6, locais especialmente modelados para que não houvesse qualquer cancelamento de escala.

Verificou-se, ao final da simulação, que todos os 12 navios cumpriram todas as 8760 horas seguindo, com rigor, os dados estabelecidos na proforma, ou seja, a simulação do sistema completo com dados determinísticos promoveu uma plena aderência do modelo computacional às proformas reais, uma vez que todos os navios igualaram os tempos de saídas e chegadas, tempos de operação e volumes movimentados àqueles do plano original, ao longo de toda a simulação.

A tabela 8 apresenta os resultados simulados para a variável Tempo Total de Operação, que é resultado da combinação de todas as demais variáveis envolvidas (volume, produtividade, guindastes utilizados e espera não-operacional). Verifica-se que os tempos obtidos através da simulação é rigorosamente idêntico aos valores da proforma determinística, em todas as $n$ observações, validando o modelamento matemático e lógicas utilizadas. 
Tabela 8 - Verificação dos tempos de operação (h)

\begin{tabular}{|c|c|c|c|c|c|c|c|}
\hline Anel & Porto & 1 & 2 & $\ldots$ & $\mathrm{n}-1$ & $\mathbf{n}$ & Proforma \\
\hline \multirow{12}{*}{ Anel 1} & Itapoa & 18,0 & 18,0 & $\ldots$ & 18,0 & 18,0 & 18,0 \\
\hline & Santos N & 18,0 & 18,0 & $\ldots$ & 18,0 & 18,0 & 18,0 \\
\hline & Sepetiba N & 20,0 & 20,0 & $\ldots$ & 20,0 & 20,0 & 20,0 \\
\hline & Salvador $\mathbf{N}$ & 16,0 & 16,0 & $\ldots$ & 16,0 & 16,0 & 16,0 \\
\hline & Suape N & 20,0 & 20,0 & $\ldots$ & 20,0 & 20,0 & 20,0 \\
\hline & Pecém N & 17,0 & 17,0 & $\ldots$ & 17,0 & 17,0 & 17,0 \\
\hline & Manaus N & 80,0 & 80,0 & $\ldots$ & 80,0 & 80,0 & 80,0 \\
\hline & Pecém S & 14,0 & 14,0 & $\ldots$ & 14,0 & 14,0 & 14,0 \\
\hline & Suape S & 15,0 & 15,0 & $\ldots$ & 15,0 & 15,0 & 15,0 \\
\hline & Salvador S & 18,0 & 18,0 & $\ldots$ & 18,0 & 18,0 & 18,0 \\
\hline & Sepetiba S & 19,0 & 19,0 & $\ldots$ & 19,0 & 19,0 & 19,0 \\
\hline & Santos S & 19,0 & 19,0 & $\ldots$ & 19,0 & 19,0 & 19,0 \\
\hline \multirow{8}{*}{ Anel 2} & Rio Grande & 18,0 & 18,0 & $\ldots$ & 18,0 & 18,0 & 18,0 \\
\hline & Imbituba & 16,0 & 16,0 & $\ldots$ & 16,0 & 16,0 & 16,0 \\
\hline & Santos N & 18,0 & 18,0 & $\ldots$ & 18,0 & 18,0 & 18,0 \\
\hline & Salvador & 18,0 & 18,0 & $\ldots$ & 18,0 & 18,0 & 18,0 \\
\hline & Suape & 22,0 & 22,0 & $\ldots$ & 22,0 & 22,0 & 22,0 \\
\hline & Pecém & 18,0 & 18,0 & $\ldots$ & 18,0 & 18,0 & 18,0 \\
\hline & Santos (BTP) & 10,0 & 10,0 & $\ldots$ & 10,0 & 10,0 & 10,0 \\
\hline & Santos (SBSA) & 12,0 & 12,0 & $\ldots$ & 12,0 & 12,0 & 12,0 \\
\hline \multirow{6}{*}{ Anel 3} & Buenos Aires & 18,0 & 18,0 & $\ldots$ & 18,0 & 18,0 & 18,0 \\
\hline & Zarate & 42,0 & 42,0 & $\ldots$ & 42,0 & 42,0 & 42,0 \\
\hline & Rosario & 19,0 & 19,0 & $\ldots$ & 19,0 & 19,0 & 19,0 \\
\hline & Itapoa & 11,0 & 11,0 & $\ldots$ & 11,0 & 11,0 & 11,0 \\
\hline & Santos (SBSA) & 24,0 & 24,0 & $\ldots$ & 24,0 & 24,0 & 24,0 \\
\hline & Santos (BTP) & 8,0 & 8,0 & $\ldots$ & 8,0 & 8,0 & 8,0 \\
\hline \multirow{4}{*}{ Anel 4} & Santos (SBSA) & 14,5 & 14,5 & $\ldots$ & 14,5 & 14,5 & 14,5 \\
\hline & Santos (EMB) & 4,0 & 4,0 & $\ldots$ & 4,0 & 4,0 & 4,0 \\
\hline & Rio de Janeiro & 9,0 & 9,0 & $\ldots$ & 9,0 & 9,0 & 9,0 \\
\hline & Vitória & 31,0 & 31,0 & $\ldots$ & 31,0 & 31,0 & 31,0 \\
\hline \multirow{3}{*}{ Anel 5} & Pecém & 12,0 & 12,0 & $\ldots$ & 12,0 & 12,0 & 12,0 \\
\hline & Vila do Conde & 30,0 & 30,0 & $\ldots$ & 30,0 & 30,0 & 30,0 \\
\hline & São Luiz & 8,0 & 8,0 & $\ldots$ & 8,0 & 8,0 & 8,0 \\
\hline
\end{tabular}

Fonte: Autor

Um segundo aspecto de importante validação está relacionado às omissões por atraso ou antecipação de escala, assim como chegadas fora de janela nos portos de Manaus, Pecém (Anel 6), Vitória e Vila do Conde, nos quais considera-se que não haverá omissões por serem os portos-chave de seus respectivos anéis. Conforme apresentado na tabela 9 , ao longo de toda a simulação não foram computadas omissões ou chegadas fora de janela, como esperado para o modelo alimentado por dados determinísticos. 
Tabela 9 - Soma de quantidade de omissões

\begin{tabular}{|c|ccc|}
\cline { 3 - 4 } \multicolumn{1}{c}{} & \multicolumn{2}{c|}{ Tempo de Simulação (h) } \\
\hline Tipo & Porto & $\mathbf{0}$ & $\mathbf{8 7 6 0}$ \\
\hline \multirow{3}{*}{ Fora de } & Manaus & 0 & 0 \\
& Pecém & 0 & 0 \\
& Vitória & 0 & 0 \\
& Vila do Conde & 0 & 0 \\
\hline \multirow{5}{*}{ Omissão } & Santos (BTP) & 0 & 0 \\
& Buenos Aires & 0 & 0 \\
& Santos (EMB) & 0 & 0 \\
& Imbituba & 0 & 0 \\
& Itapoa & 0 & 0 \\
& Pecém & 0 & 0 \\
& Rio Grande & 0 & 0 \\
& Rio de Janeiro & 0 & 0 \\
& Rosario & 0 & 0 \\
& São Luiz & 0 & 0 \\
& Sepetiba & 0 & 0 \\
& Salvador & 0 & 0 \\
& Santos (SBSA) & 0 & 0 \\
& Suape & 0 & 0 \\
& Zarate & 0 & 0 \\
\hline
\end{tabular}

Fonte: Autor

O terceiro aspecto validado foi a distância navegada por cada navio e seus respectivos consumos. Como todos os trechos são navegados na mesma velocidade e as operações portuárias acontecem dentro do mesmo espaço de tempo, não eram esperadas quaisquer variações de consumo entre viagens do mesmo navio, ou até mesmo da mesma classe de navios. De maneira análoga à validação dos tempos totais de operação e retirando a última viagem simulada, ainda incompleta, os dados apresentados na tabela 10 legitimam o cálculo de consumo do modelo e confirmam a expectativa supracitada. 
Tabela 10 - Verificação de consumos e distâncias

\begin{tabular}{|c|c|c|c|c|c|c|c|}
\hline Variável & Anel & Navio & 1 & 2 & $\ldots$ & $n$ & Proforma \\
\hline \multirow{12}{*}{$\begin{array}{c}\text { Consumo } \\
\text { (ton/h) }\end{array}$} & \multirow{5}{*}{ Anel 1} & AMVES & 932 & 932 & $\ldots$ & 932 & 932 \\
\hline & & FERMA & 932 & 932 & $\ldots$ & 932 & 932 \\
\hline & & PECAB & 932 & 932 & $\ldots$ & 932 & 932 \\
\hline & & SECAB & 932 & 932 & $\ldots$ & 932 & 932 \\
\hline & & SOLIS & 756 & 756 & $\ldots$ & 756 & 756 \\
\hline & \multirow{3}{*}{ Anel 2} & BARDI & 698 & 698 & $\ldots$ & 698 & 698 \\
\hline & & MOSAR & 946 & 946 & $\ldots$ & 946 & 946 \\
\hline & & VIPIN & 698 & 698 & $\ldots$ & 698 & 698 \\
\hline & \multirow{2}{*}{ Anel 3} & ALMAN & 243 & 243 & $\ldots$ & 243 & 243 \\
\hline & & NORDA & 221 & 221 & $\ldots$ & 221 & 221 \\
\hline & Anel 4 & LOGPA & & & $\ldots$ & & 0 \\
\hline & Anel 6 & ALLEB & 135 & 135 & $\ldots$ & 135 & 135 \\
\hline \multirow{12}{*}{$\begin{array}{l}\text { Distância } \\
\text { (mn) }\end{array}$} & \multirow{5}{*}{ Anel 1} & AMVES & 6.664 & 6.664 & $\ldots$ & 6.664 & 6.664 \\
\hline & & FERMA & 6.664 & 6.664 & $\ldots$ & 6.664 & 6.664 \\
\hline & & PECAB & 6.664 & 6.664 & $\ldots$ & 6.664 & 6.664 \\
\hline & & SECAB & 6.664 & 6.664 & $\ldots$ & 6.664 & 6.664 \\
\hline & & SOLIS & 6.664 & 6.664 & $\ldots$ & 6.664 & 6.664 \\
\hline & \multirow{3}{*}{ Anel 2} & BARDI & 4.671 & 4.671 & $\ldots$ & 4.671 & 4.671 \\
\hline & & MOSAR & 4.671 & 4.671 & $\ldots$ & 4.671 & 4.671 \\
\hline & & VIPIN & 4.671 & 4.671 & $\ldots$ & 4.671 & 4.671 \\
\hline & \multirow{2}{*}{ Anel 3} & ALMAN & 2.447 & 2.447 & $\ldots$ & 2.447 & 2.447 \\
\hline & & NORDA & 2.447 & 2.447 & $\ldots$ & 2.447 & 2.447 \\
\hline & Anel 4 & LOGPA & 1.031 & 1.031 & $\ldots$ & 1.031 & 1.031 \\
\hline & Anel 6 & ALLEB & 1.450 & 1.450 & $\ldots$ & 1.450 & 1.450 \\
\hline
\end{tabular}

Fonte: Autor

A última validação teve como objetivo verificar os tempos totais de viagem de cada navio em cada anel, pois estes também devem ser os mesmos ao longo de toda a simulação, já que não há nenhuma variabilidade nos dados provenientes da proforma. A tabela 11 apresenta o tempo total de viagem das $n$ viagens simuladas e verifica-se que, de fato, todas as viagens de cada navio apresentaram rigorosamente a mesma duração, certificando o modelo como totalmente aderente aos processos envolvidos no serviço. A diferença observada na primeira viagem é referente ao tempo adicional em que as embarcações aguardam atracação devido à chegada no modelo, parâmetro no qual foi considerado certo tempo adicional, garantindo o início da operação regular no primeiro porto dentro de sua janela. 
Tabela 11 - Verificação de duração das viagens

\begin{tabular}{|c|c|c|c|c|c|c|c|c|}
\hline Anel & Navio & 1 & 2 & 3 & 4 & $\ldots$ & $\mathrm{n}$ & Proforma \\
\hline \multirow{5}{*}{ Anel 1} & AMVES & 851 & 840 & 840 & 840 & ב... & 840 & 840,0 \\
\hline & FERMA & 851 & 840 & 840 & 840 & $\ldots$ & 840 & 840,0 \\
\hline & PECAB & 851 & 840 & 840 & 840 & $\ldots$ & 840 & 840,0 \\
\hline & SECAB & 851 & 840 & 840 & 840 & $\ldots$ & 840 & 840,0 \\
\hline & SOLIS & 851 & 840 & 840 & 840 & $\ldots$ & 840 & 840,0 \\
\hline \multirow{3}{*}{ Anel 2} & BARDI & 517 & 504 & 504 & 504 & $\ldots$ & 504 & 504,0 \\
\hline & MOSAR & 517 & 504 & 504 & 504 & $\ldots$ & 504 & 504,0 \\
\hline & VIPIN & 517 & 504 & 504 & 504 & $\ldots$ & 504 & 504,0 \\
\hline \multirow{2}{*}{ Anel 3} & ALMAN & 335 & 336 & 336 & 336 & $\ldots$ & 336 & 336,0 \\
\hline & NORDA & 335 & 336 & 336 & 336 & $\ldots$ & 336 & 336,0 \\
\hline Anel 4 & LOGPA & 163 & 168 & 168 & 168 & $\ldots$ & 168 & 168,0 \\
\hline Anel 6 & ALLEB & 181 & 168 & 168 & 168 & $\ldots$ & 168 & 168,0 \\
\hline
\end{tabular}

Fonte: Autor

Com base nos dados acima mencionados, ratifica-se a validade do modelo e das lógicas estabelecidas como representação do serviço real e outorga-se o prosseguimento à segunda etapa da simulação: a adoção dos dados estocásticos no modelo e ressimulação, agora com influência das diversas aleatoriedades presentes no sistema real.

\subsection{SEGUNDA SIMULAÇÃO E VALIDAÇÃO DOS PARÂMETROS}

Para a segunda simulação, os parâmetros e variáveis de entrada foram atualizados com a inclusão das expressões estatísticas levantadas para cada etapa da operação. Então, um novo processamento foi realizado e seus dados coletados para análise e aferição dos parâmetros. Devido à natureza estatística dos novos dados inseridos no modelo, faz-se necessário, inicialmente, verificar se os valores aleatoriamente gerados pelo sistema durante o processo computacional são aderentes aos dados reais coletados, fato decisivo para o sucesso da simulação, uma vez que dados pouco aderentes levarão a conclusões inconsistentes, ainda que o modelo seja aderente à realidade.

Como validação primária, compararam-se os parâmetros obtidos durante a simulação para as variáveis PreOp, PosOp, Prod./Guindaste, Guindastes e Volume com os dados reais coletados, base para o levantamento estatístico realizado. Primeiramente, foram verificadas as médias das $\mathrm{n}$ medições para cada escala de cada anel e comparadas com as médias das leituras 
reais. A tabela 12 apresenta os resultados desta comparação entre os parâmetros simulados versus os dados reais coletados, granularizado por porto e direção

Tabela 12 - Validação dos parâmetros de entrada

\begin{tabular}{|c|c|c|c|c|c|c|c|c|c|c|c|c|c|c|c|c|c|}
\hline \multirow[b]{2}{*}{ Anel } & \multirow[b]{2}{*}{ Direção } & \multirow[b]{2}{*}{ Porto } & \multicolumn{3}{|c|}{ Espera PreOp (h) } & \multicolumn{3}{|c|}{ Espera PosOp (h) } & \multicolumn{3}{|c|}{ Produtividade (Mov./h) } & \multicolumn{3}{|c|}{ Guindastes (Quantidade) } & \multicolumn{3}{|c|}{ Volume (Mov./escala) } \\
\hline & & & Simul & Real & Delta & Simul & Real & Delta & Simul & Real & Delta & Simul & Real & Delta & Simul & Real & Delta \\
\hline Anel 1 & $N$ & Itapoa & 1,65 & 2,00 & 0,35 & 2,28 & 2,61 & 0,33 & 28,05 & 27,37 & $-0,68$ & 2,99 & 3,06 & 0,07 & 891 & 872 & -19 \\
\hline Anel 1 & $\mathrm{~N}$ & Santos & 1,61 & 2,13 & 0,52 & 3,28 & 2,74 & $-0,54$ & 24,96 & 24,87 & $-0,09$ & 2,56 & 2,52 & $-0,04$ & 572 & 561 & -11 \\
\hline Anel 1 & $\mathrm{~N}$ & Sepetiba & 3,48 & 4,65 & 1,17 & 1,84 & 1,85 & 0,01 & 25,03 & 25,14 & 0,11 & 2,57 & 2,55 & $-0,02$ & 558 & 625 & 67 \\
\hline Anel 1 & $\mathrm{~N}$ & Salvador & 4,42 & 4,74 & 0,32 & 1,42 & 1,47 & 0,05 & 25,06 & 24,87 & $-0,19$ & 2,51 & 2,53 & 0,02 & 291 & 298 & 7 \\
\hline Anel 1 & $\mathrm{~N}$ & Suape & 1,64 & 1,55 & $-0,00$ & 1,60 & 1,61 & 0,01 & 25,14 & 24,01 & $-1,13$ & 2,48 & 2,44 & $-0,04$ & 681 & 675 & -6 \\
\hline Anel 1 & $\mathrm{~N}$ & Pecem & 1,81 & 1,85 & 0,04 & 1,80 & 1,60 & $-0,20$ & 32,10 & 31,99 & $-0,11$ & 1,95 & 1,93 & $-0,02$ & 731 & 733 & 2 \\
\hline Anel 1 & $\mathrm{~s}$ & Manaus & 1,64 & 1,91 & 0,27 & 3,50 & 4,23 & 0,73 & 13,73 & 13,82 & 0,09 & 2,82 & 2,82 & 0,00 & 2309 & 2275 & -34 \\
\hline Anel 1 & $\mathrm{~s}$ & Pecem & 1,87 & 1,87 & 0,00 & 1,80 & 1,48 & $-0,32$ & 33,56 & 33,50 & $-0,06$ & 1,82 & 1,84 & 0,02 & 355 & 359 & 4 \\
\hline Anel 1 & $\mathrm{~s}$ & Suape & 1,31 & 1,60 & 0,29 & 1,32 & 1,62 & 0,30 & 27,19 & 25,53 & $-1,66$ & 2,40 & 2,36 & $-0,04$ & 447 & 475 & 28 \\
\hline Anel 1 & $\mathrm{~s}$ & Salvador & 2,44 & 1,50 & $-0,94$ & 1,53 & 1,52 & $-0,01$ & 23,71 & 24,29 & 0,58 & 2,33 & 2,51 & 0,18 & 517 & 486 & -31 \\
\hline Anel 1 & S & Sepetiba & 4,09 & 2,41 & $-1,68$ & 1,59 & 1,92 & 0,33 & 25,03 & 27,17 & 2,14 & 2,20 & 2,48 & 0,28 & 512 & 559 & 47 \\
\hline Anel 1 & s & Santos & 1,50 & 1,31 & $-0,19$ & 2,89 & 3,13 & 0,24 & 29,12 & 29,97 & 0,85 & 3,05 & 3,40 & 0,35 & 1232 & 1200 & -32 \\
\hline
\end{tabular}

Fonte: Autor

A comparação completa entre os dados simulados e reais mostra que as médias dos valores obtidos para cada escala ao longo das horas simuladas pouco divergem das médias dos dados reais para os mesmos portos e escalas, comprovando boa aderência dos modelos estatísticos utilizados. Dada a alta variabilidade inerente às operações portuárias, considera-se que os desvios encontrados, mesmo os mais expressivos, estão em patamares aceitáveis e que refletem a realidade das operações.

Como o tempo de operação pura depende de três das cinco variáveis aqui demonstradas, foram calculados os tempos médios de operação real e simulado, pois, embora os dados individuais apresentem boa aderência, nada se pode afirmar sobre o tempo total, pois o acúmulo de diferenças poderia levar a distorções significativas. O histograma da figura 19 mostra que os tempos de operação pura também apresentam variações pequenas, com a grande maioria dos portos apresentando variações menores que uma hora, para mais ou para menos, sendo apenas dois casos acima de 2 horas, ainda assim ultrapassando este limite por menos de 10 minutos. 
Figura 19 - Histograma da variação do tempo de operação (h)

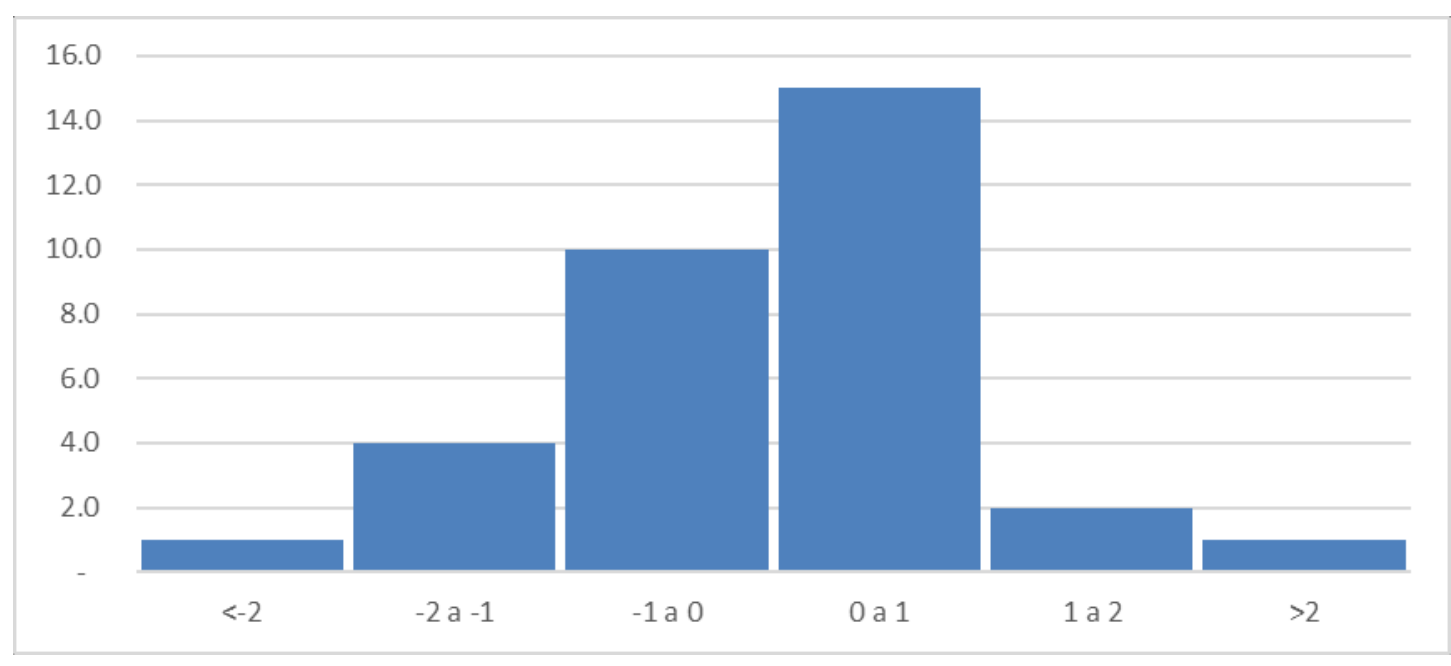

Fonte: Autor

Considera-se, ainda, que tais variações são não somente aceitáveis, mas importantes para o modelo, já que este simulará situações novas, com maior propensão a disrupções operacionais, cuja identificação é o produto principal deste estudo. A comparação completa pode ser visualizada na tabela 13 . 
Tabela 13 - Resultado da validação dos parâmetros

\begin{tabular}{|c|c|c|c|c|c|c|c|c|}
\hline Anel & Direção & Porto & PreOp & PosOp & Prod. & Guind. & Volume & TOp \\
\hline Anel 1 & $\mathrm{~N}$ & Itapoa & 0,35 & 0,33 & $-0,68$ & 0,07 & $-19,74$ & $-0,23$ \\
\hline Anel 1 & $\mathrm{~N}$ & Santos & 0,53 & $-0,54$ & $-0,09$ & $-0,04$ & $-10,19$ & 0,01 \\
\hline Anel 1 & $\mathrm{~N}$ & Sepetiba & 1,17 & 0,01 & 0,10 & $-0,02$ & 66,3 & 1,08 \\
\hline Anel 1 & $\mathrm{~N}$ & Salvador & 0,33 & 0,05 & $-0,19$ & 0,02 & 6,45 & 0,09 \\
\hline Anel 1 & $\mathrm{~N}$ & Suape & $-0,10$ & 0,01 & $-1,13$ & $-0,04$ & $-6,22$ & 0,60 \\
\hline Anel 1 & $\mathrm{~N}$ & Pecem & 0,03 & $-0,20$ & $-0,10$ & $-0,02$ & 2,16 & 0,18 \\
\hline Anel 1 & $S$ & Manaus & 0,26 & 0,73 & 0,10 & 0,01 & $-34,36$ & $-1,43$ \\
\hline Anel 1 & $S$ & Pecem & $-0,01$ & $-0,32$ & $-0,07$ & 0,02 & 4,51 & 0,02 \\
\hline Anel 1 & $S$ & Suape & 0,30 & 0,30 & $-1,66$ & $-0,04$ & 28,25 & 1,05 \\
\hline Anel 1 & $S$ & Salvador & $-0,94$ & $-0,02$ & 0,59 & 0,19 & $-31,22$ & $-1,42$ \\
\hline Anel 1 & $S$ & Sepetiba & $-1,68$ & 0,32 & 2,14 & 0,27 & 47,67 & $-0,96$ \\
\hline Anel 1 & $S$ & Santos & $-0,20$ & 0,24 & 0,85 & 0,34 & $-32,17$ & $-2,07$ \\
\hline Anel 2 & $\mathrm{~N}$ & Rio Grande & 0,12 & $-0,01$ & 0,12 & 0,05 & 8,53 & $-0,10$ \\
\hline Anel 2 & $\mathrm{~N}$ & Imbituba & $-0,28$ & 0,10 & 0,11 & $-0,01$ & $-3,81$ & $-0,01$ \\
\hline Anel 2 & $\mathrm{~N}$ & Santos & 0,05 & 0,32 & $-0,76$ & $-0,02$ & 0,30 & 0,34 \\
\hline Anel 2 & $S$ & Salvador & $-0,03$ & 0,01 & $-0,35$ & $-0,03$ & 40,29 & 0,74 \\
\hline Anel 2 & $S$ & Suape & $-0,09$ & $-0,12$ & 0,64 & 0,06 & $-36,65$ & $-1,33$ \\
\hline Anel 2 & $S$ & Pecem & $-0,18$ & $-0,11$ & $-0,17$ & $-0,04$ & $-34,77$ & $-0,02$ \\
\hline Anel 2 & $S$ & Santos BTP & $-0,14$ & 0,35 & $-0,56$ & 0,00 & $-12,36$ & $-0,08$ \\
\hline Anel 2 & $S$ & Santos & $-0,93$ & $-0,35$ & 0,51 & 0,00 & 44,62 & 0,85 \\
\hline Anel 3 & $\mathrm{~N}$ & Buenos Aires & 0,00 & 0,07 & $-0,17$ & 0,00 & $-3,45$ & 0,15 \\
\hline Anel 3 & $\mathrm{~N}$ & Zarate & 0,12 & $-0,12$ & 0,37 & 0,00 & 14,32 & 0,18 \\
\hline Anel 3 & $\mathrm{~N}$ & Rosario & 0,43 & $-0,03$ & 0,03 & 0,00 & $-2,23$ & $-0,12$ \\
\hline Anel 3 & $S$ & Itapoa & $-0,34$ & $-0,11$ & $-0,58$ & 0,00 & $-14,64$ & 0,16 \\
\hline Anel 3 & $\mathrm{~S}$ & Santos BTP & 0,00 & 0,97 & 0,17 & 0,00 & 2,99 & $-1,01$ \\
\hline Anel 3 & $S$ & Santos & $-0,05$ & $-0,13$ & 0,55 & 0,00 & $-2,72$ & 0,27 \\
\hline Anel 4 & $\mathrm{~N}$ & Santos & $-0,15$ & $-0,04$ & 0,61 & 0,00 & 62,94 & 0,74 \\
\hline Anel 4 & $\mathrm{~N}$ & Santos Embraport & $-1,04$ & $-0,11$ & $-0,56$ & 0,00 & 30,41 & 0,23 \\
\hline Anel 4 & $\mathrm{~N}$ & Rio de Janeiro & $-0,07$ & $-0,23$ & 1,61 & 0,00 & 0,98 & $-0,36$ \\
\hline Anel 4 & $\mathrm{~S}$ & Vitoria & $-0,01$ & $-0,32$ & $-0,67$ & 0,00 & 5,28 & 2,13 \\
\hline Anel 6 & $\mathrm{~N}$ & Pecem & $-0,07$ & $-0,02$ & $-0,47$ & 0,00 & $-10,86$ & $-0,09$ \\
\hline Anel 6 & $S$ & Vila do Conde & $-1,41$ & 0,07 & $-0,02$ & 0,00 & 17,75 & 0,66 \\
\hline Anel 6 & $S$ & São Luiz & 0,15 & $-0,27$ & 0,25 & 0,00 & $-4,11$ & $-0,89$ \\
\hline \multicolumn{3}{|c|}{ Variação Máxima } & 1,17 & 0,97 & 2,14 & 0,34 & 66,30 & 2,13 \\
\hline \multicolumn{3}{|c|}{ Variação Mínima } & $-1,68$ & $-0,54$ & $-1,66$ & $-0,16$ & $-36,65$ & $-2,07$ \\
\hline
\end{tabular}

Fonte: Autor

A análise da média apenas não é inteiramente conclusiva para garantir a plausibilidade dos dados simulados, pois ela é pouca coisa alterada por pontos extremos, ao passo que a simulação acaba sendo seriamente afetada por valores exageradamente altos ou baixos fora da realidade, prejudicando a qualidade dos resultados obtidos.

Foi realizada, assim, para cada uma das variáveis, a análise compreensiva de todos os valores simulados, visando identificar valores fora da realidade. Esta análise mostra que as medições, embora tenham grande variabilidade, também apresentaram valores condizentes com a realidade. Para algumas variáveis, notam-se alguns valores bastante elevados e outros bastante 
baixos, que poderiam ser caracterizados como erro estatístico. Porém, em comparação com os dados reais, percebe-se que houve situações em que estas variáveis assumiram valores bastante divergentes da média. Desta forma, conclui-se, também, que os valores individuais utilizados durante a simulação estão dentro da conformidade e que casos com variações extremas também são oportunos ao simularem situações reais de problemas operacionais, aumentos repentinos de volume devido a demanda represada, entre outros.

\subsection{ANÁLISE DOS DADOS OBTIDOS}

Uma vez que tanto o modelo de simulação quanto os dados de entrada estejam validados, segue-se com a análise dos resultados obtidos através da simulação. Devido à grande complexidade do sistema de cabotagem aqui analisado, é interessante examinar cada anel individualmente.

\subsubsection{Anel 1}

No anel que conecta o Brasil ao porto de Manaus, o maior dos 5 anéis, o primeiro aspecto que chama a atenção é a quantidade de omissões ocorridas nas escalas da direção sul, após a escala de Manaus. Conforme apresentado na tabela 14, todas as escalas da direção sul deste anel apresentaram mais de 40 omissões, somando os cortes de todos os 5 navios, exceto pelo porto de Itapoa, que teve 36 omissões gerais, um número muito elevado.

Na direção norte, por sua vez, poucas omissões foram calculadas, com 9 para Santos, 8 em Suape, 6 em Sepetiba e apenas 1 nos portos de Pecém, Salvador e Manaus, sendo que neste último não há omissão propriamente dita, mas sim uma indicação de chegada fora de janela. Estes números, para um ano inteiro de serviço, apresentam-se muito consistentes e dentro da

realidade. É importante notar que estas omissões são decorrência da variabilidade das condições operacionais, que acarretam atrasos nas operações e, consequentemente, disrupções na programação. 
Tabela 14 - Omissões no anel 1

\begin{tabular}{cc|ccccc|c} 
Porto & Direção & SECAB & PECAB & FERMA & AMVES & SOLIS & Total \\
\hline Pecém & $\mathrm{S}$ & 11 & 7 & 10 & 9 & 9 & $\mathbf{4 6}$ \\
Sepetiba & $\mathrm{S}$ & 11 & 8 & 9 & 8 & 9 & $\mathbf{4 5}$ \\
Suape & $\mathrm{S}$ & 11 & 7 & 9 & 8 & 9 & $\mathbf{4 4}$ \\
Santos & $\mathrm{S}$ & 11 & 6 & 9 & 9 & 9 & $\mathbf{4 4}$ \\
Salvador & $\mathrm{S}$ & 11 & 7 & 9 & 8 & 9 & $\mathbf{4 4}$ \\
Itapoa & $\mathrm{S} / \mathrm{N}$ & 10 & 5 & 6 & 6 & 9 & $\mathbf{3 6}$ \\
Santos & $\mathrm{N}$ & 1 & 3 & 2 & 1 & 2 & $\mathbf{9}$ \\
Suape & $\mathrm{N}$ & 2 & 2 & 2 & & 2 & $\mathbf{8}$ \\
Sepetiba & $\mathrm{N}$ & 2 & 1 & 1 & 2 & & $\mathbf{6}$ \\
Pecém & $\mathrm{N}$ & 1 & & & & & $\mathbf{1}$ \\
Salvador & $\mathrm{N}$ & & 1 & & & & $\mathbf{1}$ \\
Manaus & $\mathrm{N} / \mathrm{S}$ & & 1 & & & & $\mathbf{1}$
\end{tabular}

Fonte: Autor

Para entender os motivos que levaram a esta elevada quantidade de omissões nas viagens de retorno, faz-se necessário entender, em primeiro lugar, o momento em que estes navios chegaram ao porto, para verificar se houve antecipação ou atraso na saída do porto anterior, uma vez que os tempos de navegação foram mantidos constantes ao longo da simulação.

A primeira omissão das escalas da direção sul ocorreu logo na primeira viagem do primeiro navio. Após a operação de Manaus, nenhuma escala havia sido cancelada, até que, ao chegar em Pecém, houve a omissão. Uma investigação mais aproundada mostrou que o navio adentrou a área portuária de Pecém na hora 692,3 da simulação, ou seja, 11,7 horas antes do período de 36 horas em que o navio aguarda a abertura de sua janela para proceder à operação.

Como a operação de Manaus foi bem sucedida, entende-se que houve uma antecipação da saída do navio, proveniente a um volume de cargas menor, ou de produtividade maior. Neste caso, analisou-se a escala de Manaus, e constatou-se que esta seguiu dentro dos padrões. Conforme mostram as tabelas 15 e 16, a simulação apontou a chegada do navio ao porto de Manaus dentro do período pré-atracação, seguindo ao terminal no exato momento da abertura da janela. Os dados de volumes e produtividades condizem com os valores reais, e o mesmo ocorre com o tempo de espera. Ao comparar com a proforma, no entanto, verifica-se que esta última adiciona 14 horas ao tempo médio de operação, que não condiz com a realidade. Assim, os navios acabam por sistematicamente sair antes do momento estipulado na proforma, prejudicando as demais escalas. 
Tabela 15 - Eventos da escala de Manaus

\begin{tabular}{ll} 
Tempo (h) & Evento \\
\hline 474,00 & Início da Pré-Janela \\
498,88 & Chegada do navio à barra \\
509,00 & Abertura da Janela \\
509,00 & Início da manobra de atracação \\
510,00 & Chegada do navio ao terminal \\
511,47 & Início das operações \\
516,00 & Fechamento da Janela \\
572,27 & Fim das operações \\
578,14 & Início da manobra de desatracação \\
579,14 & Chegada do navio à barra e partida
\end{tabular}

Fonte: Autor

Tabela 16 - Comparação das variáveis em Manaus

\begin{tabular}{|c|c|c|c|}
\hline \multicolumn{1}{|c}{ Dados de Entrada } & 60,0 & 69,2 & Palor Simul. \\
\hline Volume Hatch Cover (Mov.) & $2.172,0$ & $2.270,7$ & $2.178,0$ \\
\hline Volume Contêineres (Mov.) & 3,0 & 2,8 & 3,0 \\
\hline Guindastes Utilizados (Quantidade) & 12,4 & 13,8 & 11,0 \\
\hline Produtividade Média (Mov./h) & 60,8 & 60,0 & 66,0 \\
\hline Tempo de Operação (h) & 1,5 & 1,9 & 14,0 \\
\hline Espera Pré-Operação (h) & 5,9 & 4,2 & 80,0 \\
\hline Espera Pós-Operação (h) & 68,1 & 66,1 & \\
\hline Tempo Total Atracado (h) & & & \\
\hline
\end{tabular}

Fonte: Autor

Além disto, no porto de Pecém existe um segundo buffer de 34 horas na proforma, que amplia este tempo parado e contribui significativamete para a chegada extra-antecedente ao porto de Pecém, incorrendo no cancelamento da escala.

Verifica-se, portanto, um exagerado zêlo na confecção da proforma, por colocar excessos de buffer nos portos de Manaus e na chegada a Pecém, prejudicando o planejamento geral, além de prolongarem o tempo ocioso das embarcações, incorrendo em custos extras não recuperáveis. Um segundo agravante, observado na simulação, é que, devido às sucessivas omissões na sua descida ao sul do país, este navio conseguiu apenas voltar ao seu planejamento no porto de Santos, realizando uma descida muito mais acelerada do que de costume. Devido ao célere deslocamento, houve um segundo efeito negativo: a sobreposição de dois navios do mesmo serviço e direção. Estes efeitos são nocivos ao sistema, pois prejudicam a disponibilidade de capacidade semanal aos clientes da empresa, ao mesmo tempo que criam um paralelismo desnecessário, com consequente ociosidade devido ao excesso de capacidade decorrentes de duas embarcações simultâneas. 
Para solucionar este percalço, foi realizada uma segunda simulação, na qual a velocidade de navegação entre os portos de Manaus e Pecém foi diminuida em 2 nós. Desta forma, o trecho de 1413 milhas náuticas que anteriormente era percorrido em 112,1 horas, passou a ser navegado em 134,6 horas. Esta alteração trouxe um significativo impacto nas escalas da direção sul e na manutenção da regularidade do planejamento deste serviço, com a redução significativa do número de cancelamentos, como mostra a tabela 17.

Tabela 17 - Omissões no anel 1 - atualização

\begin{tabular}{cc|c} 
Porto & Direção & Total \\
\hline Pecém & $\mathrm{S}$ & $\mathbf{1 3}$ \\
Sepetiba & $\mathrm{S}$ & $\mathbf{1 3}$ \\
Suape & $\mathrm{S}$ & $\mathbf{2 6}$ \\
Santos & $\mathrm{S}$ & $\mathbf{1 2}$ \\
Salvador & $\mathrm{S}$ & $\mathbf{1 4}$ \\
Itapoa & $\mathrm{S} / \mathrm{N}$ & $\mathbf{1 5}$ \\
Santos & $\mathrm{N}$ & $\mathbf{7}$ \\
Suape & $\mathrm{N}$ & $\mathbf{4}$ \\
Sepetiba & $\mathrm{N}$ & $\mathbf{3}$ \\
Pecém & $\mathrm{N}$ & $\mathbf{2}$ \\
Salvador & $\mathrm{N}$ & $\mathbf{2}$ \\
Manaus & $\mathrm{N} / \mathrm{S}$ & $\mathbf{0}$
\end{tabular}

Fonte: Autor

Um segundo aspecto importante a se levar em consideração é que, com a redução da velocidade de navegação houve também uma redução do consumo total da maioria dos navios, como mostra a tabela 18 .

Tabela 18 - Redução de consumo (ton) devido à menor velocidade

\begin{tabular}{lccc} 
Navio & Cons. Simul. 1 & Cons. Simul. 2 & Delta \% \\
\hline AMVES & 8.948 & 8.709 & $-2,7 \%$ \\
\hline FERMA & 8.937 & 8.697 & $-2,7 \%$ \\
\hline PECAB & 8.986 & 8.790 & $-2,2 \%$ \\
\hline SECAB & 8.904 & 8.690 & $-2,4 \%$ \\
\hline SOLIS & 6.400 & 6.408 & $0,1 \%$ \\
\hline Total & 42.175 & 41.295 & $-2,1 \%$
\end{tabular}

Fonte: Autor 
Por último, vale o destaque para o consumo do navio SOLIS, aproximadamente $30 \%$ abaixo dos outros 4. Embora todas estas embarcações tenham porte muito similar, os 4 primeiros apresentados na tabela são pertencentes a uma classe (projeto) mais antigo, com quase 10 anos de uso, enquanto este último é mais novo, com tecnologia bastante mais avançada empregada em seu propulsor, resultado nesta significativa redução de consumo.

Em termos financeiros, considerando-se um preço médio de US\$350 por tonelada métrica de combustível, média praticada pela Petrobrás para abastecimento em Santos durante o mês de Novembro de 2020, a redução de velocidade leva a um impacto positivo de US\$300.000,00, aproximadamente. Já em relação ao navio SOLIS, a economia de combustível proporcionada pela tecnologia mais recente leva a um impacto positivo de aproximadamente US\$800.000,00 anuais, demonstrando a importância dos avanços tecnológicos na fabricação de propulsores mais eficientes.

\subsubsection{Anel 2}

$\mathrm{O}$ anel 2 apresentou regularidade e confiabilidade superiores ao anel 1, com um número total de omisões menor, muito embora a escala no terminal BTP em Santos tenha sofrido diversos cancelamentos, como apresentado na tabela 19.

Tabela 19 - Omissões no anel 2

\begin{tabular}{cc|ccc|c|} 
Porto & Direção & MOSAR & VIPIN & BARDI & Total \\
Santos BTP & S & 9 & 9 & 10 & $\mathbf{2 8}$ \\
Rio Grande & N & 3 & 3 & 4 & 10 \\
Santos SBSA & N & 3 & 1 & 4 & $\mathbf{8}$ \\
Santos SBSA & S & 3 & 2 & 2 & $\mathbf{7}$ \\
Suape & S & 1 & 2 & 1 & 4 \\
Salvador & S & 1 & 2 & & 3 \\
Imbituba & N & 1 & & 1 & $\mathbf{2}$ \\
Pecém & S & 2 & & & $\mathbf{2}$ \\
\hline Total & & $\mathbf{2 3}$ & $\mathbf{1 9}$ & $\mathbf{2 2}$ & $\mathbf{6 4}$
\end{tabular}

Fonte: Autor

A primera providência é identificar se estes atrasos são sistemáticos, como acontecia com o Anel 1, ou se são pontuais e, portanto, devidos à variações das condições operacionais dos portos anteriores, assim como entender se houve antecipação excessiva da chegada da embarcação, ou atraso. Verifica-se que, no caso do Anel 2, as omissões não são sistemáticas, 
ou seja, são derivadas de oscilação das variáveis operacionais dos portos anteriores. Assim, coletaram-se os dados das escalas no porto de Pecém, logo anteriores àquelas omitidas no terminal BTP em Santos. As tabelas 20 e 21 apresentam um exemplo destes dados para a primeira viagem do navio MOSAR em que houve cancelamento no porto BTP.

Tabela 20 - Eventos das escalas Pecém e Santos

\begin{tabular}{|c|c|c|c|}
\hline Viagem & Tempo (h) & Porto & Evento \\
\hline MOSAR 1 & $1.895,00$ & Pecém & Início da Pré-Janela \\
\hline MOSAR 1 & $1.928,52$ & Pecém & Chegada do navio à barra \\
\hline MOSAR 1 & $1.930,00$ & Pecém & Abertura da Janela \\
\hline MOSAR 1 & $1.930,00$ & Pecém & Início da manobra de atracação \\
\hline MOSAR 1 & $1.931,00$ & Pecém & Chegada do navio ao terminal \\
\hline MOSAR 1 & $1.933,76$ & Pecém & Início das operações \\
\hline MOSAR 1 & $1.937,00$ & Pecém & Fechamento da Janela \\
\hline MOSAR 1 & $1.958,55$ & Pecém & Fim das operações \\
\hline MOSAR 1 & $1.960,48$ & Pecém & Início da manobra de desatracação \\
\hline MOSAR 1 & $1.961,48$ & Pecém & Chegada do navio à barra e partida \\
\hline MOSAR 1 & $2.052,00$ & Santos & Início da Pré-Janela (BTP) \\
\hline MOSAR 1 & $2.066,00$ & Santos & Início da Pré-Janela (SBSA) \\
\hline MOSAR 1 & $2.087,00$ & Santos & Abertura da Janela (BTP) \\
\hline MOSAR 1 & $2.094,00$ & Santos & Fechamento da Janela (BTP) \\
\hline MOSAR 1 & $2.098,48$ & Santos & Chegada do navio à barra \\
\hline MOSAR 1 & $2.101,00$ & Santos & Abertura da Janela (SBSA) \\
\hline MOSAR 1 & $1.930,00$ & Santos & Início da manobra de atracação (SBSA) \\
\hline
\end{tabular}

Fonte: Autor

Tabela 21 - Comparação das variáveis em Pecém

Viagem
\begin{tabular}{|c|c|c|c|c|}
\hline MOSAR 1 & Dados de Entrada & \multicolumn{2}{c|}{ Valor Simul. Média Hist. Proforma } \\
\hline MOSAR 1 & Volume Hatch Cover (Mov.) & 33,0 & 36,4 & - \\
\hline MOSAR 1 & Guindastes Utilizados (Quantidade) & 2,0 & 2,0 & 2,0 \\
\hline MOSAR 1 & Produtividade Média (Mov./h) & 27,7 & 32,1 & 29,0 \\
\hline MOSAR 1 & Tempo de Operação (h) & 24,8 & 21,1 & 18,0 \\
\hline MOSAR 1 & Espera Pré-Operação (h) & 2,8 & 2,1 & 1,0 \\
\hline MOSAR 1 & Espera Pós-Operação (h) & 1,9 & 1,5 & \\
\hline MOSAR 1 & Tempo Total Atracado (h) & 29,5 & 24,7 & 19,0 \\
\hline
\end{tabular}

Fonte: Autor

Analisando os dados supracitados, verifica-se que a embarcação chegou ao porto de Pecém dentro do prazo esperado e, no momento da abertura de sua janela de atracação, foi realizada a manobra de atracação. A operação no porto foi cerca de 5 horas mais longa do que a média histórica aponta, em decorrência de um pequeno aumento de volume (60 unidades) e 
uma pequena queda na produtividade média por guindaste, também dentro da normalidade. A proforma, no entanto, considera 10 horas a menos para operação neste porto, devido a uma estimativa baixa de volume (cerca de 350 unidades a menos). Devido a esta disparidade, a embarcação chegou pouco depois do fechamento da janela de atracação do porto Santos BTP, omitindo-o. Como ainda estava dentro do tempo de janela para a escala no porto de Santos SBSA, esta escala aconteceu normalmente.

Visualiza-se que, assim como no Anel 1, a proforma apresenta inconsistência em relação às médias históricas, acarretando em um planejamento muito antecipado das janelas nos terminais de Santos na direção sul, não deixando margens para eventuais delongas em operações anteriores.

Dentre as soluções possíveis, a mais rápida, e muito usada como alternativa no dia-adia devido a sua implementação imediata é o aumento de velocidade no trecho Pecém-Santos. Dado o fato de ser um trecho bastante longo, com 1.718 milhas náuticas, um pequeno incremento de velocidade, na ordem de 0,5 nó, já resgata estas pouco mais de 4 horas entre a chegada do navio e o fechamento da janela, diminuindo consideravelmente a quantidade de omissões deste porto, como mostra a compilação dos resultados da simulação com este incremento de velocidade apresentada na tabela 22.

Tabela 22 - Omissões no anel 2 - atualização

\begin{tabular}{cc|c} 
Porto & Direção & Total \\
Santos BTP & S & $\mathbf{7}$ \\
Rio Grande & N & $\mathbf{1 1}$ \\
Santos SBSA & N & $\mathbf{7}$ \\
Santos SBSA & S & $\mathbf{5}$ \\
Suape & S & $\mathbf{4}$ \\
Salvador & S & $\mathbf{2}$ \\
Imbituba & N & $\mathbf{3}$ \\
Pecém & S & $\mathbf{0}$ \\
\hline
\end{tabular}

Fonte: Autor

Nesta última simulação, além do incremento retromencionado, houve também o aumento de 0,9 nó na velocidade de navegação do trecho Santos-Rio Grande. Aqui, contudo, os resultados não foram expressivos, pois a causa principal para as disrupções de programação são algumas esperas prolongadas na saída do porto de Santos. Por se tratar de um trecho mais curto, é mais difícil descontar estes atrasos em tempo de navegação, pois fazem-se necessários incrementos consideráveis de velocidade, com significativo impacto no consumo. 
Embora seja uma solução viável, o aumento da velocidade causa um indesejável incremento no consumo, sendo, portanto, uma solução viável, porém pontual. Este aumento pode ser visualizado na tabela 23 .

Tabela 23 - Maior consumo decorrente da recuperação de programação

\begin{tabular}{lccc} 
Navio & Cons. Antigo & Cons. Novo & Delta \% \\
\hline BARDI & 11.063 & 11.317 & $2,3 \%$ \\
\hline MOSAR & 15.921 & 16.116 & $1,2 \%$ \\
\hline VIPIN & 11.073 & 11.297 & $2,0 \%$ \\
\hline Total & 38.058 & 38.730 & $1,8 \%$
\end{tabular}

Fonte: Autor

Utilizando o mesmo parâmetro de preço do anel anterior, o incremento de velocidade acarreta em um aumento de US\$250.000,00, aproximadamente. A decisão mais acertada é rever a proforma de maneira geral, incluindo maior buffer na saída do porto de Santos, minimizando o efeito destas prolongadas delongas decorrentes deste porto, e considerando médias de movimentação mais próximas à realidade para o porto de Pecém. Esta revisão é mais complexa, pois demanda reestruturação e renegociação das janelas com os terminais, mas garante no médio prazo uma confiabilidade maior ao sistema, sem incremento de consumo.

Destaca-se ainda que, da mesma maneira que no anel 1 o navio SOLIS contribui com um impacto muito positivo no custo total de Bunker, com a mesma capacidade, neste anel ocorre o efeito contrário com o navio MOSAR. Esta embarcação foi construída em 2005, quando era um dos maiores navios do mundo e uma classe de muito prestígio. Previsto e otimizado para travessias de longo curso, tem um motor grande e potente, feito para travessias com calados elevados e em velocidades altas. Na Cabotagem brasileira, contudo, é um navio pouco eficiente, pois seu desenho de casco favorece o ganho de calado mais acelerado do que os navios mais indicados para a navegação nacional, além de seu potente motor ter um consumo significativamente mais elevado.

Embora tenha efetivamente maior capacidade (cerca de 15\%) que seus companheiros do Anel 2, esse incremento acaba não sendo utilizado em sua totalidade, visto que operações em Liner Shipping visam, em primeiro lugar, a regularidade. Em contrapartida, seu consumo é muito mais elevado em relação aos outros dois, com um incremento no gasto anual de incríveis 
43\%. Em termos financeiros, seu maior consumo custa para o armador algo em torno de US\$ 1,7 milhão por ano.

A utilização desta embarcação só é justificada por falta de outra embarcação que atenda ao porte necessário para a Cabotagem, ou por uma necessidade pontual de se levar mais carga em um determinado trecho. Salvas estas condições, é mandatório revisar sua utilização e substituição por um navio mais adequado ao serviço.

\subsubsection{Anel 3}

Dentre os anéis deste serviço, este terceiro é dedicado ao atendimento da Grande Cabotagem, ou seja, o atendimento dos portos do Mercosul, portos conhecidos por suas instalações pouco modernizadas e baixos índices operacionais.

O resultado da simulação mostra, contudo, que a proforma foi elaborada de forma a contornar com bastante eficácia este cenário nos portos argentinos, porém não apresenta a mesma diligência para os portos brasileiros, mantendo tempos muito justos entre eles, contribuindo para um significativo incremento de omissões nos portos de Itapoa e Santos BTP, como mostra a tabela 24 .

Tabela 24 - Omissões no anel 3

\begin{tabular}{cc|cc|c} 
Porto & Direção & ALMAN & NORDA & Total \\
\hline Itapoa & S & 12 & 16 & $\mathbf{2 8}$ \\
Santos BTP & S & 7 & 6 & $\mathbf{1 3}$ \\
Rosario & N & 3 & 3 & $\mathbf{6}$ \\
Zarate & $\mathrm{N}$ & 0 & 3 & $\mathbf{3}$ \\
Buenos Aires & $\mathrm{N}$ & 1 & 2 & $\mathbf{3}$ \\
Santos SBSA & $\mathrm{S}$ & 1 & 1 & $\mathbf{2}$ \\
\hline
\end{tabular}

Fonte: Autor

Inicialmente, chama bastante a atenção a elevada quantidade de omissões no porto de Itapoa, com índice de um cancelamento a cada duas escalas. Seguindo a mesma análise realizada nos primeiros dois anéis, identificou-se que as embarcações sistematicamente chegam após a janela de atracação do porto de Itapoa, devido ao tempo de operação em Rosario ser mais longo do que previamente estabelecido na proforma. A tabela 25 mostra que o planejamento estratégico aponta um volume de movimentações 200 unidades menor do que a média histórica de movimentação neste porto, além de considerar metade do tempo de espera não-operacional. Com isso, a escala de Rosario conta com 8 horas a menos em seu planejamento 
do que seria requerido para a demanda deste porto, consequentemente antecipando a escala de Itapoa, diminuindo demasiadamente a confiabilidade da programação de chegada neste ancoradouro.

Tabela 25 - Comparação de variáveis em Rosario

\begin{tabular}{|c|c|c|c|c|c|c|c|c|c|c|}
\hline Dados de Entrada & Proforma & Média Hist. & ALMAN5 & ALMAN15 & ALMAN19 NORDA2 NORDA6 NORDA9 \\
\hline Volume Contêineres (Mov.) & 400 & 608 & 579 & 717 & 579 & 661 & 591 & 626 \\
\hline Guindastes Utilizados (Quantidade) & 2 & 2 & 2 & 2 & 2 & 2 & 2 & 2 \\
\hline Produtividade Média (Mov./h) & 12,0 & 14,0 & 14,1 & 15,4 & 13,0 & 12,8 & 12,7 & 11,4 \\
\hline Tempo de Operação (h) & 16,7 & 22,0 & 20,9 & 23,5 & 22,4 & 26,1 & 23,6 & 27,9 \\
\hline Espera não-operacional (h) & 2,3 & 5,0 & 5,2 & 4,6 & 5,6 & 3,2 & 10,2 & 3,2 \\
\hline Tempo Total Atracado (h) & 19,0 & 27,0 & 26,1 & 28,1 & 28,1 & 29,3 & 33,8 & 31,1 \\
\hline
\end{tabular}

Fonte: Autor

Ao aumentar a velocidade de navegação entre Rosario e Itapoa, no entanto, é parcialmente efetivo, pois resolve o problema de Itapoa, mas aumenta em Santos, cuja regularidade estava sendo beneficiada pela falta da escala no porto anterior. A atualização da quantidade de omissões é apresentada na tabela 26.

Tabela 26 - Omissões no anel 3 - atualização

\begin{tabular}{cc|c} 
Porto & Direção & Total \\
\hline Itapoa & S & $\mathbf{9}$ \\
Santos BTP & $\mathrm{S}$ & $\mathbf{1 4}$ \\
Rosario & $\mathrm{N}$ & $\mathbf{6}$ \\
Zarate & $\mathrm{N}$ & $\mathbf{3}$ \\
Buenos Aires & $\mathrm{N}$ & $\mathbf{2}$ \\
Santos SBSA & $\mathrm{S}$ & $\mathbf{1 2}$ \\
\hline
\end{tabular}

Fonte: Autor

Uma análise mais detalhada mostra que as escalas brasileiras exercem muita influência umas nas outras, de modo que poucas foram as viagens em que as três conexões foram efetivamente atendidas. Na maioria das viagens, contudo, houve cancelamento de um dos três portos, devido ao tempo insuficiente existente entre as escalas para que as operações aconteçam dentro do tempo esperado e o navio chegue a tempo da sua janela de atracação no porto seguinte. Assim, entende-se que o artifício de aumento de velocidade é não somente ruim financeira e ambientalmente falando, como também se mostra pouco efetivo, não resolvendo a problemática inicial deste anel. Desta forma, sugere-se que a proforma seja inteiramente revista, com históricos de volume e produtividade mais condizentes com os valores históricos e com 
renegociação de janelas de atracação garantindo o período adequado para a operação nos portos brasileiros.

De modo geral, as operações nos portos argentinos se mostraram sólidas e consistentes, ainda que longas devido aos baixos índices de produtividade portuária destes portos, como mostram as pequenas quantidades de omissões apontadas durante a simulação. No entanto, um fator preocupante é que o tempo de operação nos portos argentinos é muito maior do que o tempo de navegação entre eles, pois são geograficamente muito próximos. Desta forma, atrasos demasiadamente longos na operação destes portos tem grande potencial para criarem uma reação em cadeia causando uma sequência de chegadas significativamente antecipadas nos portos subsequentes, uma vez que as janelas de atracação são planejadas considerando o tempo de operação mais longo. Este fenômeno pode ser observado na viagem 10 do navio Nordamelia, na forma de sucessivas omissões de todos os portos, causando a perda de uma viagem inteira e, mais crítico, a sobreposição entre os dois navios que compõe este anel. A tabela 27 mostra que, devido a uma longa operação em Buenos Aires, derivado de uma produtividade total bastante aquém do esperado, aliado a um pico de volume, houve o cancelamento de todas as conexões subsequentes, até a retomada da programação em Rosario, já na viagem posterior.

Tabela 27 - Perda da viagem Nordamelia 10 e 11 norte

\begin{tabular}{|c|c|c|c|c|c|c|c|c|c|}
\hline Viagem & Direção & Porto & Omissão & $\begin{array}{c}\text { Volume } \\
\text { (Mov.) }\end{array}$ & $\begin{array}{l}\text { Guindastes } \\
\text { (Quantidade) }\end{array}$ & $\begin{array}{c}\text { Prod. por } \\
\text { Guindaste } \\
\text { (Mov./h) }\end{array}$ & $\begin{array}{c}\text { Espera não-op. } \\
\text { (h) }\end{array}$ & $\begin{array}{c}\text { Tempo de } \\
\text { Operação } \\
\text { (h) }\end{array}$ & $\begin{array}{c}\text { Tempo Total } \\
\text { (h) }\end{array}$ \\
\hline 9 & Norte & Buenos Aires & & 182 & 0,8 & 19,6 & 6,0 & 12,0 & 18,0 \\
\hline 9 & Norte & Zarate & & 1.540 & 1,9 & 20,8 & 4,1 & 38,4 & 42,5 \\
\hline 9 & Norte & Rosario & & 626 & 2,0 & 11,4 & 3,2 & 27,9 & 31,1 \\
\hline 9 & Sul & Itapoa & Y & 657 & & & & & \\
\hline 9 & Sul & Santos (BTP & & 314 & 1,0 & 26,0 & 5,2 & 12,1 & 17,3 \\
\hline 9 & Sul & Santos (SBSA) & & 1.478 & 2,9 & 21,0 & 4,3 & 24,2 & 28,5 \\
\hline 10 & Norte & Buenos Aires & & 512 & 1,0 & 16,9 & 2,7 & 31,8 & 34,5 \\
\hline 10 & Norte & Zarate & Y & 521 & & & & & \\
\hline 10 & Norte & Rosario & Y & 506 & & & & & \\
\hline 10 & Sul & Itapoa & Y & 582 & & & & & \\
\hline 10 & Sul & Santos (BTP & $Y$ & 287 & & & & & \\
\hline 10 & Sul & Santos (SBSA) & $Y$ & 1.355 & & & & & \\
\hline 11 & Norte & Buenos Aires & $Y$ & 393 & & & & & \\
\hline 11 & Norte & Zarate & Y & 821 & & & & & \\
\hline 11 & Norte & Rosario & & 582 & 2,0 & 13,7 & 6,3 & 21,3 & 27,6 \\
\hline 11 & Sul & Itapoa & $Y$ & 753 & & & & & \\
\hline 11 & Sul & Santos (BTP & & 219 & 1,0 & 31,4 & 3,7 & 6,3 & 10,0 \\
\hline 11 & Sul & Santos (SBSA) & & 1.162 & 3,0 & 28,6 & 3,1 & 14,8 & 17,9 \\
\hline
\end{tabular}

Fonte: Autor

O desmedido atraso na saída de Buenos Aires resultou na chegada atrasada ao porto de Zarate que, consequentemente, foi omitido. Porém, como a proforma considera 42 horas de operação neste porto, enquanto o tempo de navegação até Rosario é de apenas 10 horas, o atraso 
observado nos dois primeiros portos se transforma em chegada demasiadamente antecipada à próxima escala, além das 36 horas pré-janela consideradas aceitáveis para aguardar a atracação. Assim, uma nova omissão acontece e, daí em diante, o fenômeno se repete pelos próximos 5 portos, até o restabelecimento do serviço novamente em Zarate, em concomitância com a escala do segundo navio, ocorrendo no mesmo momento, no mesmo porto.

Esta situação deve ser evitada a todo custo, pois a sobreposição de dois navios é a situação mais prejudicial possível, rompendo completamente a estrutura semanal do serviço e provendo capacidade excessiva a cada escala.

\subsubsection{Anel 4}

O anel que tem como principal objetivo a conexão ao porto de Vitória mostrou-se um dos mais regulares, com poucas omissões ou chegadas fora de janela em seus portos principais, Santos e Vitória, como mostra a tabela 28.

Tabela 28 - Omissões e chegadas fora de janela no anel 4

\begin{tabular}{ccc} 
Porto & Omissões & Fora de Janela \\
\hline Santos SBSA & 2 & \\
Santos EMB & 13 & \\
Rio de Janeiro & 5 & \\
Vitória & & 4 \\
\hline
\end{tabular}

Fonte: Autor

A principal ressalva fica por conta da escala no terminal Embraport do porto de Santos, que atingiu 13 omissões durante o ano simulado, o que representa $25 \%$ das escalas anuais desta localidade. Estas omissões são decorrentes de repentinas quedas de produtividade na escala anterior, no terminal Santos Brasil, uma vez que os volumes movimentados se mantiveram estáveis.

Devido à proforma original deste anel considerar um tempo bastante pequeno para a escala no terminal Santos Brasil, qualquer oscilação que incorra em mais de 20 horas de operação acarreta a perda da janela para atracação no outro terminal do complexo santista. Neste caso, contudo, embora à primeira vista pareça subdimensionamento do tempo de escala no primeiro terminal, a Santos Brasil é um dos melhores terminais do país, com elevada produtividade e eficiência, não raro ultrapassando a marca de 100 movimentos por hora. Quedas na produtividade total para valores abaixo de 60 movimentos por hora não devem ser aceitos 
pelo armador neste terminal, devido ao nível de excelência atingido pelo mesmo. A tabela 29 mostra um resumo dos indicadores operacionais das escalas no terminal Santos Brasil que incorreram, posteriormente, em omissão no Embraport.

Tabela 29 - Escalas na Santos Brasil com elevado tempo de operação

\begin{tabular}{ccccccc} 
Viagem & $\begin{array}{c}\text { Volume } \\
\text { (Mov.) }\end{array}$ & $\begin{array}{c}\text { Guindastes } \\
\text { (Quantidade) }\end{array}$ & $\begin{array}{c}\text { Prod. por } \\
\text { Guindaste } \\
\text { (Mov./h) }\end{array}$ & $\begin{array}{c}\text { Prod. Total } \\
\text { (Mov./h) }\end{array}$ & $\begin{array}{c}\text { Tempo de } \\
\text { Operação } \\
\text { (h) }\end{array}$ & $\begin{array}{c}\text { Tempo } \\
\text { Total } \\
\text { (h) }\end{array}$ \\
\hline $\mathbf{1 4}$ & 962 & 3,3 & 14,3 & 47,6 & 20,2 & 24,8 \\
$\mathbf{1 8}$ & 959 & 2,9 & 17,8 & 52,1 & 18,4 & 29,1 \\
$\mathbf{2 2}$ & 694 & 1,5 & 26,6 & 40,3 & 17,2 & 24,5 \\
$\mathbf{2 4}$ & 987 & 2,4 & 25,2 & 60,9 & 16,2 & 24,8 \\
$\mathbf{2 7}$ & 918 & 2,4 & 18,9 & 46,0 & 20,0 & 23,1 \\
$\mathbf{3 1}$ & 916 & 2,5 & 18,8 & 47,4 & 19,3 & 21,9 \\
$\mathbf{3 4}$ & 1,162 & 2,1 & 30,8 & 64,3 & 18,1 & 23,7 \\
$\mathbf{3 6}$ & 829 & 1,6 & 24,5 & 39,9 & 20,8 & 22,0 \\
$\mathbf{4 1}$ & 828 & 2,3 & 21,8 & 50,9 & 16,3 & 22,7 \\
$\mathbf{4 2}$ & 888 & 1,8 & 23,2 & 41,8 & 21,2 & 24,0
\end{tabular}

Fonte: Autor

Por se tratar de um anel operado por uma empresa parceira, o armador estudado nesta pesquisa, dono dos demais 4 anéis, não tem nenhuma ingerência sobre a operação deste anel e não participa das ações de recuperação de programação ou negociações de condições operacionais com os terminais, permanecendo totalmente dependente das ações do parceiro. Vale mencionar, ainda, que ações como aumento ou diminuição de velocidade ou omissão de escalas não acarretam impactos financeiros para o armador deste estudo, uma vez que o espaço nos navios deste parceiro são comprados com base em um valor fixo, acordado em contrato, isolando, assim, o risco inerente ao aumento dos custos operacionais única e exclusivamente ao parceiro, até o momento em que as cláusulas do acordo sejam revisitados, usualmente a cada trimestre.

\subsubsection{Anel 5}

O quinto anel do serviço escala dois dos portos com maiores restrições operacionais na costa brasileira: São Luiz e Vila do Conde. São portos de infraestrutura bastante precária, providos apenas de MHC, que tem performance operacional muito abaixo dos modernos STS.

Os resultados da simulação deste anel mostram com precisão este cenário, com diversas disrupções operacionais e seguidas chegadas fora de janela nos portos de Pecém e Vila do Conde, como mostra a tabela 30 . 
Tabela 30 - Omissões e chegadas fora de janela no anel 5

\begin{tabular}{ccc} 
Porto & Omissões & Fora de Janela \\
\hline $\begin{array}{c}\text { Pecem } \\
\text { Vila do Conde }\end{array}$ & & 40 \\
São Luiz & 11 & 37
\end{tabular}

Fonte: Autor

Analisando-se mais detalhadamente, é possível notar que o porto de São Luiz tem grande contribuição para a baixa performance operacional deste anel, pois ao apresentar a menor produtividade portuária da costa brasileira, em torno de 10 movimentos por hora, qualquer pequena variação do volume movimentado significa diversas horas a mais parado no porto, como evidenciam os dados da tabela 31 , contendo os volumes, produtividades e tempos de operação das primeiras 26 escalas neste porto. Verifica-se que o incremento de 100 unidades representa mais de 10 horas adicionais de escala, ao passo que em outros portos, tal incremento acrescentaria pouco mais de 1,5 hora (por exemplo Santos, Itapoa e até mesmo Pecém, que atingem produtividades médias na ordem de 60 movimentos por hora). Tamanha sensibilidade, aliada ao fato de que a proforma deste anel considera poucas horas para a escala de São Luiz, contribuem fortemente para a consistente chegada fora de janela em Pecém. 
Tabela 31 - Primeiras 26 escalas em São Luiz

\begin{tabular}{|c|c|c|c|c|c|c|}
\hline \multicolumn{7}{|c|}{ São Luiz } \\
\hline Viagem & Omissão & $\begin{array}{c}\text { Volume } \\
\text { (Mov.) }\end{array}$ & $\begin{array}{c}\text { Prod. } \\
\text { (Mov./h) }\end{array}$ & $\begin{array}{l}\text { T. Op. } \\
\text { (h) }\end{array}$ & $\begin{array}{c}\text { Tempo Total } \\
\text { (h) } \\
\end{array}$ & $\begin{array}{c}\text { Tempo Total } \\
\text { (h) }\end{array}$ \\
\hline 1 & & 137 & 8,0 & 17,1 & 6,8 & 23,9 \\
\hline 2 & & 134 & 10,9 & 12,3 & 7,0 & 19,3 \\
\hline 3 & Sim & 279 & & & & \\
\hline 4 & & 106 & 11,3 & 9,4 & 5,1 & 14,5 \\
\hline 5 & & 118 & 7,4 & 16,0 & 5,6 & 21,6 \\
\hline 6 & & 98 & 8,7 & 11,3 & 5,6 & 16,8 \\
\hline 7 & & 136 & 8,9 & 15,3 & 3,6 & 18,9 \\
\hline 8 & & 57 & 7,1 & 8,0 & 6,4 & 14,4 \\
\hline 9 & & 170 & 8,3 & 20,5 & 8,3 & 28,8 \\
\hline 10 & & 149 & 12,0 & 12,4 & 5,0 & 17,4 \\
\hline 11 & & 131 & 9,1 & 14,4 & 3,3 & 17,7 \\
\hline 12 & & 172 & 5,8 & 29,9 & 3,4 & 33,3 \\
\hline 13 & Sim & 172 & & & & \\
\hline 14 & & 138 & 8,6 & 16,1 & 5,2 & 21,3 \\
\hline 15 & & 265 & 9,2 & 28,7 & 7,5 & 36,1 \\
\hline 16 & & 133 & 10,4 & 12,8 & 5,1 & 17,9 \\
\hline 17 & & 198 & 9,0 & 22,1 & 3,6 & 25,7 \\
\hline 18 & & 188 & 8,9 & 21,2 & 4,1 & 25,3 \\
\hline 19 & & 47 & 8,6 & 5,4 & 4,3 & 9,7 \\
\hline 20 & & 237 & 11,0 & 21,6 & 4,6 & 26,2 \\
\hline 21 & Sim & 25 & & & & \\
\hline 22 & & 212 & 10,7 & 19,8 & 3,1 & 22,9 \\
\hline 23 & & 18 & 9,1 & 2,0 & 5,5 & 7,5 \\
\hline 24 & & 70 & 8,0 & 8,7 & 4,0 & 12,7 \\
\hline 25 & & 158 & 10,6 & 14,9 & 5,7 & 20,6 \\
\hline 26 & Sim & 89 & & & & \\
\hline
\end{tabular}

Fonte: Autor

Em Pecém, por outro lado, há grande regularidade das operações, com a maioria das escalas com tempo total de operação bastante próximos às 14 horas previstas em proforma. Devido a esta regularidade visualizada em Pecém e o fato de as operações estarem consistentemente atrasadas devido à chegada tardia de São Luiz, a embarcação também chega fora de sua janela em Vila do Conde, uma consequência da propagação de atrasos acumulados. Neste último porto, também existe boa consistência operacional, com tempo total sempre em torno de 24 horas. Ainda assim, pode-se verificar diversas oscilações grandes no tempo total de operação, também decorrentes da baixa produtividade deste terminal, atreladas a aumentos repentinos de volume. Um resumo das primeiras 26 escalas em Pecém e Vila do Conde é apresentado na tabela 32 . 
Tabela 32 - Primeiras 26 escalas em Pecém e Vila do Conde

\begin{tabular}{|c|c|c|c|c|c|c|}
\hline \multirow[b]{2}{*}{ Viagem } & \multicolumn{3}{|c|}{ Pecém } & \multicolumn{3}{|c|}{ Vila do Conde } \\
\hline & $\begin{array}{c}\text { Volume } \\
\text { (Mov.) }\end{array}$ & $\begin{array}{c}\text { Prod. } \\
\text { (Mov./h) }\end{array}$ & $\begin{array}{l}\text { T. Total } \\
\text { (h) }\end{array}$ & $\begin{array}{c}\text { Volume } \\
\text { (Mov.) }\end{array}$ & $\begin{array}{l}\text { Prod. } \\
\text { (Mov./h) }\end{array}$ & $\begin{array}{l}\text { T. Total } \\
\text { (h) }\end{array}$ \\
\hline 1 & 434 & 58,4 & 9,4 & 381 & 33,7 & 15,1 \\
\hline 2 & 724 & 40,2 & 21,5 & 507 & 31,3 & 20,2 \\
\hline 3 & 765 & 53,0 & 18,8 & 799 & 29,6 & 36,0 \\
\hline 4 & 512 & 55,4 & 10,9 & 544 & 21,2 & 30,5 \\
\hline 5 & 485 & 54,5 & 13,9 & 379 & 28,6 & 25,5 \\
\hline 6 & 375 & 61,8 & 9,3 & 499 & 28,4 & 22,5 \\
\hline 7 & 336 & 64,3 & 8,2 & 449 & 28,1 & 25,7 \\
\hline 8 & 465 & 48,6 & 13,1 & 399 & 32,9 & 16,3 \\
\hline 9 & 310 & 58,3 & 8,3 & 523 & 26,6 & 35,2 \\
\hline 10 & 381 & 56,9 & 12,1 & 306 & 33,9 & 14,5 \\
\hline 11 & 307 & 61,2 & 8,3 & 368 & 24,9 & 22,4 \\
\hline 12 & 584 & 60,0 & 11,9 & 360 & 24,9 & 18,9 \\
\hline 13 & 627 & 55,7 & 15,0 & 578 & 31,0 & 23,2 \\
\hline 14 & 612 & 60,6 & 13,5 & 367 & 34,6 & 28,5 \\
\hline 15 & 426 & 50,1 & 13,9 & 343 & 24,3 & 21,6 \\
\hline 16 & 585 & 55,9 & 14,1 & 228 & 30,8 & 11,8 \\
\hline 17 & 133 & 59,8 & 4,6 & 425 & 29,1 & 20,3 \\
\hline 18 & 550 & 55,6 & 13,1 & 632 & 33,2 & 24,5 \\
\hline 19 & 448 & 58,1 & 11,2 & 465 & 24,0 & 22,0 \\
\hline 20 & 632 & 65,2 & 13,1 & 735 & 33,3 & 25,9 \\
\hline 21 & 528 & 51,8 & 13,9 & 435 & 28,2 & 21,9 \\
\hline 22 & 571 & 63,8 & 11,6 & 591 & 29,3 & 30,9 \\
\hline 23 & 397 & 54,0 & 12,1 & 399 & 34,9 & 15,7 \\
\hline 24 & 710 & 55,1 & 16,3 & 486 & 28,0 & 23,8 \\
\hline 25 & 473 & 53,2 & 11,2 & 459 & 32,9 & 20,1 \\
\hline 26 & 644 & 56,0 & 15,9 & 656 & 27,4 & 38,8 \\
\hline
\end{tabular}

Fonte: Autor

Dado que a proforma deste anel considera um buffer bastante grande entre os portos de Vila do Conde e São Luiz, esta propagação de atrasos acumulados acaba sendo corrigida no próprio retorno a São Luiz, uma vez que a simulação mostra que apenas 11 em 52 escalas acabaram omitidas nesta localidade, número baixo se levado em consideração que mais de $70 \%$ das escalas nos outros portos chegam fora da janela prevista.

Para corrigir este cenário, faz-se necessária a realocação do buffer, que, se colocado entre São Luiz e Pecém, garantiria a chegada da embarcação dentro da janela nos portos de Pecém e Vila do Conde, sem prejudicar a chegada em São Luiz, visto que os dois primeiros 
apresentam maior regularidade e consistência. A alocação do buffer após São Luiz também permite a flexibilidade de o armador ajustar sua velocidade de navegação no caminho a Pecém, decidindo por uma navegação mais econômica ou mais célere, de modo a garantir a chegada na janela, independentemente de quando sairá de São Luiz, a maior incógnita neste serviço.

Por fim, vale ainda destacar que por ser um serviço com apenas 1 navio, cada viagem deve ser completada dentro de uma semana e, consequentemente, são esperadas 52 viagens no ano. Embora as 52 viagens tenham de fato acontecido, 19 delas não foram capazes de ser finalizadas dentro do período de 168 horas. Isto mostra que, mesmo o reposicionamento do buffer não é inteiramente capaz de garantir a plena confiabilidade do planejamento deste anel, severamente afetado pelas condições operacionais dos portos que opera.

Nesta situação, como não são esperados em curto prazo investimentos em infraestrutura nestas localidades, o armador recorre a algumas manobras, visando enquadrar o tempo total da viagem dentro do período semanal, como exemplo, aumento de velocidade em alguns trechos, cut-and-run (manobra na qual a operação é subitamente interrompida e o navio segue viagem, deixando cargas para trás), ou até mesmo cancelar alguma escala. A tabela 28 mostra as 15 primeiras viagens deste serviço, dentre as quais apenas 9 finalizaram dentro do período de 168 horas requerido para um serviço semanal.

Tabela 33 - Tempo necessário para finalização de viagens no anel 5

\begin{tabular}{cccccc} 
Viagem & $\begin{array}{c}\text { T. Porto } \\
\text { (h) }\end{array}$ & $\begin{array}{c}\text { T. Mar } \\
\text { (h) }\end{array}$ & $\begin{array}{c}\text { T. Viagem } \\
\text { (h) }\end{array}$ & $\begin{array}{c}\text { Delta vs } \\
\text { Semana }\end{array}$ & $\begin{array}{c}\text { Finalizou na } \\
\text { semana? }\end{array}$ \\
\hline 1 & 48,3 & 108,9 & 157,3 & 10,7 & Sim \\
2 & 61,0 & 108,9 & 170,0 & $-2,0$ & Não \\
3 & 54,9 & 108,9 & 163,8 & 4,2 & Sim \\
4 & 55,8 & 108,9 & 164,8 & 3,2 & Sim \\
5 & 61,0 & 108,9 & 170,0 & $-2,0$ & Não \\
6 & 48,6 & 108,9 & 157,6 & 10,4 & Sim \\
7 & 52,7 & 108,9 & 161,7 & 6,3 & Sim \\
8 & 43,8 & 108,9 & 152,7 & 15,3 & Sim \\
9 & 72,3 & 108,9 & 181,2 & $-13,2$ & Não \\
10 & 44,0 & 108,9 & 152,9 & 15,1 & Sim \\
11 & 48,4 & 108,9 & 157,4 & 10,6 & Sim \\
12 & 64,1 & 108,9 & 173,0 & $-5,0$ & Não \\
13 & 38,2 & 108,9 & 147,1 & 20,9 & Sim \\
14 & 63,3 & 108,9 & 172,2 & $-4,2$ & Não \\
15 & 71,7 & 108,9 & 180,6 & $-12,6$ & Não
\end{tabular}

Fonte: Autor

Destaca-se que, como uma das premissas deste modelo foi a manutenção de velocidades constantes de navegação, o tempo navegado é rigorosamente o mesmo em todas as viagens. 
Sugere-se, assim, como futura investigação, a variação de velocidades em cada viagem, de modo a garantir a finalização de cada viagem dentro do período de 1 semana, levando-se em consideração, naturalmente, os efeitos positivos e negativos de consumo de combustível e comparando qual estratégia seria economicamente mais interessante para o armador. 


\section{CONCLUSÃO E SUGESTÕES}

Com o intuito de se estudar a influência das diversas variabilidades inerentes às operações marítimas e aplicado à realidade da Cabotagem brasileira, desenvolveu-se esta simulação a eventos discretos, na qual foi modelado o serviço completo prestado por um grande armador nacional, a partir das proformas estabelecidas pela companhia. Objetivou-se, ainda, validar a conformidade destes planejamentos aos requerimentos de pontualidade e qualidade das operações, antevendo e corrigindo possíveis adversidades encontradas.

Os resultados das simulações confirmaram que, uma vez consideradas as curvas estatísticas de variação das diversas variáveis que compõe o sistema, observa-se grande fragilidade quanto à manutenção da pontualidade do serviço, como foi o caso dos anéis 3 e 5 , bastante afetados pela baixa eficiência dos portos argentinos e em São Luiz, respectivamente.

Além disto, foram identificados casos de falta de aderência das proformas à realidade das operações, do ponto de vista histórico, visto que, em alguns portos, houve subestimação do tempo de operação, como em Pecém no anel 2 e Rosario no anel 3, ou sobrestimação do mesmo, como ocorreu em Manaus no anel 1, levando as embarcações a atrasarem ou adiantarem, respectivamente, sua chegada ao próximo porto com frequência.

As conclusões da primeira análise possibilitaram a tomada de decisões pontuais de forma eficaz, como comprovados através de novas simulações, em que os parâmetros de velocidade foram corrigidos para os trechos problemáticos, resultando em uma quantidade de omissões mais baixa. Embora tenha atingido, mesmo que parcialmente, o objetivo das alterações de velocidade, tal solução apresenta um impacto financeiro à empresa operadora, que muitas vezes pode ser julgada economicamente inviável. No anel 1, a redução de velocidade de navegação foi eficiente ao melhorar a confiabilidade do serviço aliado a uma redução no custo de combustível. Em contrapartida, nos outros anéis, o resultado foi inverso: embora a pontualidade tenha sido restabelecida, há custo adicional em decorrência ao aumento de velocidade de navegação.

O modelo, contudo, também apresenta suas limitações, principalmente no que tange ao modelamento das filas de atracação dos portos. Devido à dificuldade neste modelamento, aliada a falta de dados confiáveis para o mesmo, decidiu-se estabelecer lógicas que privilegiassem a integridade do planejamento, omitindo escalas muito atrasadas ou adiantadas. Esta importante regra permitiu a identificação das dificuldades operacionais de forma rápida, atendendo ao propósito deste trabalho, mas incute restrições ao uso deste modelo para previsão de demanda de volumes e estimativa do resultado econômico do serviço, uma vez que esta estratégia 
incrorreria em multas e perdas de carga, que não foram arbitrados neste trabalho. Uma segunda restrição deste trabalho está relacionada à ausência de variação das velocidades de navegação conforme a demanda por mais ou menos agilidade, dependendo do tempo de navegação estimado para determinado trecho. O modelo foi elaborado com velocidades constantes ao longo do período analisado, não possibilitando ajustes dinâmicos durante a simulação.

Ainda que algumas limitações estejam presentes, as conclusões acima permitem afirmar que a simulação conseguiu refletir as dificuldades operacionais deste sistema de cabotagem, quando submetido às oscilações nas condições operacionais dos portos que escala, mostrandose como uma benéfica ferramenta à tomada de decisão no âmbito da pontualidade e retomada de planejamentos atrasados ou adiantados.

Sugere-se, por fim, como futuras contribuições a inclusão da fila de atracação dos portos e um detalhamento dos critérios para a decisão acerca da espera ou não pela atracação, quando a chegada da embarcação ao porto ocorrer fora do período de janela e sua tolerância. Este modelo pode ou não incluir parâmetros financeiros, sendo recomendado que o faça, possibilitando a ampliação do mesmo para arbitragens não somente operacionais, mas também econômicas. Além disto, aconselha-se a investigar a influência da variação das velocidades ao longo dos trechos navegados, com o intuito de não somente aumentar a confiabilidade da proforma estabelecida, mas também de se melhorar o consumo total de combustível, medida que apresenta grande importância financeira e ambiental. Por último, lembra-se que este trabalho utilizou como base de modelamento proformas elaboradas pela empresa através de metodologia empírica, sem utilizar outras metodologias quantitativas mais modernas. Desta forma, visualiza-se a possibilidade de investigações vindouras se aprofundarem na combinação entre modelos de otimização e simulação, constituindo uma poderosa ferramenta para criação de serviços melhores, otimizados e também validados para as adversas condições operacionais inerentes ao setor. 


\section{REFERÊNCIAS}

AGARWAL, R.; ERGUN, Ö. Ship Scheduling and Network Design for Cargo Routing in Liner Shipping. Transportation Science, v. 42, n. 2, p. 175-196, 2008.

ANTAQ. Convênio entre a República Federativa do Brasil e a República Oriental do Uruguai sobre Transporte Marítimo. 1976.

ANTAQ. Acordo sobre Transportes Marítimos entre a República Federativa do Brasil e a República Argentina. 1990.

AYDIN, N.; LEE, H.; MANSOURI, S. A. Speed optimization and bunkering in liner shipping in the presence of uncertain service times and time windows at ports. European Journal of Operational Research, v. 259, n. 1, p. 143-154, 2017.

BANKS, J. et al. Discrete-event system simulation. $5^{\text {a }}$ Edição ed. Upper Saddle River: Pearson Education, Inc., 2009.

BELL, M. G. H. et al. A frequency-based maritime container assignment model.

Transportation Research Part B: Methodological, v. 45, n. 8, p. 1152-1161, 2011.

BENDALL, H. B.; STENT, A. F. A Scheduling Model for a High Speed Containership Service: A Hub and Spoke Short-Sea Application. International journal of maritime economics, v. 3, n. 3, p. 262-277, 2001.

BOFFEY, T. B. et al. Two Approaches to Scheduling Container Ships with an Application to the North Atlantic Route. Journal of the Operational Research Society, v. 30, n. 5, p. 413$425,1979$.

BRASIL. Lei n. 9.432/97. Dispõe sobre a ordenação do transporte aquaviário e dá outras providências, jan. 1997.

BRASIL. Lei n. 10.893/04. Dispõe sobre o Adicional ao Frete para a Renovação da Marinha Mercante - AFRMM e o Fundo da Marinha Mercante - FMM, e dá outras providências., jul. 2004.

BROUER, B. D. et al. The Vessel Schedule Recovery Problem (VSRP) - A MIP model for handling disruptions in liner shipping. European Journal of Operational Research, v. 224, n. 2, p. 362-374, 2013.

BROUER, B. D.; PISINGER, D.; SPOORENDONK, S. Liner shipping cargo allocation with repositioning of empty containers. Infor, v. 49, n. 2, p. 109-124, 2011.

CALATAYUD, A.; MANGAN, J.; PALACIN, R. Vulnerability of international freight flows 
to shipping network disruptions: A multiplex network perspective. Transportation Research Part E: Logistics and Transportation Review, v. 108, n. November, p. 195-208, 2017.

CASACA, A. C. P. et al. Domestic short sea shipping services in Brazil: Competition by enhancing logistics integration. International Journal of Shipping and Transport Logistics, v. 9, n. 3, p. 280-303, 2017.

CHO, S. C.; PERAKIS, A. N. Optimal liner fleet routeing strategies. Maritime Policy and Management, v. 23, n. 3, p. 249-259, 1996.

CHRISTIANSEN, M.; FAGERHOLT, K. Robust ship scheduling with multiple time windows. Naval Research Logistics, v. 49, n. 6, p. 611-625, 2002.

CHUANG, T. N. et al. Planning the route of container ships: A fuzzy genetic approach. Expert Systems with Applications, v. 37, n. 4, p. 2948-2956, 2010.

CHUNG, C.; CHIANG, C. The Critical Factors : An Evaluation of Schedule Reliability in Liner Shipping. International Journal of Operations Research, v. 8, n. 4, p. 3-10, 2011.

DAGANZO, C. F. et al. Port efficiency and Brazilian exports: A quantitative assessment of the impact of turnaround time. World Economy, v. 41, n. 1251, p. 1-9, 2018.

DE OLIVEIRA, A. L. R.; DE SÁ PORTO, P. C. Serviços de cabotagem no Brasil: Principais vantagens e desafios atuais. Espacios, v. 37, n. 8, p. 11, 2016.

DIAS, J. C. D. S. Gestão e operação portuária: experiência em cingapura. Brasília: Editora ANTAQ, 2013.

FAGERHOLT, K. Optimal fleet design in a ship routing problem. International Transactions in Operational Research, v. 6, n. 5, p. 453-464, 1999.

FAGERHOLT, K. Designing optimal routes in a liner shipping problem. Maritime Policy \& Management, v. 31, n. 4, p. 259-268, 2004.

FAGERHOLT, K.; JOHNSEN, T. A. V.; LINDSTAD, H. Fleet deployment in liner shipping: A case study. Maritime Policy and Management, v. 36, n. 5, p. 397-409, 2009.

GELAREH, S.; MENG, Q. A novel modeling approach for the fleet deployment problem within a short-term planning horizon. Transportation Research Part E: Logistics and Transportation Review, v. 46, n. 1, p. 76-89, 2010.

GELAREH, S.; NICKEL, S.; PISINGER, D. Liner shipping hub network design in a competitive environment. Transportation Research Part E: Logistics and Transportation Review, v. 46, n. 6, p. 991-1004, 2010. 
GELAREH, S.; PISINGER, D. Fleet deployment, network design and hub location of liner shipping companies. Transportation Research Part E: Logistics and Transportation Review, v. 47, n. 6, p. 947-964, 2011.

GUEDES, G. Greve de caminhoneiros colocou Petrobras em xeque e expôs dependência rodoviáriaBrasil Econômico, 2018. Disponível em: $<$ https://economia.ig.com.br/2018-1219/greve-dos-caminhoneiros-retrospectiva.html>

HALFF, A.; YOUNES, L.; BOERSMA, T. The likely implications of the new IMO standards on the shipping industry. Energy Policy, v. 126, n. November 2018, p. 277-286, 2019.

JARAMILLO, D. I.; PERAKIS, A. N. Fleet deployment optimization for liner shipping part 2. Implementation and results. Maritime Policy and Management, v. 18, n. 4, p. 235-262, 1991.

KARLAFTIS, M. G.; KEPAPTSOGLOU, K.; SAMBRACOS, E. Containership routing with time deadlines and simultaneous deliveries and pick-ups. Transportation Research Part E: Logistics and Transportation Review, v. 45, n. 1, p. 210-221, 2009.

KAVUSSANOS, M. G.; VISVIKIS, I. D. Shipping freight derivatives: a survey of recent evidence. Maritime Policy \& Management, v. 33, n. 3, p. 233-255, 2006.

KOENEN, M. Disruption Management : The Vessel Schedule Recovery Problem ( VSRP ) Bachelor Thesis Econometrics and Operational Research. [s.1.] Erasmus University Rotterdam, 2017.

KONTOVAS, C. A.; PSARAFTIS, H. N. The link between economy and environment in the post-crisis era: lessons learned from slow steaming. International Journal of Decision Sciences, Risk and Management, v. 3, n. 3/4, p. 311, 2011.

LANG, N.; VEENSTRA, A. A quantitative analysis of container vessel arrival planning strategies. OR Spectrum, v. 32, n. 3, p. 477-499, 2010.

LI, C.; QI, X.; SONG, D. Real-time schedule recovery in liner shipping service with regular uncertainties and disruption events. Transportation Research Part B: Methodological, v. 93, p. 762-788, 2016.

LIU, X.; YE, H.-Q.; YUAN, X.-M. Tactical planning models for managing container flow and ship deployment. Maritime Policy \& Management, v. 38, n. 5, p. 487-508, 2011.

LÓPEZ-BERMÚDEZ, B.; FREIRE-SEOANE, M. J.; GONZÁLEZ-LAXE, F. Efficiency and productivity of container terminals in Brazilian ports (2008-2017). Utilities Policy, v. 56, n. September 2018, p. 82-91, 2019. 
$<$ https:/hbswk.hbs.edu/item/the-truck-driver-who-reinvented-shipping $>$. Acesso em: 22 nov. 2020 .

MEDEIROS, R. L. et al. Cenários logísticos alternativos para a cabotagem do estado do Amazonas utilizando simulação computacional. Journal of Transport Literature, v. 9, n. 1, p. 60-64, 2015.

MEIJER, M.; MULDER, J.; VAN OOSTEROM, C. Erasmus School of Economics Designing robust liner shipping schedules : Optimizing recovery actions and buffer times. [s.1.] Erasmus University Rotterdam, 2016.

MENG, Q. et al. Containership Routing and Scheduling in Liner Shipping: Overview and Future Research Directions. Transportation Science, v. 48, n. 2, p. 265-280, 2014.

MENG, Q.; WANG, S. Liner shipping service network design with empty container repositioning. Transportation Research Part E: Logistics and Transportation Review, v. 47, n. 5, p. 695-708, 2011.

MENG, Q.; WANG, S.; LIU, Z. Network design for shipping service of large-scale intermodal liners. Transportation Research Record, n. 2269, p. 42-50, 2012.

MENG, Q.; WANG, T. A chance constrained programming model for short-term liner ship fleet planning problems. Maritime Policy and Management, v. 37, n. 4, p. 329-346, 2010.

MENG, Q.; WANG, T.; WANG, S. Short-term liner ship fleet planning with container transshipment and uncertain container shipment demand. European Journal of Operational Research, v. 223, n. 1, p. 96-105, 2012.

MULDER, J.; DEKKER, R. Designing robust liner shipping schedules: Optimizing recovery actions and buffer times. European Journal of Operational Research, v. 272, n. 1, p. 132$146,2019$.

NOTTEBOOM, T. E. The Time Factor in Liner Shipping Services. Maritime Economics \& Logistics, v. 8, n. 1, p. 19-39, 2006.

NOTTEBOOM, T. E.; VERNIMMEN, B. The effect of high fuel costs on liner service configuration in container shipping. Journal of Transport Geography, v. 17, n. 5, p. 325337, 2009.

PAIXAO CASACA, A. C. et al. The Brazilian cabotage market: a content analysis. International Journal of Shipping and Transport Logistics, v. 9, n. 5, p. 601, 2017.

PERAKIS, A. N.; JARAMILLO, D. I. Fleet deployment optimization for liner shipping part 1. background, problem formulation and solution approaches. Maritime Policy and Management, v. 18, n. 3, p. 183-200, 1991. 
PESENTI, R. Hierarchical resource planning for shipping companies. European Journal of Operational Research, v. 86, n. 1, p. 91-102, 1995.

POWELL, B. J.; PERAKIS, A. . N. Fleet deployment optimization for liner shipping: an integer programming model. Maritime Policy \& Management, v. 24, n. 2, p. 183-192, 1997.

RAJKOVIC, R. et al. The Costs of Container Transport Flow Between Far East and Serbia Using Different Liner Shipping Services. Logistics \& Sustainable Transport, v. 6, n. 1, p. 34-40, 2015.

RANA, K.; VICKSON, R. G. Routing Container Ships Using Lagrangean Relaxation and Decomposition. Transportation Science, v. 25, n. 3, p. 201-214, 1991.

RONEN, D. Cargo ships routing and scheduling: Survey of models and problems. European Journal of Operational Research, v. 12, n. 2, p. 119-126, 1983.

\section{SALIBY, E. TECNOLOGIA DE INFORMAÇÃO: USO DA SIMULAÇÃO PARA} OBTENÇÃO DE MELHORIAS EM OPERAÇÕES LOGÍSTICA. Disponível em: $<$ http://www.ilos.com.br/web/tecnologia-de-informacao-uso-da-simulacao-para-obtencao-demelhorias-em-operacoes-logisticas/>. Acesso em: 2 jun. 2019.

SALLEH, N. H. M. et al. Predicting a Containership's Arrival Punctuality in Liner Operations by Using a Fuzzy Rule-Based Bayesian Network (FRBBN). Asian Journal of Shipping and Logistics, v. 33, n. 2, p. 95-104, 2017.

SAMBRACOS, E. et al. Dispatching of small containers via coastal freight liners: The case of the Aegean Sea. European Journal of Operational Research, v. 152, n. 2, p. 365-381, 2004.

SANTOS, C. C. DE M.; LEAL JR, I. C.; FILHO, V. J. M. F. A Utilização da Simulação para Análise e Escolha de Modal de Transporte. p. 1-12, 2004.

SEABRA, F.; FLORES, G. P.; BALISTIERI, T. Perspectivas da Grande Cabotagem no Mercosul. Espacios, v. 38, n. 44, 2017.

SHINTANI, K. et al. The container shipping network design problem with empty container repositioning. Transportation Research Part E: Logistics and Transportation Review, v. 43, n. 1, p. 39-59, jan. 2007.

SILVEIRA, M. R.; JÚNIOR, N. F. F. A dinâmica do transporte marítimo de cabotagem e longo curso no Brasil: circulação do capital e modernizações. Geosul, v. 28, n. 55, p. 7, 2013.

SONG, D.-P.; DONG, J.-X. Cargo routing and empty container repositioning in multiple shipping service routes. Transportation Research Part B: Methodological, v. 46, n. 10, p. 
$1556-1575,2012$.

TING, S. C.; TZENG, G. H. An optimal containership slot allocation for liner shipping revenue management. Maritime Policy and Management, v. 31, n. 3, p. 199-211, 2004.

TONGZON, J. L. Determinants of port performance and efficiency. Transportation Research Part A: Policy and Practice, v. 29, n. 3, p. 245-252, 1995.

UNCTAD. Review of Maritime Transport. [s.l: s.n.].

VERNIMMEN, B.; DULLAERT, W.; ENGELEN, S. Schedule Unreliability in Liner Shipping: Origins and Consequences for the Hinterland Supply Chain. Maritime Economics \& Logistics, v. 9, n. 3, p. 193-213, 2007.

WANG, S.; MENG, Q. Schedule Design and Container Routing in Liner Shipping. Transportation Research Record: Journal of the Transportation Research Board, v. 2222, n. 1, p. 25-33, 2011.

WANG, S.; MENG, Q. Liner ship fleet deployment with container transshipment operations. Transportation Research Part E: Logistics and Transportation Review, v. 48, n. 2, p. 470-484, 2012a.

WANG, S.; MENG, Q. Sailing speed optimization for container ships in a liner shipping network. Transportation Research Part E: Logistics and Transportation Review, v. 48, n. 3, p. 701-714, 2012b.

WANG, S.; WANG, T.; MENG, Q. A note on liner ship fleet deployment. Flexible Services and Manufacturing Journal, v. 23, n. 4, p. 422-430, 2011.

WANG, Y.; MENG, Q.; DU, Y. Liner container seasonal shipping revenue management. Transportation Research Part B: Methodological, v. 82, p. 141-161, 2015.

YAN, S.; CHEN, C.-Y.; LIN, S.-C. Ship scheduling and container shipment planning for liners in short-term operations. Journal of Marine Science and Technology, v. 14, n. 4, p. 417-435, 23 dez. 2009.

YAO, Z.; NG, S. H.; LEE, L. H. A study on bunker fuel management for the shipping liner services. Computers and Operations Research, v. 39, n. 5, p. 1160-1172, 2012.

ZACHARIOUDAKIS, P. G. et al. Liner shipping cycle cost modelling, fleet deployment optimization and what-if analysis. Maritime Economics and Logistics, v. 13, n. 3, p. 278 297, 2011. 
shippingJournal of Transport Economics and Policy, 1978.

ZHANG, A.; LAM, J. S. L. Impacts of Schedule Reliability and Sailing Frequency on the Liner Shipping and Port Industry: Transportation Journal, v. 53, n. 2, p. 235, 2014.

ZHANG, A.; LAM, J. S. L. Daily Maersk's impacts on shipper's supply chain inventories and implications for the liner shipping industry. Maritime Policy \& Management, v. 42, n. 3, p. 246-262, 2015. 
ANEL 1

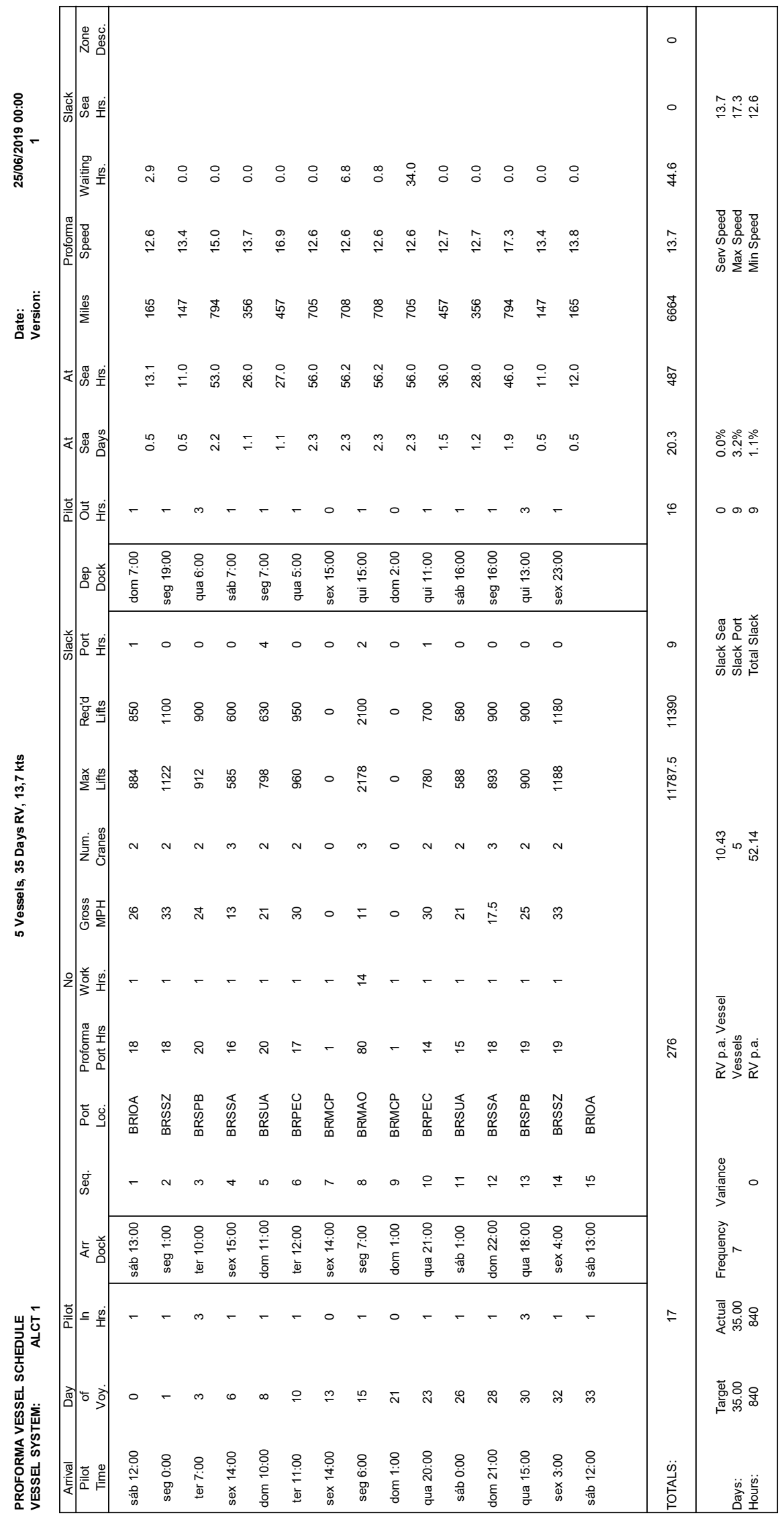


ANEL 2

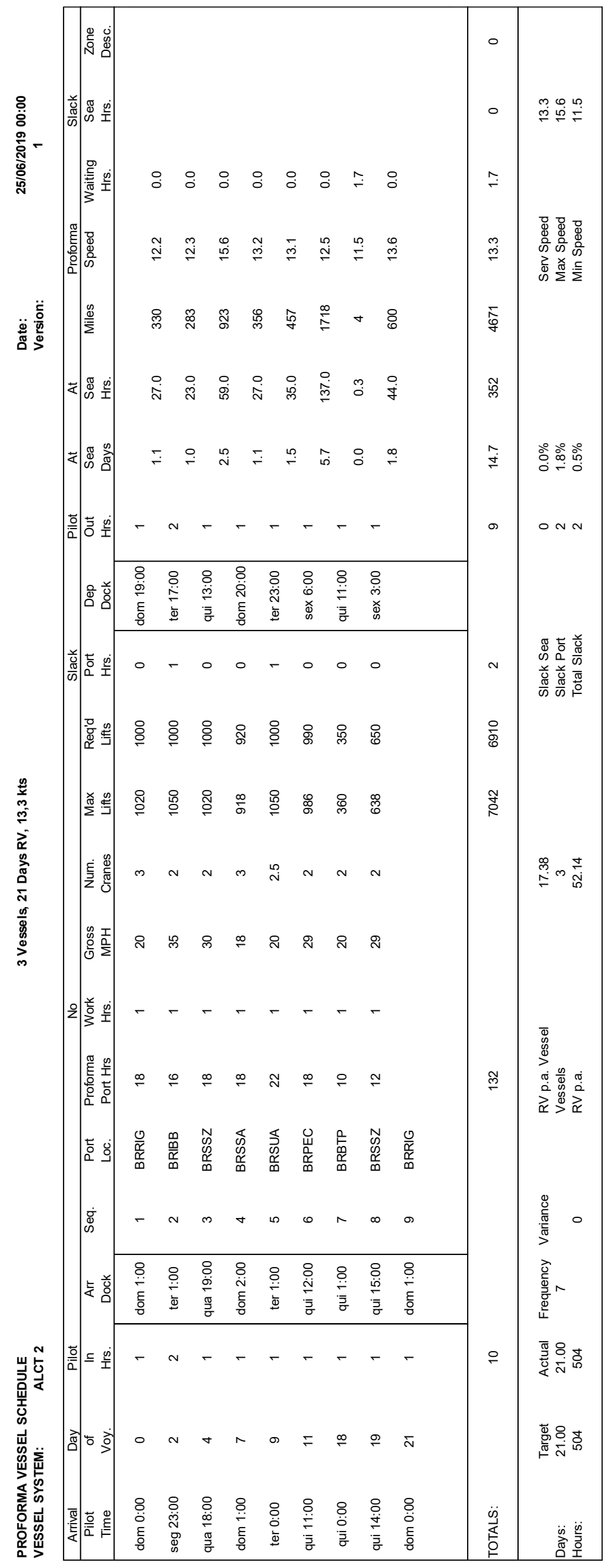


ANEL 3

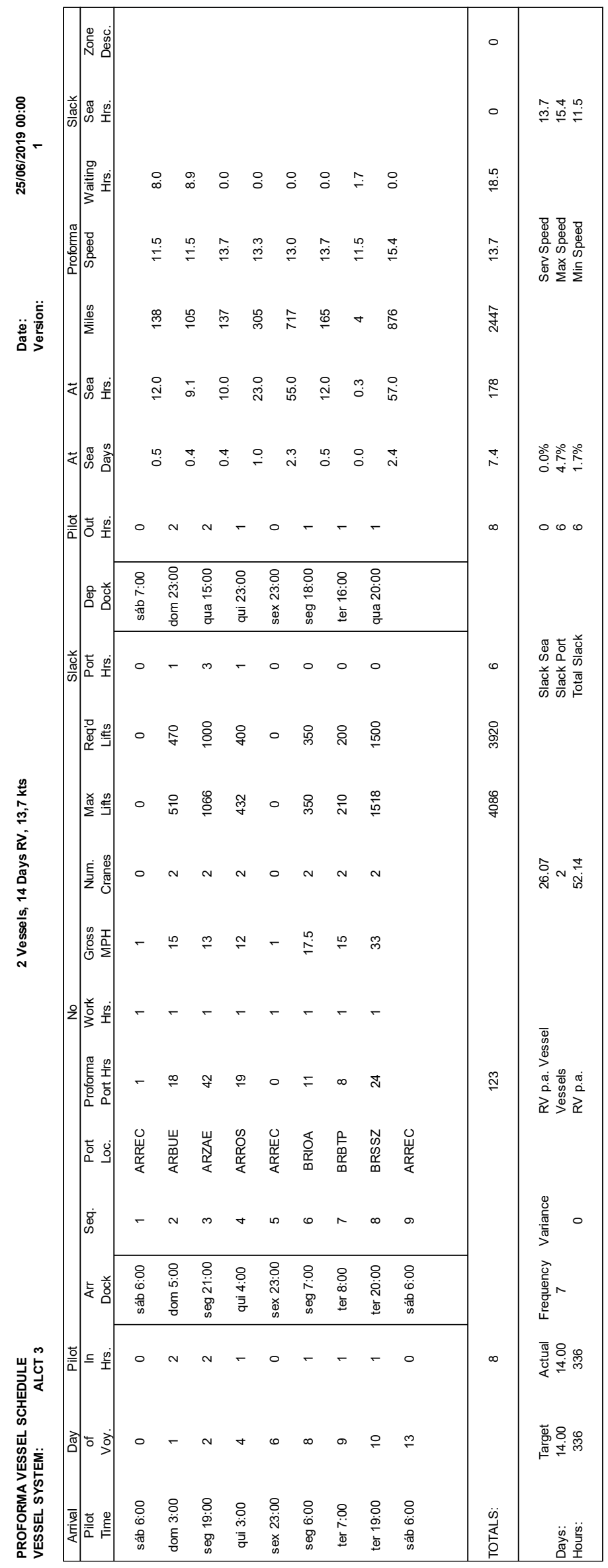


ANEL 5

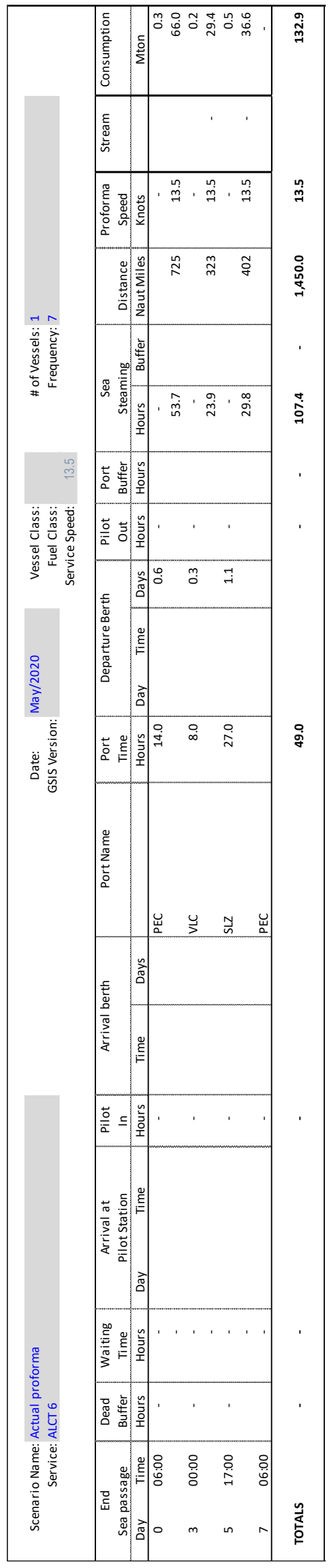




\section{APÊNDICE B - JANELAS DE ATRACAÇÃO}

\begin{tabular}{|c|c|c|c|c|c|c|c|c|}
\hline Anel & Porto & DOMINGO & SEGUNDA & TERÇA & QUARTA & QUINTA & SEXTA & SABAD \\
\hline 1 & IOA & & & & & & & \\
\hline 1 & SSZN & & & & & & & \\
\hline 1 & SPBN & & & & & & & \\
\hline 1 & SSAN & & & & & & & \\
\hline 1 & SUAN & & & & & & & \\
\hline 1 & PECN & & & & & & & \\
\hline 1 & MAO & & & & & & & \\
\hline 1 & PECS & & & & & & & \\
\hline 1 & SUAS & & & & & & & \\
\hline 1 & SSAS & & & & & & & \\
\hline 1 & SPBS & & & & & & & \\
\hline 1 & SSZS & & & & & & & \\
\hline 2 & RIG & & & & & & & \\
\hline 2 & IBB & & & & & & & \\
\hline 2 & SSZN & & & & & & & \\
\hline 2 & SSA & & & & & & & \\
\hline 2 & SUA & & & & & & & \\
\hline 2 & PEC & & & & & & & \\
\hline 2 & BTP & & & & & & & \\
\hline 2 & SSZS & & & & & & & \\
\hline 3 & BUE & & & & & & & \\
\hline 3 & ZAE & & & & & & & \\
\hline 3 & ROS & & & & & & & \\
\hline 3 & IOA & & & & & & & \\
\hline 3 & BTP & & & & & & & \\
\hline 3 & SSZ & & & & & & & \\
\hline 4 & SSZ & & & & & & & \\
\hline 4 & EMB & & & & & & & \\
\hline 4 & RIO & & & & & & & \\
\hline 4 & VIX & & & & & & & \\
\hline 6 & PEC & & & & & & & \\
\hline 6 & VLC & & & & & & & \\
\hline 6 & SLZ & & & & & & & \\
\hline
\end{tabular}

Legenda:

0 janela fechada, aguardando abertura

1 janela aberta

2 janela fechada, sem aguardo de nova janela 


\section{APÊNDICE C - DISTRIBUIÇÕES ESTATÍSTICAS}

\begin{tabular}{|c|c|c|c|}
\hline Sling & Porto & WaitPre & WaitPos \\
\hline ALCT1 & BRIOA & $\mathrm{P} 5(2.26,2.71)$ & $\mathrm{P} 6(2.64,23.4,22.1)$ \\
\hline ALCT1 & BRSSZN & $\mathrm{L}(2.23,2.81)$ & $(1 . / 0.513) *(-\operatorname{LN}(U(0.5,0.5))) *(-1 . / 2.22)$ \\
\hline ALCT1 & BRSPBN & $\mathrm{B}(0.633,1.37,0,15.2)$ & $\operatorname{ER}(1.85,4)$ \\
\hline ALCT1 & BRSSAN & $20 *(1 . /(1 .+\operatorname{EXP}(-(\mathrm{N}(0 ., 1)-1.01) / 0.555)))$. & $1.43 *(1 . /((1 . / \mathrm{U}(0.5,0.5))-1)) * *.(1 . / 8.22)$ \\
\hline ALCT1 & BRSUAN & $L(1.56,0.948)$ & $\mathrm{W}(2.25,1.82)$ \\
\hline ALCT1 & BRPECN & $\operatorname{ER}(1.85,5)$ & $\mathrm{P} 5(7.52,10.5)$ \\
\hline ALCT1 & BRMAO & $1.53 *(1 . /((1 . / \mathrm{U}(0.5,0.5))-1 .))^{* *(1 . / 3.15)}$ & $\operatorname{IG}(5.19,4.23)$ \\
\hline ALCT1 & BRPECS & $\mathrm{W}(2.7,2.1)$ & $1.38 *(1 . /((1 . / U(0.5,0.5))-1)) * *.(1 . / 5.26)$ \\
\hline ALCT1 & BRSUAS & $1.35 *(1 . /((1 . / U(0.5,0.5))-1)) *.(1 . / 2.79)$ & $P 6(3.69,7.63 e+004,3.35 e+004)$ \\
\hline ALCT1 & BRSSAS & $(1 . / 1.5) *(-\operatorname{LN}(\mathrm{U}(0.5,0.5))) * *(-1 . / 1.36)$ & $1.46 *(1 . /((1 . / U(0.5,0.5))-1)) * *.(1 . / 7.08)$ \\
\hline ALCT1 & BRSPBS & $\mathrm{B}(0.578,1 ., 0,7.32)$ & $13.8 *(1 . /(1 .+\operatorname{EXP}(-(\mathrm{N}(0 ., 1)-2.98) / 1.51)))$. \\
\hline ALCT1 & BRSSZS & $\mathrm{L}(1.36,1.71)$ & IG(9.81, 3.13) \\
\hline ALCT2 & BRRIG & $L(2.36,2.59)$ & $B(5.21,7.55,0,2.98)$ \\
\hline ALCT2 & BRIBB & P5(2.5, 2.33) & $\operatorname{ER}(1.61,10)$ \\
\hline ALCT2 & BRSSZN & $\mathrm{L}(1.7,2.11)$ & $G(3.72,0.703)$ \\
\hline ALCT2 & BRSSA & $24.5 *(1 . /(1 .+\operatorname{EXP}(-(\mathrm{N}(0 ., 1)-2.01) / 0.794)))$. & $1.4^{*}(1 . /((1 . / U(0.5,0.5))-1)) *.(1 . / 4.73)$ \\
\hline ALCT2 & BRSUA & $1.37 *(1 . /((1 . / \mathrm{U}(0.5,0.5))-1)) *.(1 . / 3.15)$ & $B(3.15,4.3,0,3.92)$ \\
\hline ALCT2 & BRPEC & $G(5.4,0.393)$ & $1.46 *(1 . /((1 . / \mathrm{U}(0.5,0.5))-1)) * *.(1 . / 4.86)$ \\
\hline ALCT2 & BRBTP & $(1 . / 0.648) *(-\operatorname{LN}(U(0.5,0.5))) *(-1 . / 2.63)$ & $10.2 *(1 . /(1 .+\operatorname{EXP}(-(\mathrm{N}(0 ., 1)-0.952) / 1.1)))$. \\
\hline ALCT2 & BRSSZS & $0.795 *(1 . /((1 . / U(0.5,0.5))-1 .))^{* *}(1 . / 1.9)$ & $\mathrm{P} 6(35.4,4.32,0.28)$ \\
\hline ALCT3 & ARBUE & P5 $(3.35,2.38)$ & $\mathrm{L}(1.83,1.45)$ \\
\hline ALCT3 & ARZAE & $\mathrm{L}(2.28,1.66)$ & $8.64 *(1 . /(1 .+\operatorname{EXP}(-(\mathrm{N}(0 ., 1)-2.04) / 1.77)))$. \\
\hline ALCT3 & ARROS & P5(3.87, 7.39) & $\mathrm{P} 6(4.81,1.14 \mathrm{e}+003,596)$ \\
\hline ALCT3 & BRIOA & $P 6(7.54,3.45,0.637)$ & $P 5(3.13,6.25)$ \\
\hline ALCT3 & BRBTP & $(1 . / 0.701) *(-\operatorname{LN}(U(0.5,0.5)))^{* *}(-1 . / 4.52)$ & $\mathrm{T}(0,2.32,6.37)$ \\
\hline ALCT3 & BRSSZ & $\mathrm{L}(1.63,1.9)$ & $12.4^{*}(1 . /(1 .+\operatorname{EXP}(-(\mathrm{N}(0 ., 1)-2.1) / 1.58)))$. \\
\hline ALCT4 & BRSSZ & $\operatorname{IG}(1.4,1.56)$ & P5 $(4.29,8.43)$ \\
\hline ALCT4 & BREMB & $(1 . / 1.05) *(-\operatorname{LN}(U(0.5,0.5)))^{* *}(-1 . / 1.65)$ & $7.7 *(1 . /(1 .+\operatorname{EXP}(-(\mathrm{N}(0 ., 1)-0.956) / 1.42)))$. \\
\hline ALCT4 & BRRIO & $\mathrm{P} 5(4.65,7.23)$ & $\mathrm{P} 6(5.01,9.56,4.02)$ \\
\hline ALCT4 & BRVIX & P5 $(11.9,25.1)$ & $L(2.63,1.88)$ \\
\hline ALCT6 & BRPEC & $\mathrm{W}(2.77,2.31)$ & $I G(6.74,1.33)$ \\
\hline ALCT6 & BRVLC & $(1 . / 0.725) *(-\operatorname{LN}(U(0.5,0.5)))^{* *}(-1 . / 1.31)$ & $I G(7.77,3.82)$ \\
\hline ALCT6 & BRSLZ & $\mathrm{W}(2.73,3.54)$ & P5 $(4.79,7.1)$ \\
\hline
\end{tabular}




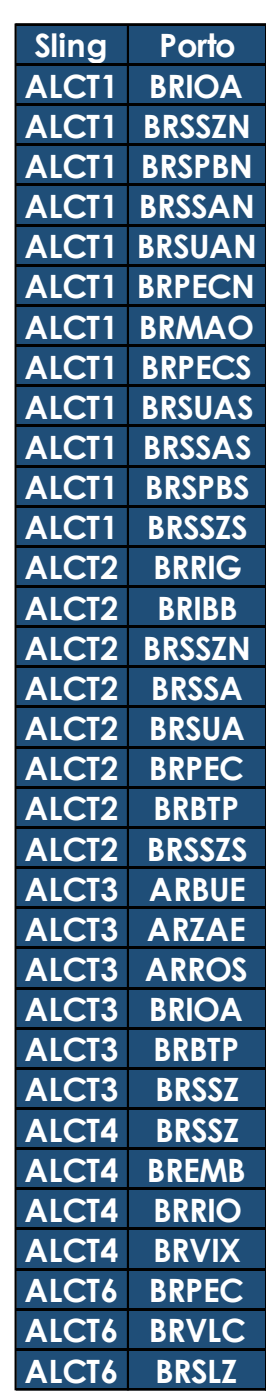

\begin{tabular}{|c|c|c|}
\hline Prod & Avg Crane & Hatch Cover \\
\hline$B(7.17,1.97,0,34.8)$ & $B(7.57,2.73,0,4.15)$ & $W(4.8,42.4)$ \\
\hline P5 $(34.3,829)$ & $W(5.85,2.72)$ & $-94.3+119 *(1 . /((1 . / U(0.5,0.5))-1)) *.(1 . / 37.2)$ \\
\hline$w(6.56,26.9)$ & $B(8.36,1.33,0,2.97)$ & $\mathrm{B}(3.88,5.92,0,22)$ \\
\hline $24.9 *(1 . /((1 . / U(0.5,0.5))-1 .))^{* *}(1 . / 14.5)$ & $B(5.58,1 ., 0,2.98)$ & $W(3.24,10.2)$ \\
\hline$W(7.17,25.6)$ & $B(7.84,1.88,0,3.02)$ & $\operatorname{ER}(9.41,16)$ \\
\hline$w(11.3,33.4)$ & $1.94-0.0273 * \operatorname{LN}((1 . / U(0.5,0.5))-1)$. & $\mathrm{N}(18.7,3)$ \\
\hline$L(13.8,2.61)$ & $B(29.4,2.19,0,3.03)$ & $\operatorname{IG}(860,69.2)$ \\
\hline$L(33.5,4.99)$ & $\mathrm{B}(20,1.74,0,2)$ & $L(11.2,6.86)$ \\
\hline $25.4^{*}(1 . /((1 . / U(0.5,0.5))-1 .))^{* *}(1 . / 12.1)$ & $G(33.8,0.0696)$ & $W(3.27,7.59)$ \\
\hline $24.3^{*}(1 . /((1 . / U(0.5,0.5))-1 .))^{* *}(1 . / 16.7)$ & $B(4.45,0.826,0,2.96)$ & $\mathrm{L}(11,4.33)$ \\
\hline $\operatorname{ER}(27.2,46)$ & $\mathrm{W}(7.38,2.64)$ & $\operatorname{IG}(51.3,7.85)$ \\
\hline$w(8.45,31.7)$ & $B(14.9,13.8,0,6.54)$ & $B(14.5,7.56,0,68)$ \\
\hline $37.9 *(1 . /(1 .+\operatorname{EXP}(-(N(0 ., 1)--0.973) / 1.67)))$. & P5 $(55.4,172)$ & $\mathrm{W}(4.57,37.1)$ \\
\hline $\mathrm{B}(11.8,4.41,0,44.5)$ & $W(67.2,1.97)$ & $W(4.6,36.6)$ \\
\hline P5(40.9, 1.07e+003) & $W(4.47,3.15)$ & $W(3.89,30.9)$ \\
\hline$W(9.09,27.9)$ & $B(10.9,0.979,0,2.97)$ & $123^{*}(1 . /(1 .+\operatorname{EXP}(-(\mathrm{N}(0 ., 1)-3.42) / 2)))$. \\
\hline$B(14.2,9.04,0,39.4)$ & $W(7.33,2.79)$ & $L(13.6,3.28)$ \\
\hline$W(8.31,34)$ & 2.0 & $35.7 *(1 . /((1 . / U(0.5,0.5))-1 .))^{* *}(1 . / 6.79)$ \\
\hline $34.6 *(1 . /((1 . / U(0.5,0.5))-1 .))^{* *}(1 . / 13.2)$ & $1.88 *(1 . /((1 . / U(0.5,0.5))-1 .))^{* *}(1 . / 5.93)$ & $\mathrm{P} 6(5.76,17.9,51)$ \\
\hline $\mathrm{W}(6.34,31.3)$ & $2.79 *(1 . /((1 . / U(0.5,0.5))-1 .))^{* *(1 . / 8.35)}$ & $\mathrm{P} 6(35.3,8.75,5.57)$ \\
\hline $21.3^{*}(1 . /((1 . / U(0.5,0.5))-1 .))^{* *}(1 . / 9.84)$ & $\mathrm{W}(3.68,1.56)$ & $G(10.6,0.868)$ \\
\hline $18.5^{*}(1 . /((1 . / U(0.5,0.5))-1 .))^{* *}(1 . / 11.1)$ & $W(21.9,1.92)$ & P5 $(22.9,676)$ \\
\hline$G(43.5,0.323)$ & $W(81.4,1.98)$ & P6 $(13.5,65.2,78)$ \\
\hline $\mathrm{W}(5.31,28.5)$ & $W(5.46,2.71)$ & $\mathrm{L}(17.5,4.58)$ \\
\hline$(1 . / 0.0332) *(-\operatorname{LN}(U(0.5,0.5))) *(-1 . / 9.66)$ & 1.0 & $\mathrm{~B}(1.48,1.0,12.7)$ \\
\hline $\mathrm{L}(25.6,4.68)$ & $2.85^{*}(1 . /((1 . / U(0.5,0.5))-1 .))^{* *}(1 . / 12.1)$ & $37.5^{*}(1 . /((1 . / \mathrm{U}(0.5,0.5))-1 .))^{* * *}(1 . / 8.15)$ \\
\hline$W(6.42,30.8)$ & $W(6.57,2.6)$ & $32.5+5.55 * \operatorname{LN}(\operatorname{LN}(1 . /(1 .-\mathrm{U}(0.5,0.5))))$ \\
\hline$P 5(31.4,1.14 e+003)$ & $B(5.58,1.47,0,2.13)$ & $\mathrm{W}(3.02,16.5)$ \\
\hline $\mathrm{B}(2.12,2.59,0,41.8)$ & 1.0 & $B(1.25,1.92,0,212)$ \\
\hline $17.8^{*}(1 . /((1 . / \mathrm{U}(0.5,0.5))-1 .))^{* *}(1 . / 11.8)$ & $(1 . / 0.481) *(-\operatorname{LN}(U(0.5,0.5))) * *(-1 . / 8.34)$ & $34.1^{*}(1 . /((1 . / U(0.5,0.5))-1 .))^{* *}(1 . / 11.3)$ \\
\hline $\operatorname{ER}(29.3,75)$ & $\mathrm{W}(47.2,1.92)$ & $\operatorname{ER}(23.2,3)$ \\
\hline$w(8.77,16.3)$ & $B(30.3,1.0,2)$ & IG $(71.7,21.4)$ \\
\hline$W(5.66,10.2)$ & 1.0 & $P 5(4.65,33.2)$ \\
\hline
\end{tabular}
Volume Q4 \begin{tabular}{|c|c|}
\hline & $B(3.71,1.33,0,1.19 \mathrm{e}+003)$ \\
\hline
\end{tabular} $B(5.37,2.13,0,869)$

$\mathrm{IG}(6.3 \mathrm{e}+003,712)$ $\mathrm{W}(5.25,706)$ P5 (13.9, 4.25e+003) \begin{tabular}{c|c}
$\mathrm{P}(13.9,4.25 \mathrm{e}+003)$ & $\mathrm{W}(4.18,326)$ \\
\hline $\mathrm{W}(8.95,757)$ & $(1 . / 0.00153)^{*}(-\operatorname{LN}(\mathrm{U}(0.5,0.5)))^{* *}(-1 . / 9.74)$ \\
\hline$(1 . / 0.00135)^{*}(-\operatorname{LN}(\mathrm{U}(0.5,0.5)))^{* * *}(-1 . / 6.68)$ & $786^{*}(1 . /((1 . / \mathrm{U}(0.5,0.5))-1 .))^{* * *}(1 . / 8.74)$
\end{tabular} $\mathrm{W}(4.18,326)$ \begin{tabular}{c|c}
$\mathrm{W}(8.95,757)$ & $(1 . / 0.00153)^{*}(-\operatorname{LN}(\mathrm{U}(0.5,0.5)))^{* * *}(-1 . / 9.74)$ \\
\hline$(1 . / 0.00135)^{*}(-\operatorname{LN}(\mathrm{U}(0.5,0.5)))^{* *}(-1 . / 6.68)$ & $786^{*}(1 . /((1 . / \mathrm{U}(0.5,0.5))-1 .))^{* *}(1 . / 8.74)$
\end{tabular} $\mathrm{B}(6.57,1.88,0,3.07 \mathrm{e}+003)$
$\left.(1 . / 0.00356)^{*}(-\operatorname{LN}(\mathrm{U}(0.5,0.5)))\right)^{* *}(-1 . / 3.7)$ P5 $(22.2,8.72 \mathrm{e}+003)$ IG(9.97e+004, 2.3e+003) P5 $(6.08,1.82 \mathrm{e}+003)$ \begin{tabular}{|c|c|}
$1.83 \mathrm{e}+003^{*}(1 . /(1 .+\mathrm{EXP}(-(\mathrm{N}(0 ., 1)-3.81) / 3.52)))$. \\
\hline $514^{*}(1 . /((1 . / \mathrm{U}(0.5,0.5))-1 .))^{* *}(1 . / 7.32)$
\end{tabular} $(1 . / 0.00248)^{*}(-\operatorname{LN}(\mathrm{U}(0.5,0.5)))^{* * *}(-1 . / 12.6)$ $\mathrm{IG}(5.03 \mathrm{e}+003,526)$

\begin{tabular}{c|c}
$(1 . / 0.00248)^{*}(-\operatorname{LN}(U(0.5,0.5)))^{* * *}(-1 . / 2.75)$ & $1 \mathrm{G}(5.03 \mathrm{e}+003,526)$ \\
\hline $\mathrm{P} 6(23.3,50.4,2.5 \mathrm{e}+003)$ & $1.12 \mathrm{e}+003^{*}(1 . /((1 . / \mathrm{U}(0.5,0.5))-1.1))^{* *}(1 . / 10.3)$ \\
\hline
\end{tabular} P6(21.5, 43.8, 1.67e+003) P5 (38.5, 3.15e+004) $T(0,973,1.53 \mathrm{e}+003)$ $\frac{\mathrm{W}(4.6,857)}{(1 . / 0.00117)^{*}(-\operatorname{LN}(\mathrm{U}(0.5,0.5)))^{* *}(-1 . / 7.49)}$ (- $W(4(4,0.5,0.5))$ $B(3.85,1.72,0,941)$ $\mathrm{G}(13.6,45.6)$ $\mathrm{W}(6.41,992)$ $\mathrm{W}(8.85,1.42 \mathrm{e}+003)$ $\mathrm{W}(3.02,605)$ P5 $(6.69,3.9 \mathrm{e}+003)$ IG(3.26e+003, 294) $\mathrm{W}(8.29,1.31 \mathrm{e}+003)$ $\mathrm{G}(22.9,32.1)$ $\mathrm{W}(5.11,766)$ $\mathrm{G}(3.59,53.6)$ $\mathrm{W}(7.7,1.45 \mathrm{e}+003)$ $\mathrm{L}(900,117)$ $\frac{\mathrm{W}(3.02,500)}{216^{*}(1 . /(1++\operatorname{EXP}(-(\mathrm{N}(0.1 .1)--0.0826) / 0.578)))}$ $\frac{1}{((1 . / U(0.5,0.5))-1 .))^{* * *}(1 . / 12.8)}$ P6 $(134,136,1.37 \mathrm{e}+003)$ $\mathrm{W}(2.95,501)$ $(1 . / 0.00195)^{*}(-\operatorname{LN}(U(0.5,0.5))) * *(-1 / 13.43)$ IG(3.26e+003, 294) $\mathrm{L}(1.11 \mathrm{e}+003,121)$ $\mathrm{L}(475,91.4)$ $\mathrm{W}(5.52,582)$ $\mathrm{G}(3.59,53.6)$

$(1 . / 0.000924)^{*}(-\operatorname{LN}(U(0.5,0.5)))^{* *}(-1 . / 8.96)$ $\mathrm{W}(6.51,845)$ $\frac{W(6.51,845)}{\mathrm{W}(3.02,500)}$ \begin{tabular}{c|c}
$\mathrm{W}(11.5,1.46 \mathrm{e}+003)$ & $\mathrm{P} 5(47.4,6.01 \mathrm{e}+004)$ \\
\hline
\end{tabular} $B(3.73,6.28,293,917)$ $(1 . / 0.0022) *(-\operatorname{LN}(U(0.5,0.5))) * *(-1 . / 5.48)$ $\mathrm{P} 5(18.6,8.9 \mathrm{e}+003)$ $\mathrm{W}(5.87,543)$ $\mathrm{W}(2.4,157)$ $\mathrm{W}(2.4,157)$ 


\section{APÊNDICE D - MODELO PROMODEL}

Layout do modelo, demonstrando os locais (portos e barras) e redes de caminhos (roteirização de cada anel).

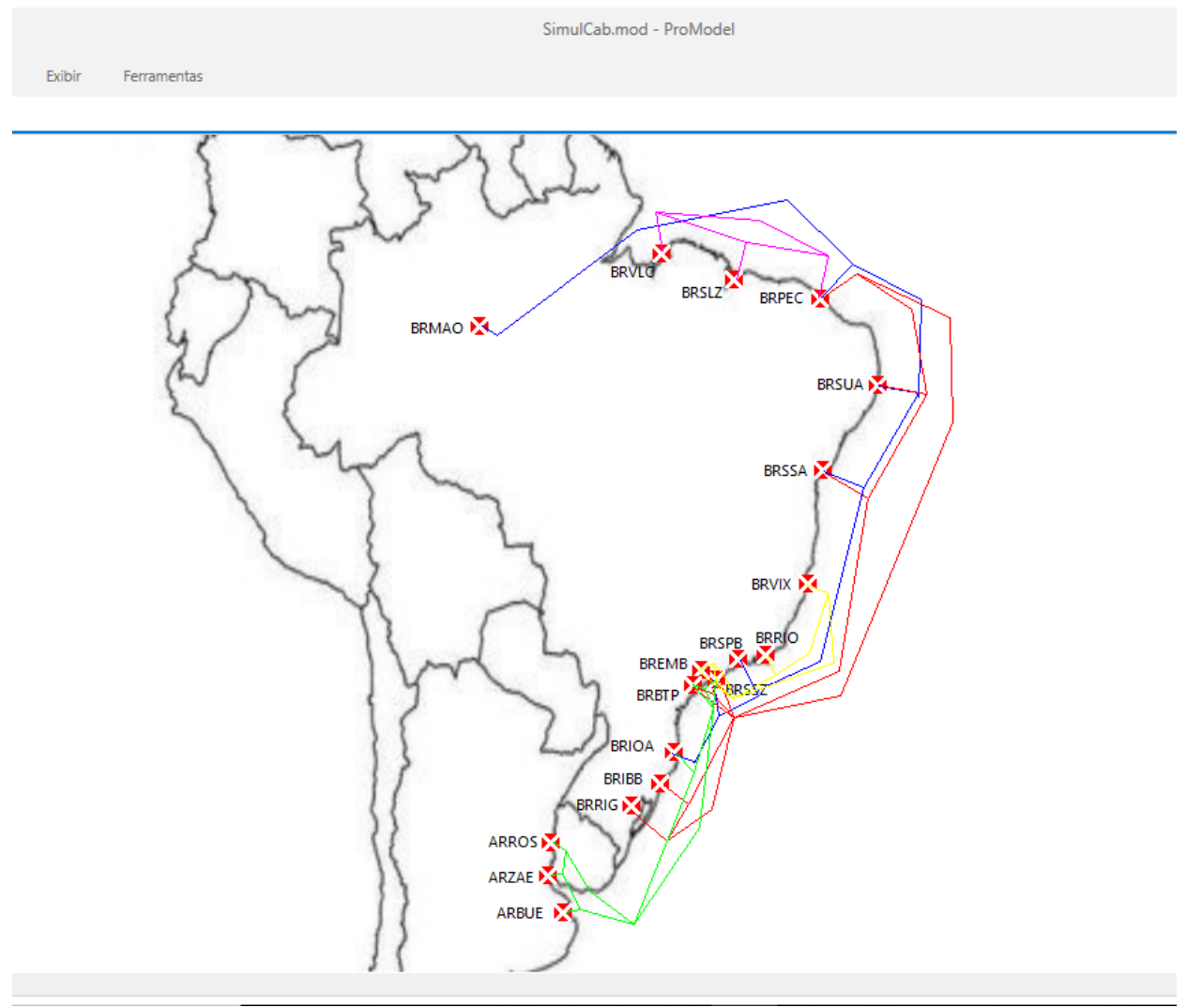

Entidades do modelo (navios)

\begin{tabular}{|l|l|l|l|}
\hline & \\
\hline
\end{tabular}




\section{APÊNDICE E - LÓGICA COMPUTACIONAL}

Lógica utilizada no Anel 1, mais completo. Os demais anéis foram modelados de maneira análoga.

-- OP BIOA --

MoveAMVES $=$ MoveAMVES +1

If ArrivAMVES $=1$ Then

\{

ArrivAMVES $=0$

Route 1

\}

Else

\{

VoyAMVES $=$ VoyAMVES +1

DirAMVES $=1$

SVDistAMVES $=0$

RVDistAMVES $=0$

SVConsAMVES $=0$

RVConsAMVES $=0$

VolIOA1 $=$ tbVolumes[1,Trunc $(\operatorname{Clock}(\mathrm{hr}) / 2190)+2]$

HCIOA $1=$ tbVolumes $[1,1]$

If JanIOA $1=2$ Then

\{

Route 1

OmitIOA $1=$ OmitIOA $1+1$

\}

Else

\{

If JanIOA $1=0$ Then Wait Until JanIOA $1=1$

Route 2

\} 
-- PARA BSSZ --

move for tbRotas[2,1]

DistAMVES $=$ tbRotas[2,2]

ConsAMVES $=$ tbRotas[2,4]

SVDistAMVES $=$ SVDistAMVES + DistAMVES

RVDistAMVES = RVDistAMVES + DistAMVES

SVConsAMVES $=$ SVConsAMVES + ConsAMVES

RVConsAMVES $=$ RVConsAMVES + ConsAMVES

-- PARA BRIOA --

move for tbRotas[1,1]

ConsAMVES $=$ tbRotas $[1,4]$

SVConsAMVES = SVConsAMVES + ConsAMVES

RVConsAMVES = RVConsAMVES + ConsAMVES

-- OP BRIOA --

MoveAMVES $=$ MoveAMVES +1

WaitPreIOA $1=$ tbTempos $[1,1]$

WaitPosIOA $1=$ tbTempos $[1,4]$

ProdIOA1 $=$ tbTempos $[1,2]$

AvgCraneIOA $1=$ tbTempos[1,3]

OpTimeIOA $1=($ VolIOA $1+$ HCIOA 1$) /($ ProdIOA $1 *$ AvgCraneIOA 1$)$

TtlTimeIOA1 = WaitPreIOA1 + OpTimeIOA1 + WaitPosIOA1

Wait TtlTimeIOA1

SVConsAMVES $=$ SVConsAMVES + Tt1TimeIOA1 * $($ PConsAMVES/24)

RVConsAMVES $=$ RVConsAMVES + Tt1TimeIOA1 * (PConsAMVES/24)

ArrivAMVES = 1 
-- PARA BIOA --

move for tbRotas[1,1]

ConsAMVES $=$ tbRotas $[1,4]$

SVConsAMVES $=$ SVConsAMVES + ConsAMVES

RVConsAMVES $=$ RVConsAMVES + ConsAMVES

\section{-- OP BSSZ --}

MoveAMVES $=$ MoveAMVES +1

If DirAMVES $=1$ Then

\{

If ArrivAMVES $=1$ Then

\{

ArrivAMVES $=0$

Route 1

\}

Else

\{

VolSSZN1 $=$ tbVolumes[2,Trunc $(\operatorname{Clock}(\mathrm{hr}) / 2190)+2]$

HCSSZN1 $=$ tbVolumes[2,1]

If JanSSZN1 $=2$ Then

\{

Route 1

OmitSSZ1N $=$ OmitSSZ1N +1

\}

Else

\{

If JanSSZN1 $=0$ Then Wait Until JanSSZN1 $=1$

Route 2 
Else

\{

If ArrivAMVES $=1$ Then

\{

ArrivAMVES $=0$

Route 3

\}

Else

\{

VolSSZS1 = tbVolumes[12, Trunc $(\operatorname{Clock}(\mathrm{hr}) / 2190)+2]$

HCSSZS1 $=$ tbVolumes[12,1]

If JanSSZS1 $=2$ Then

\{

Route 3

OmitSSZ1S $=$ OmitSSZ1S +1

\}

Else

\{

If JanSSZS $1=0$ Then Wait Until JanSSZS1 $=1$

Route 4

\}

\}

\}

-- PARA BSPB --

move for tbRotas[4,1]

DistAMVES $=$ tbRotas[4,2]

ConsAMVES $=$ tbRotas $[4,4]$

SVDistAMVES $=$ SVDistAMVES + DistAMVES 
RVDistAMVES $=$ RVDistAMVES + DistAMVES

SVConsAMVES $=$ SVConsAMVES + ConsAMVES

RVConsAMVES $=$ RVConsAMVES + ConsAMVES

-- PARA BRSSZ --

Move For tbRotas[3,1]

ConsAMVES $=$ tbRotas $[3,4]$

SVConsAMVES $=$ SVConsAMVES + ConsAMVES

RVConsAMVES = RVConsAMVES + ConsAMVES

-- PARA BIOA --

move for tbRotas[26,1]

DistAMVES $=$ tbRotas $[26,2]$

ConsAMVES $=$ tbRotas $[26,4]$

SVDistAMVES $=$ SVDistAMVES + DistAMVES

RVDistAMVES $=$ RVDistAMVES + DistAMVES

SVConsAMVES $=$ SVConsAMVES + ConsAMVES

RVConsAMVES $=$ RVConsAMVES + ConsAMVES

-- PARA BRSSZ --

Move For tbRotas[25,1]

ConsAMVES $=$ tbRotas $[25,4]$

SVConsAMVES $=$ SVConsAMVES + ConsAMVES

RVConsAMVES $=$ RVConsAMVES + ConsAMVES 
-- OP BRSSZ --

MoveAMVES $=$ MoveAMVES + 1

ArrivAMVES $=1$

If DirAMVES $=1$ Then

\{

WaitPreSSZN1 = tbTempos[2,1]

WaitPosSSZN1 = tbTempos[2,4]

ProdSSZN1 $=\mathrm{tb}$ Tempos[2,2]

AvgCraneSSZN1 = tbTempos[2,3]

OpTimeSSZN1 $=($ VolSSZN1 + HCSSZN1 $) /($ ProdSSZN1 $*$ AvgCraneSSZN1 $)$

Tt1TimeSSZN1 = WaitPreSSZN1 + OpTimeSSZN1 + WaitPosSSZN1

Wait TtlTimeSSZN1

SVConsAMVES $=$ SVConsAMVES + TttTimeSSZN1 * (PConsAMVES/24)

RVConsAMVES = RVConsAMVES + TtlTimeSSZN1 * (PConsAMVES/24)

Route 1

\}

Else

\{

WaitPreSSZS1 $=$ tbTempos[12,1]

WaitPosSSZS1 = tbTempos[12,4]

ProdSSZS1 $=$ tbTempos[12,2]

AvgCraneSSZS1 $=$ tbTempos[12,3]

OpTimeSSZS1 $=($ VolSSZS1 + HCSSZS1 $) /($ ProdSSZS1 * AvgCraneSSZS1 $)$

Tt1TimeSSZS1 = WaitPreSSZS1 + OpTimeSSZS1 + WaitPosSSZS1

Wait TtlTimeSSZS1

SVConsAMVES $=$ SVConsAMVES + TttTimeSSZS $1 *($ PConsAMVES/24)

RVConsAMVES = RVConsAMVES + Tt1TimeSSZS1 * (PConsAMVES/24)

Route 2 
Move For tbRotas[3,1]

ConsAMVES $=$ tbRotas[3,4]

SVConsAMVES $=$ SVConsAMVES + ConsAMVES

RVConsAMVES $=$ RVConsAMVES + ConsAMVES

-- PARA BSSZ --

Move For tbRotas[25,1]

ConsAMVES $=$ tbRotas $[25,4]$

SVConsAMVES $=$ SVConsAMVES + ConsAMVES

RVConsAMVES $=$ RVConsAMVES + ConsAMVES

-- OP BSPB --

MoveAMVES $=$ MoveAMVES +1

If DirAMVES $=1$ Then

\{

If ArrivAMVES $=1$ Then

\{

ArrivAMVES $=0$

Route 1

\}

Else

\{

VolSPBN1 $=$ tbVolumes[3,Trunc $(\operatorname{Clock}(\mathrm{hr}) / 2190)+2]$

HCSPBN1 = tbVolumes[3,1]

If JanSPBN1 $=2$ Then

\{

Route 1

OmitSPB1N $=$ OmitSPB1N +1 
Else

\{

If JanSPBN1 $=0$ Then Wait Until JanSPBN1 $=1$

Route 2

\}

\}

\}

Else

\{

If ArrivAMVES $=1$ Then

\{

ArrivAMVES $=0$

Route 3

\}

Else

\{

VolSPBS1 = tbVolumes[11,Trunc $(\operatorname{Clock}(\mathrm{hr}) / 2190)+2]$

HCSPBS1 $=$ tbVolumes[11,1]

If JanSPBS1 $=2$ Then

\{

Route 3

OmitSPB1S = OmitSPB1S +1

\}

Else

\{

If JanSPBS $1=0$ Then Wait Until JanSPBS1 $=1$

Route 4

\}

\}

\} 
move for tbRotas[6,1]

DistAMVES $=$ tbRotas [6,2]

ConsAMVES $=$ tbRotas[6,4]

SVDistAMVES $=$ SVDistAMVES + DistAMVES

RVDistAMVES $=$ RVDistAMVES + DistAMVES

SVConsAMVES $=$ SVConsAMVES + ConsAMVES

RVConsAMVES $=$ RVConsAMVES + ConsAMVES

-- PARA BRSPB --

Move For tbRotas[5,1]

ConsAMVES $=$ tbRotas $[5,4]$

SVConsAMVES $=$ SVConsAMVES + ConsAMVES

RVConsAMVES $=$ RVConsAMVES + ConsAMVES

-- PARA BSSZ --

move for tbRotas[24,1]

DistAMVES $=$ tbRotas[24,2]

ConsAMVES $=$ tbRotas[24,4]

SVDistAMVES $=$ SVDistAMVES + DistAMVES

RVDistAMVES $=$ RVDistAMVES + DistAMVES

SVConsAMVES $=$ SVConsAMVES + ConsAMVES

RVConsAMVES $=$ RVConsAMVES + ConsAMVES

-- PARA BRSPB --

Move For tbRotas[23,1]

ConsAMVES $=$ tbRotas $[23,4]$

SVConsAMVES $=$ SVConsAMVES + ConsAMVES 
RVConsAMVES $=$ RVConsAMVES + ConsAMVES

-- OP BRSPB --

MoveAMVES $=$ MoveAMVES +1

ArrivAMVES $=1$

If DirAMVES $=1$ Then

\{

WaitPreSPBN1 $=$ tbTempos[3,1]

WaitPosSPBN1 $=$ tbTempos[3,4]

ProdSPBN1 $=$ tbTempos[3,2]

AvgCraneSPBN1 = tbTempos[3,3]

OpTimeSPBN1 $=($ VolSPBN1 + HCSPBN1 $) /($ ProdSPBN1 * AvgCraneSPBN1 $)$

TtlTimeSPBN1 = WaitPreSPBN1 + OpTimeSPBN1 + WaitPosSPBN1

Wait TtlTimeSPBN1

SVConsAMVES = SVConsAMVES + Tt1TimeSPBN1 * (PConsAMVES/24)

RVConsAMVES = RVConsAMVES + TttTimeSPBN1 * (PConsAMVES/24)

Route 1

\}

Else

\{

WaitPreSPBS $1=$ tbTempos[11,1]

WaitPosSPBS1 $=$ tbTempos $[11,4]$

ProdSPBS1 $=$ tbTempos[11,2]

AvgCraneSPBS $1=$ tbTempos[11,3]

OpTimeSPBS $1=($ VolSPBS1 + HCSPBS1 $) /($ ProdSPBS1 $*$ AvgCraneSPBS 1$)$

Tt1TimeSPBS1 = WaitPreSPBS1 + OpTimeSPBS1 + WaitPosSPBS1

Wait TttTimeSPBS1

SVConsAMVES $=$ SVConsAMVES + TtlTimeSPBS1 * $($ PConsAMVES/24)

RVConsAMVES = RVConsAMVES + TtlTimeSPBS1 * (PConsAMVES/24)

Route 2 
-- PARA BSPB --

Move For tbRotas[5,1]

ConsAMVES $=$ tbRotas $[5,4]$

SVConsAMVES $=$ SVConsAMVES + ConsAMVES

RVConsAMVES $=$ RVConsAMVES + ConsAMVES

-- PARA BSPB --

Move For tbRotas[23,1]

ConsAMVES $=$ tbRotas $[23,4]$

SVConsAMVES $=$ SVConsAMVES + ConsAMVES

RVConsAMVES $=$ RVConsAMVES + ConsAMVES

-- OP BSSA --

MoveAMVES $=$ MoveAMVES +1

If DirAMVES $=1$ Then

\{

If ArrivAMVES $=1$ Then

\{

ArrivAMVES $=0$

Route 1

\}

Else

\{

VolSSAN1 $=$ tbVolumes[4,Trunc $(\operatorname{Clock}(\mathrm{hr}) / 2190)+2]$

HCSSAN1 = tbVolumes[4,1] 
If JanSSAN1 $=2$ Then

\{

Route 1

OmitSSA1N $=$ OmitSSA1N +1

\}

Else

\{

If JanSSAN $1=0$ Then Wait Until JanSSAN1 $=1$

Route 2

\}

\}

\}

Else

\{

If ArrivAMVES $=1$ Then

\{

ArrivAMVES $=0$

Route 3

\}

Else

\{

VolSSAS1 $=$ tbVolumes[10,Trunc $(\operatorname{Clock}(\mathrm{hr}) / 2190)+2]$

HCSSAS1 $=$ tbVolumes $[10,1]$

If JanSSAS $1=2$ Then

\{

Route 3

OmitSSA1S $=$ OmitSSA1S +1

\}

Else

\{

If JanSSAS $1=0$ Then Wait Until JanSSAS $1=1$

Route 4 
-- PARA BSUA --

move for tbRotas[8,1]

DistAMVES $=$ tbRotas $[8,2]$

ConsAMVES $=$ tbRotas $[8,4]$

SVDistAMVES $=$ SVDistAMVES + DistAMVES

RVDistAMVES $=$ RVDistAMVES + DistAMVES

SVConsAMVES $=$ SVConsAMVES + ConsAMVES

RVConsAMVES = RVConsAMVES + ConsAMVES

-- PARA BRSSA --

Move For tbRotas[7,1]

ConsAMVES $=$ tbRotas $[7,4]$

SVConsAMVES = SVConsAMVES + ConsAMVES

RVConsAMVES = RVConsAMVES + ConsAMVES

-- PARA BSPB --

move for tbRotas[22,1]

DistAMVES $=$ tbRotas[22,2]

ConsAMVES $=$ tbRotas[22,4]

SVDistAMVES $=$ SVDistAMVES + DistAMVES

RVDistAMVES $=$ RVDistAMVES + DistAMVES

SVConsAMVES $=$ SVConsAMVES + ConsAMVES

RVConsAMVES = RVConsAMVES + ConsAMVES 
-- PARA BRSSA --

Move For tbRotas[21,1]

ConsAMVES $=$ tbRotas $[21,4]$

SVConsAMVES $=$ SVConsAMVES + ConsAMVES

RVConsAMVES $=$ RVConsAMVES + ConsAMVES

-- OP BRSSA --

MoveAMVES $=$ MoveAMVES +1

ArrivAMVES $=1$

If DirAMVES $=1$ Then

\{

WaitPreSSAN1 = tbTempos[4,1]

WaitPosSSAN1 = tbTempos[4,4]

ProdSSAN1 $=$ tbTempos[4,2]

AvgCraneSSAN1 $=$ tbTempos[4,3]

OpTimeSSAN1 $=($ VolSSAN1 + HCSSAN1 $) /($ ProdSSAN1 $*$ AvgCraneSSAN1 $)$

TtlTimeSSAN1 = WaitPreSSAN1 + OpTimeSSAN1 + WaitPosSSAN1

Wait TtlTimeSSAN1

SVConsAMVES $=$ SVConsAMVES + TtlTimeSSAN1 * (PConsAMVES/24)

RVConsAMVES = RVConsAMVES + TtlTimeSSAN1 * (PConsAMVES/24)

Route 1

\}

Else

\{

WaitPreSSAS1 $=$ tbTempos[10,1]

WaitPosSSAS1 $=$ tbTempos[10,4]

ProdSSAS $1=$ tbTempos[10,2]

AvgCraneSSAS1 $=$ tbTempos[10,3]

OpTimeSSAS $1=($ VolSSAS1 + HCSSAS 1$) /($ ProdSSAS $1 *$ AvgCraneSSAS 1$)$ 
TtlTimeSSAS1 $=$ WaitPreSSAS1 + OpTimeSSAS1 + WaitPosSSAS1

Wait Tt1TimeSSAS1

SVConsAMVES $=$ SVConsAMVES + TtlTimeSSAS1 $*($ PConsAMVES/24)

RVConsAMVES $=$ RVConsAMVES + Tt1TimeSSAS1 $*($ PConsAMVES $/ 24)$

Route 2

\}

-- PARA BSSA --

Move For tbRotas[7,1]

ConsAMVES $=$ tbRotas $[7,4]$

SVConsAMVES $=$ SVConsAMVES + ConsAMVES

RVConsAMVES $=$ RVConsAMVES + ConsAMVES

-- PARA BSSA --

Move For tbRotas[21,1]

ConsAMVES $=$ tbRotas $[21,4]$

SVConsAMVES $=$ SVConsAMVES + ConsAMVES

RVConsAMVES $=$ RVConsAMVES + ConsAMVES

-- OP BSUA --

MoveAMVES $=$ MoveAMVES +1

If DirAMVES $=1$ Then

\{

If ArrivAMVES $=1$ Then

\{

ArrivAMVES $=0$ 


\section{Route 1}

\}

Else

\{

VolSUAN1 $=$ tbVolumes[5,Trunc $(\operatorname{Clock}(\mathrm{hr}) / 2190)+2]$

HCSUAN1 $=$ tbVolumes[5,1]

If JanSUAN1 $=2$ Then

\{

Route 1

OmitSUA1N $=$ OmitSUA1N +1

\}

Else

\{

If JanSUAN $1=0$ Then Wait Until JanSUAN1 $=1$

Route 2

\}

\}

\}

Else

\{

If ArrivAMVES $=1$ Then

\{

ArrivAMVES $=0$

Route 3

\}

Else

\{

VolSUAS1 $=$ tbVolumes[9,Trunc $(\operatorname{Clock}(\mathrm{hr}) / 2190)+2]$

HCSUAS $1=$ tbVolumes[9,1]

If JanSUAS $1=2$ Then

\{

Route 3

OmitSUA1S $=$ OmitSUA1S +1 
Else

\{

If JanSUAS $1=0$ Then Wait Until JanSUAS $1=1$

Route 4

\}

\}

\}

-- PARA BPEC --

move for tbRotas[10,1]

DistAMVES $=$ tbRotas[10,2]

ConsAMVES $=$ tbRotas $[10,4]$

SVDistAMVES $=$ SVDistAMVES + DistAMVES

RVDistAMVES $=$ RVDistAMVES + DistAMVES

SVConsAMVES $=$ SVConsAMVES + ConsAMVES

RVConsAMVES $=$ RVConsAMVES + ConsAMVES

-- PARA BRSUA --

Move For tbRotas[9,1]

ConsAMVES $=$ tbRotas[9,4]

SVConsAMVES $=$ SVConsAMVES + ConsAMVES

RVConsAMVES = RVConsAMVES + ConsAMVES

-- PARA BSSA --

move for tbRotas[20,1]

DistAMVES $=$ tbRotas[20,2]

ConsAMVES $=$ tbRotas $[20,4]$ 
SVDistAMVES $=$ SVDistAMVES + DistAMVES
RVDistAMVES $=$ RVDistAMVES + DistAMVES
SVConsAMVES $=$ SVConsAMVES + ConsAMVES
RVConsAMVES $=$ RVConsAMVES + ConsAMVES

-- PARA BRSUA --

Move For tbRotas[19,1]

ConsAMVES $=$ tbRotas $[19,4]$

SVConsAMVES $=$ SVConsAMVES + ConsAMVES

RVConsAMVES $=$ RVConsAMVES + ConsAMVES

-- OP BRSUA --

MoveAMVES $=$ MoveAMVES +1

ArrivAMVES $=1$

If DirAMVES $=1$ Then

\{

WaitPreSUAN1 $=$ tbTempos[5,1]

WaitPosSUAN1 $=$ tbTempos[5,4]

ProdSUAN1 $=$ tbTempos[5,2]

AvgCraneSUAN1 $=$ tbTempos[5,3]

OpTimeSUAN1 $=($ VolSUAN1 + HCSUAN1) $/($ ProdSUAN1 $*$ AvgCraneSUAN1 $)$

TtlTimeSUAN1 = WaitPreSUAN1 + OpTimeSUAN1 + WaitPosSUAN1

Wait TtlTimeSUAN1

SVConsAMVES $=$ SVConsAMVES + TtlTimeSUAN1 $*($ PConsAMVES/24)

RVConsAMVES = RVConsAMVES + TtlTimeSUAN1 * (PConsAMVES/24)

Route 1

\}

Else 
WaitPreSUAS $1=$ tbTempos[9,1]

WaitPosSUAS $1=$ tbTempos[9,4]

ProdSUAS1 $=$ tbTempos[9,2]

AvgCraneSUAS1 $=$ tbTempos[9,3]

OpTimeSUAS1 $=($ VolSUAS1 + HCSUAS 1$) /($ ProdSUAS1 $*$ AvgCraneSUAS1 $)$

Tt1TimeSUAS1 = WaitPreSUAS1 + OpTimeSUAS1 + WaitPosSUAS1

Wait TtlTimeSUAS1

SVConsAMVES $=$ SVConsAMVES + TtlTimeSUAS1 $*($ PConsAMVES/24)

RVConsAMVES = RVConsAMVES + TttTimeSUAS1 * (PConsAMVES/24)

Route 2

\}

-- PARA BSUA --

Move For tbRotas[9,1]

ConsAMVES $=$ tbRotas[9,4]

SVConsAMVES $=$ SVConsAMVES + ConsAMVES

RVConsAMVES $=$ RVConsAMVES + ConsAMVES

-- PARA BSUA --

Move For tbRotas[19,1]

ConsAMVES $=$ tbRotas $[19,4]$

SVConsAMVES $=$ SVConsAMVES + ConsAMVES

RVConsAMVES $=$ RVConsAMVES + ConsAMVES

-- OP BPEC --

MoveAMVES $=$ MoveAMVES +1 
If DirAMVES $=1$ Then

\{

If ArrivAMVES $=1$ Then

\{

ArrivAMVES $=0$

Route 1

\}

Else

\{

VolPECN1 $=$ tbVolumes[6,Trunc $(\operatorname{Clock}(\mathrm{hr}) / 2190)+2]$

HCPECN1 = tbVolumes[6,1]

If JanPECN1 $=2$ Then

\{

Route 1

OmitPEC1N $=$ OmitPEC1N +1

\}

Else

\{

If JanPECN1 $=0$ Then Wait Until JanPECN1 $=1$

Route 2

\}

\}

\}

Else

\{

If ArrivAMVES $=1$ Then

\{

ArrivAMVES $=0$

Route 3

\}

Else

\{

VolPECS1 $=$ tbVolumes[8,Trunc $(\operatorname{Clock}(\mathrm{hr}) / 2190)+2]$

HCPECS $1=$ tbVolumes $[8,1]$ 
If JanPECS1 $=2$ Then

\{

Route 3

OmitPEC1S $=$ OmitPEC1S +1

\}

Else

\{

If JanPECS $1=0$ Then Wait Until JanPECS $1=1$

Route 4

\}

\}

-- PARA MCP --

move for tbRotas[12,1]

DistAMVES $=$ tbRotas[12,2]

ConsAMVES $=$ tbRotas $[12,4]$

SVDistAMVES $=$ SVDistAMVES + DistAMVES

RVDistAMVES $=$ RVDistAMVES + DistAMVES

SVConsAMVES $=$ SVConsAMVES + ConsAMVES

RVConsAMVES $=$ RVConsAMVES + ConsAMVES

-- PARA BRPEC --

Move For tbRotas[11,1]

ConsAMVES $=$ tbRotas[11,4]

SVConsAMVES $=$ SVConsAMVES + ConsAMVES

RVConsAMVES $=$ RVConsAMVES + ConsAMVES 
-- PARA BSUA --

move for tbRotas[18,1]

DistAMVES $=$ tbRotas[18,2]

ConsAMVES $=$ tbRotas[18,4]

SVDistAMVES $=$ SVDistAMVES + DistAMVES

RVDistAMVES $=$ RVDistAMVES + DistAMVES

SVConsAMVES $=$ SVConsAMVES + ConsAMVES

RVConsAMVES $=$ RVConsAMVES + ConsAMVES

-- PARA BRPEC --

Move For tbRotas[17,1]

ConsAMVES $=\operatorname{tb} \operatorname{Rotas}[17,4]$

SVConsAMVES $=$ SVConsAMVES + ConsAMVES

RVConsAMVES $=$ RVConsAMVES + ConsAMVES

\section{-- OP BRPEC --}

MoveAMVES $=$ MoveAMVES +1

ArrivAMVES $=1$

If DirAMVES $=1$ Then

\{

WaitPrePECN1 $=$ tbTempos[6,1]

WaitPosPECN1 = tbTempos[6,4]

ProdPECN1 $=$ tbTempos[6,2]

AvgCranePECN1 = tbTempos[6,3]

OpTimePECN1 $=($ VolPECN1 + HCPECN1 $) /($ ProdPECN1 * AvgCranePECN1 $)$

TtlTimePECN1 = WaitPrePECN1 + OpTimePECN1 + WaitPosPECN1

Wait TtlTimePECN1

SVConsAMVES $=$ SVConsAMVES + TtlTimePECN1 * (PConsAMVES/24) 
RVConsAMVES = RVConsAMVES + TtlTimePECN1 * (PConsAMVES/24)

Route 1

\}

Else

\{

WaitPrePECS1 $=$ tbTempos $[8,1]$

WaitPosPECS1 $=$ tbTempos[8,4]

ProdPECS1 $=$ tbTempos[8,2]

AvgCranePECS1 $=$ tbTempos[8,3]

OpTimePECS $1=($ VolPECS $1+$ HCPECS 1$) /($ ProdPECS $1 *$ AvgCranePECS 1$)$

TtlTimePECS1 = WaitPrePECS1 + OpTimePECS1 + WaitPosPECS1

Wait TtlTimePECS1

SVConsAMVES $=$ SVConsAMVES + TtlTimePECS $1 *($ PConsAMVES/24)

RVConsAMVES = RVConsAMVES + TtlTimePECS1 * (PConsAMVES/24)

Route 2

\}

-- PARA BPEC --

Move For tbRotas[11,1]

ConsAMVES $=$ tbRotas $[11,4]$

SVConsAMVES $=$ SVConsAMVES + ConsAMVES

RVConsAMVES $=$ RVConsAMVES + ConsAMVES

-- PARA BPEC --

Move For tbRotas[17,1]

ConsAMVES $=$ tbRotas $[17,4]$

SVConsAMVES $=$ SVConsAMVES + ConsAMVES

RVConsAMVES $=$ RVConsAMVES + ConsAMVES 
-- OP MCP --

MoveAMVES $=$ MoveAMVES +1

If DirAMVES $=1$ Then

\{

Wait 1

Route 1

\}

Else

\{

Wait 1

Route 2

\}

-- PARA BMAO --

move for tbRotas[13,1]

DistAMVES $=$ tbRotas $[13,2]$

ConsAMVES $=$ tbRotas $[13,4]$

SVDistAMVES $=$ SVDistAMVES + DistAMVES

RVDistAMVES $=$ RVDistAMVES + DistAMVES

SVConsAMVES $=$ SVConsAMVES + ConsAMVES

RVConsAMVES $=$ RVConsAMVES + ConsAMVES

-- PARA BPEC --

move for tbRotas[16,1]

DistAMVES $=$ tbRotas $[16,2]$

ConsAMVES $=$ tbRotas $[16,4]$

SVDistAMVES $=$ SVDistAMVES + DistAMVES

RVDistAMVES $=$ RVDistAMVES + DistAMVES

SVConsAMVES $=$ SVConsAMVES + ConsAMVES 
RVConsAMVES $=$ RVConsAMVES + ConsAMVES

-- OP BMAO --

MoveAMVES $=$ MoveAMVES +1

If ArrivAMVES $=1$ Then

\{

ArrivAMVES $=0$

Route 1

\}

Else

\{

DirAMVES $=2$

SVDistAMVES $=0$

SVConsAMVES $=0$

VolMAO1 $=$ tbVolumes[7,Trunc $($ Clock(hr)/2190)+2]

HCMAO1 $=$ tbVolumes[7,1]

If JanMAO1 $=2$ Then

\{

OutWindMAO1 $=$ OutWindMAO $1+1$

\}

Else

\{

If JanMAO1 $=0$ Then Wait Until JanMAO1 $=1$

\}

Route 2

\}

-- PARA MCP --

move for tbRotas[15,1]

DistAMVES $=$ tbRotas $[15,2]$

ConsAMVES $=$ tbRotas $[15,4]$ 
SVDistAMVES $=$ SVDistAMVES + DistAMVES
RVDistAMVES $=$ RVDistAMVES + DistAMVES
SVConsAMVES $=$ SVConsAMVES + ConsAMVES
RVConsAMVES $=$ RVConsAMVES + ConsAMVES

-- PARA BRMAO --

Move For tbRotas[14,1]

ConsAMVES $=$ tbRotas $[14,4]$

SVConsAMVES $=$ SVConsAMVES + ConsAMVES

RVConsAMVES $=$ RVConsAMVES + ConsAMVES

-- OP BRMAO --

MoveAMVES $=$ MoveAMVES +1

WaitPreMAO1 $=$ tbTempos[7,1]

WaitPosMAO1 $=$ tbTempos[7,4]

ProdMAO1 $=$ tbTempos[7,2]

AvgCraneMAO1 $=$ tbTempos[7,3]

OpTimeMAO1 $=($ VolMAO1 + HCMAO1 $) /($ ProdMAO1 $*$ AvgCraneMAO1 $)$

TtlTimeMAO1 $=$ WaitPreMAO1 + OpTimeMAO1 + WaitPosMAO1

Wait TtlTimeMAO1

SVConsAMVES $=$ SVConsAMVES + TtlTimeMAO1 $*($ PConsAMVES/24)

RVConsAMVES $=$ RVConsAMVES + TtlTimeMAO1 * (PConsAMVES/24)

ArrivAMVES $=1$

-- PARA BMAO --

Move For tbRotas[14,1]

ConsAMVES $=$ tbRotas[14,4]

SVConsAMVES $=$ SVConsAMVES + ConsAMVES

RVConsAMVES $=$ RVConsAMVES + ConsAMVES 